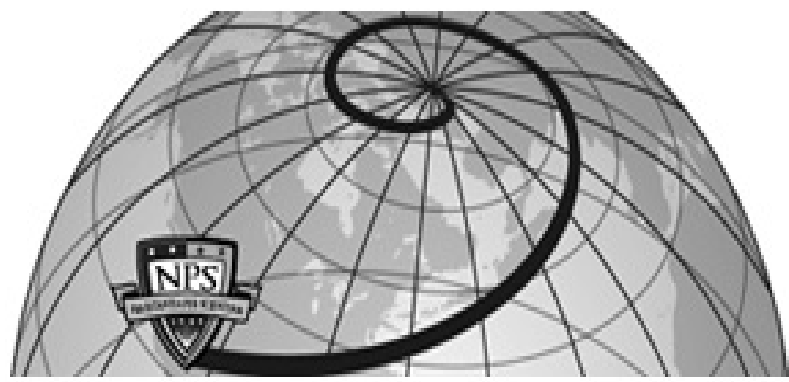

Calhoun: The NPS Institutional Archive DSpace Repository

\title{
An industry analysis of the MBA market and the competitive positioning of the GSBPP
}

Hager, Garrett W.; King, Thomas T.

Monterey, California. Naval Postgraduate School

https://hdl.handle.net/10945/10260

Downloaded from NPS Archive: Calhoun

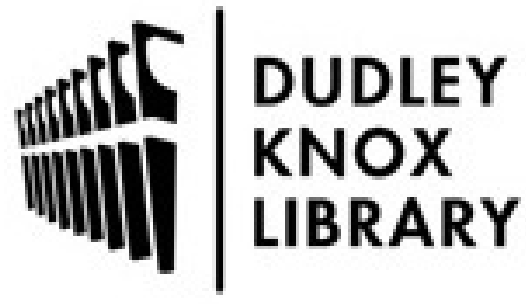

http://www.nps.edu/library
Calhoun is the Naval Postgraduate School's public access digital repository for research materials and institutional publications created by the NPS community. Calhoun is named for Professor of Mathematics Guy K. Calhoun, NPS's first appointed -- and published -- scholarly author.

Dudley Knox Library / Naval Postgraduate School 411 Dyer Road / 1 University Circle Monterey, California USA 93943 


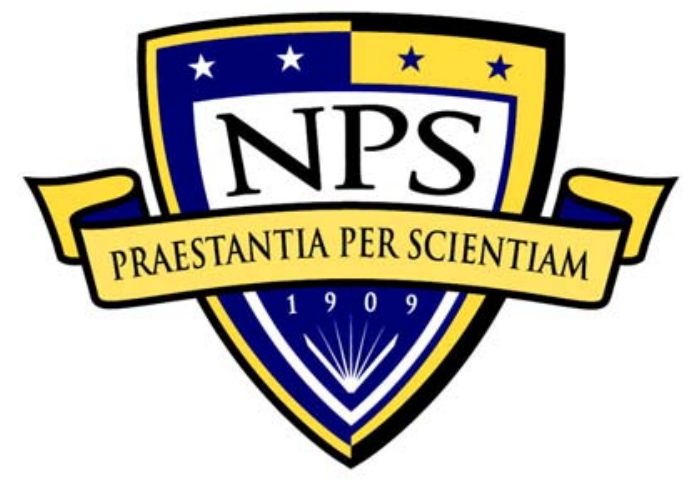

\section{NAVAL \\ POSTGRADUATE SCHOOL}

MONTEREY, CALIFORNIA

\section{MBA PROFESSIONAL REPORT}

An Industry Analysis of the MBA Market and the Competitive Positioning of the GSBPP

By: Garrett W. Hager

Thomas T. King

March 2007

Advisors: Peter Coughlan, William Gates 
THIS PAGE INTENTIONALLY LEFT BLANK 


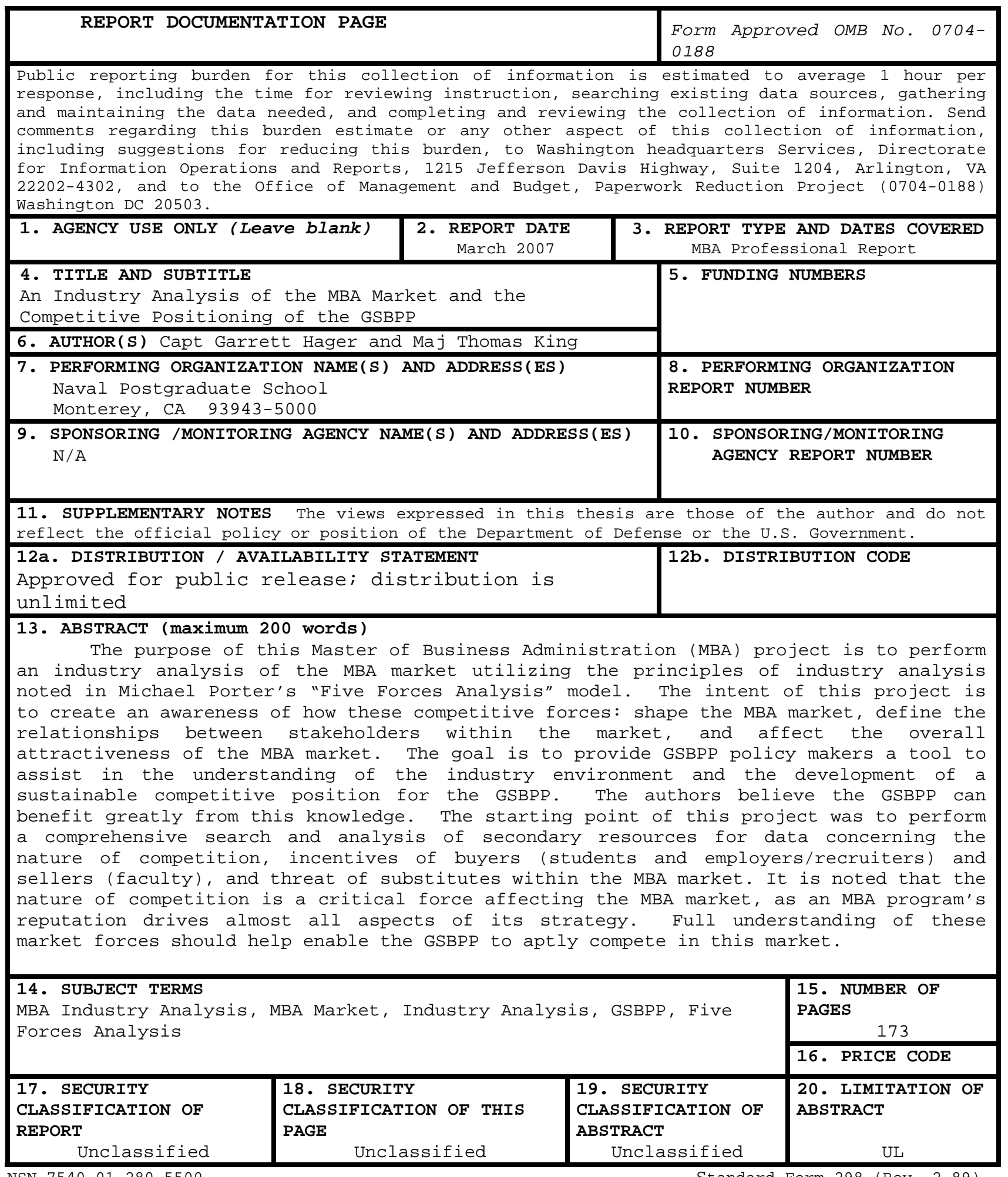

NSN 7540-01-280-5500

Standard Form 298 (Rev. 2-89)

Prescribed by ANSI Std. 239-18 
THIS PAGE INTENTIONALLY LEFT BLANK 
Approved for public release; distribution is unlimited

AN INDUSTRY ANALYSIS OF THE MBA MARKET AND THE COMPETITIVE POSITIONING OF THE GSBPP

Garrett W. Hager, Captain, United States Marine Corps Thomas T. King, Major, United States Marine Corps

Submitted in partial fulfillment of the requirements for the degree of

MASTER OF BUSINESS ADMINISTRATION

from the

NAVAL POSTGRADUATE SCHOOL

March 2007

Authors:

Garrett Hager

Thomas King

Approved by:

Peter Coughlan, Lead Advisor

William Gates, Support Advisor

Robert N. Beck, Dean

Graduate School of Business and Public Policy 
THIS PAGE INTENTIONALLY LEFT BLANK 


\section{ABSTRACT}

The purpose of this Master of Business Administration (MBA) project is to perform an industry analysis of the MBA market utilizing the principles of industry analysis noted in Michael Porter's "Five Forces Analysis" model. The intent of this project is to create an awareness of how these competitive forces: shape the MBA market, define the relationships between stakeholders within the market, and affect the overall attractiveness of the MBA market. The goal is to provide GSBPP policy makers a tool to assist in the understanding of the industry environment and the development of a sustainable competitive position for the GSBPP. The authors believe the GSBPP can benefit greatly from this knowledge. The starting point of this project was to perform a comprehensive search and analysis of secondary resources for data concerning the nature of competition, incentives of buyers (students and employers/recruiters) and sellers (faculty), and threat of substitutes within the MBA market. It is noted that the nature of competition is a critical force affecting the MBA market, as an MBA program's reputation drives almost all aspects of its strategy. Full understanding of these market forces should help enable the GSBPP to aptly compete in this market. 
THIS PAGE INTENTIONALLY LEFT BLANK 


\section{TABLE OF CONTENTS}

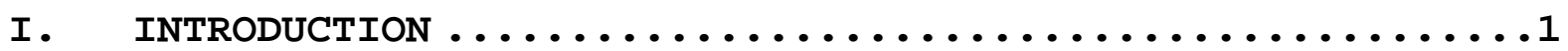

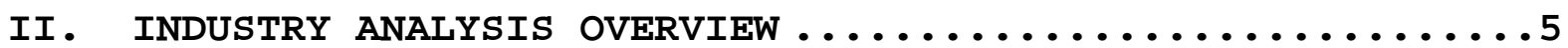

A. INTRODUCTION TO INDUSTRY ANALYSIS AND THE FIVE FORCES . . . . . . . . . . . . . . . . . . 5

B. COMPETITION ....................... 6

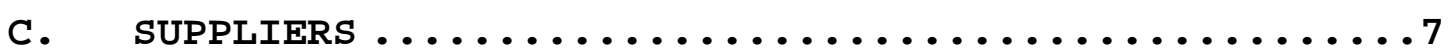

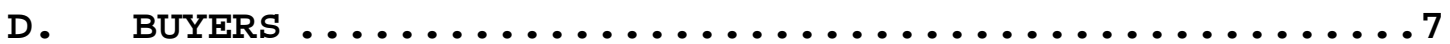

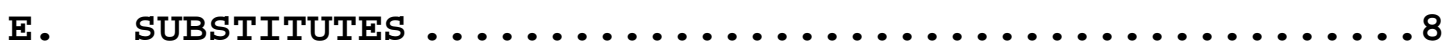

F. THREAT OF ENTRY . . . . . . . . . . . . . . 8

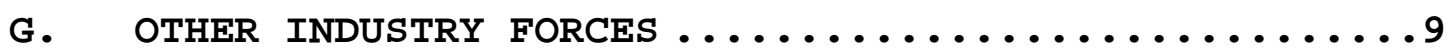

H. METHODOLOGY ........................ 10

III. COMPETITION . . . . . . . . . . . . . . . . . . . 13

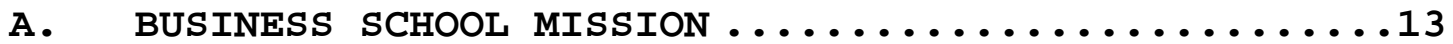

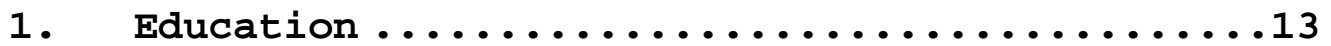

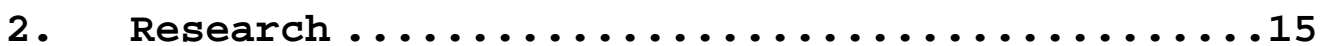

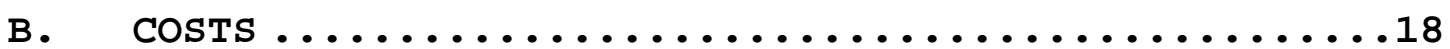

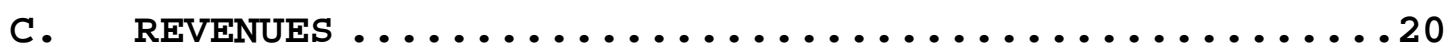

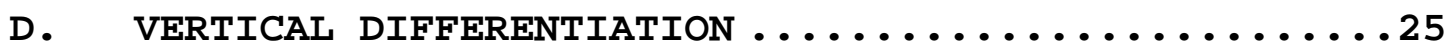

1. Rankings .......................... 25

2. Accreditation ...................... 38

E. HORIZONTAL DIFFERENTIATION . . . . . . . . . . . . 39

1. Specialization ... . . . . . . . . . . . . . 39

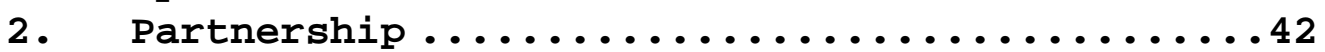

3. Regional Focus and Flexibility ...........42

F. ANALYSIS ..........................43

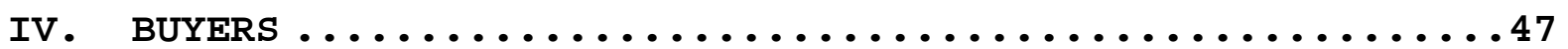

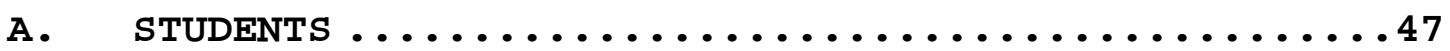

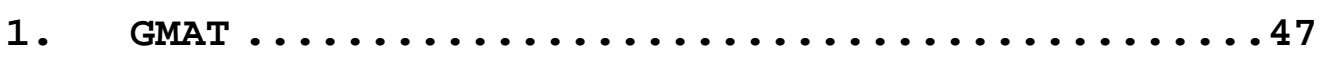

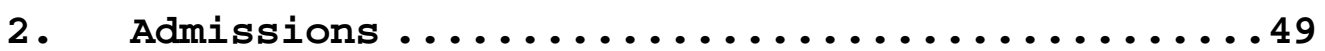

3. Program Selection Criteria .............51

4. Value of an MBA ...................55

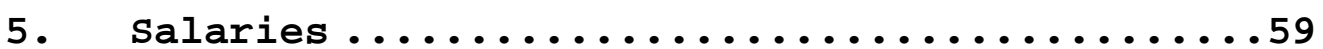

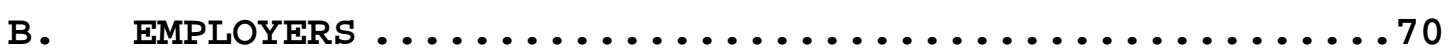

1. Who Hires MBAs? ................... 71

2. Why Do Employers Hire MBAs? .............73

3. From Which Schools Do Employers Hires MBAs? ..74

4. Why Do Some Employers Sponsor MBA Education? .76

C. ANALYSIS ...........................

1. Students ...................... 78

2. Employers ........................ 80

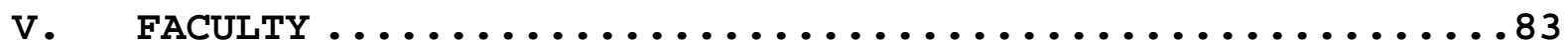


A. CATEGORIES OF BUSINESS SCHOOL FACULTY .........83

B. BALANCING TENURE-TRACK VS. "CONTINGENT" FACULTY . . .86

C. FACULTY CAREER PROGRESSION $\ldots \ldots \ldots \ldots \ldots \ldots \ldots \ldots 88$

D. FACULTY ROLES: TEACHING VS. RESEARCH $\ldots \ldots \ldots \ldots \ldots 93$

1. The Nature of Business School Research . . . . .997

E. BUSINESS FACULTY SHORTAGE: DEMAND EXCEEDS SUPPLY ..98

1. An Increasingly Foreign Candidate Pool . . . . 102

2. Competing with the Private Sector .........103

3. Confronting the Shortage ..............104

4. Turning to Non-Business and Contingent Faculty .......................106

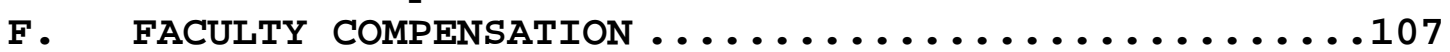

G. FACULTY CAREER CHOICE $\ldots \ldots \ldots \ldots \ldots \ldots \ldots \ldots \ldots 110$

H. FACULTY JOB SELECTION $\ldots \ldots \ldots \ldots \ldots \ldots \ldots \ldots \ldots 113$

1. Why Faculty Choose to Work at a Particular School .........................114

2. Relocating to New Positions ..........116

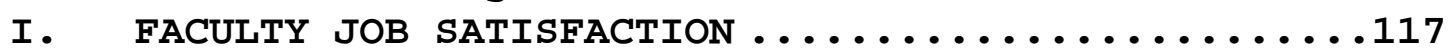

1. Lower Satisfaction Among Untenured TenureTrack Faculty .....................119

2. Sacrificing Family and Personal Life for the Academic Career ...................121

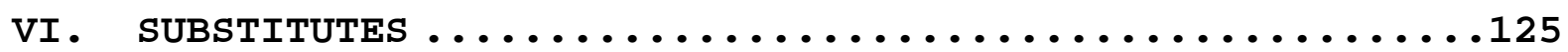

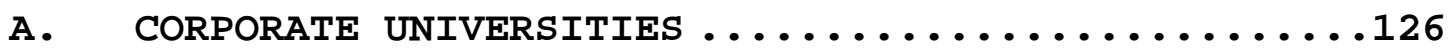

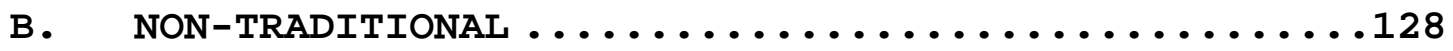

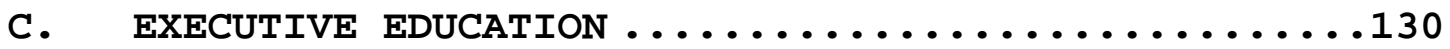

1. Degree Granting Executive Education ........130

2. Non-Degree Granting Executive Education .....131

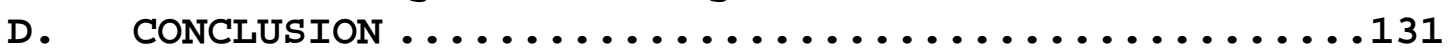

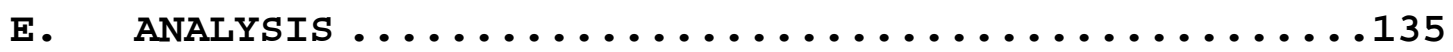

VII. ANALYSIS, CONCLUSIONS, AND RECOMMENDATIONS . . . . . . . 139

A. ANALYSIS OF GSBPP IN RELATION TO THE MBA MARKET

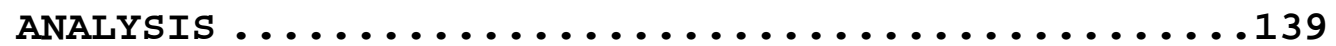

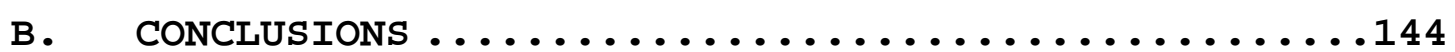

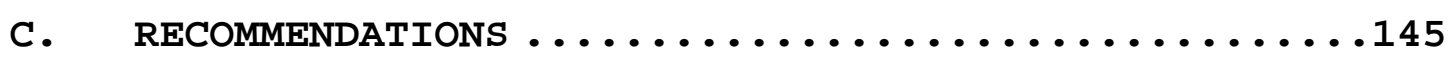

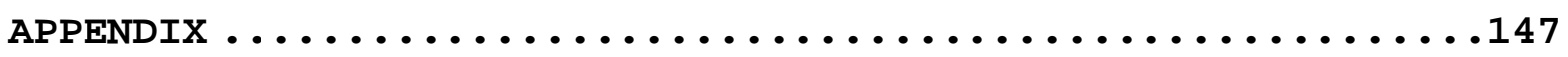

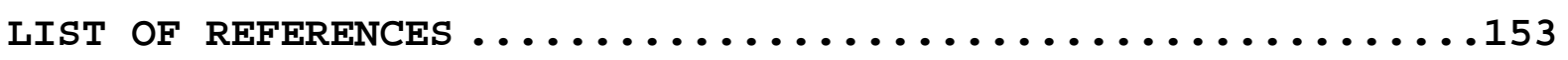

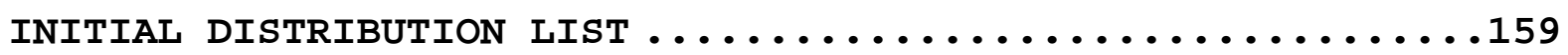




\section{LIST OF FIGURES}

Figure 1. MBA Representative Core Course Requirement......14

Figure 2. Expense Components for the Harvard Business School, FY $2005 \ldots \ldots \ldots \ldots \ldots \ldots \ldots \ldots \ldots \ldots \ldots$

Figure 3. Revenue Components for the Harvard Business School, FY $2005 \ldots \ldots \ldots \ldots \ldots \ldots \ldots \ldots \ldots \ldots \ldots 21$

Figure 4. Components of Revenue for the University of Wisconsin Business School................22

Figure 5. Criteria Used by Publications to Rank MBA

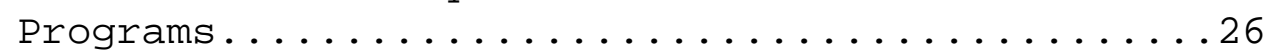

Figure 6.

Figure 7.

Figure 8.

Figure 9.

Publication's Top Ten MBA Rankings.........28

The "Virtuous Cycle" of High Rankings.........36

The "Vicious Cycle" of Low Rankings............37

Figure 10. GMAT Data, Then vs. Now................48

Figure 11. School Selection Criteria...............53

Figure 12.

Figure 13. Importance of School Selection Criteria........54 Top Ten standardized Ratings of Specific Criteria within Key Aspects................54

Figure 14. Overall Numbers.......................... 55

Figure 15. Impact of Top 10 Ranking. . . . . . . . . . . 56

Figure 16. Impact of Top 50 Ranking................56

Figure 17. Value of the MBA Program................58

Figure 18.

Figure 19. Satisfaction with Aspects of the MBA Degree.....59 Average Base Salary among MBA Grads who Received/Accepted Offer of Employment........61

Figure 20. Estimated Starting Salary for New Hires........61 Salaries and Bonuses for Respondents who Accepted a Job offer, by Work Experience.......62 Figure 21. Method of Financing Graduate Management Education.........................63

Figure 22. Right Decision to Pursue the MBA Degree......66 Figure 23. Motivation to Pursue a Graduate Management Education.........................64

Figure 24. Reservations about Pursuing Graduate Management Education..........................65

Figure 25. Overall value of the MBA Degree...........66 Figure 26. Figure 27. Satisfaction with the MBA Degree..........67 Figure 28. Figure 29. Figure 30. Figure 31. Figure 32 . Level of Improvement in Skills and Abilities...668 Job Level........................68 Career Switching vs. Career Enhancement.......69 Job Functions.......................69 Industry Group Pursued for Employment.........70 Number of Job offers...................71 
Figure 33. Corporate Recruiters Survey $2006 \ldots \ldots \ldots \ldots \ldots .74$

Figure 34. Number of Schools which Company Visits to Recruit MBAs (GMAC, 2006a)................76

Figure 35. Corporate Reimbursement and Sponsorship Programs Among Firms That Hire MBAs (GMAC,

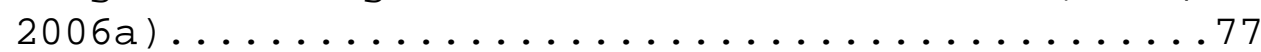

Figure 36. Sources of Job offers................77

Figure 37. Classification of Higher Education Faculty.....83

Figure 38. Faculty Employment Status by Institutional Category, Fall 2005....................85

Figure 39. Trends in Faculty Employment Status, All Colleges \& Universities, 1975-2005..........86

Figure 40. Generalization of the Tenure-Track Career Ladder.............................89

Figure 41. Generalization of the Non-Tenure-Track Career Ladder...........................92

Figure 42. Distribution of Faculty by Rank and Institutional Category, 2005-2006...........93

Figure 43. Balance of Faculty Interest between Teaching and Research.......................94

Figure 44. Research Publications of Full-Time Faculty Members, $2001-2002 \ldots \ldots \ldots \ldots \ldots \ldots \ldots \ldots . \ldots . \ldots 6$

Figure 45. Degrees Conferred in Business and Management in the U.S. (1969-2004).....................100

Figure 46. Doctoral Career Choices of Business and Management Doctorates (2004)...............104

Figure 47. Average 9-Month Salary by Business Field and Rank (2005-06) (\$ in $000^{\prime} s$ )................109

Figure 48. Top Reasons Faculty Pursue an Academic Career..111 Figure 49. Importance of Factors in Accepting a Business School Faculty Position ( 7 point scale, 7=extremely important, 1=not at all important)..115 Figure 50. Top Reasons Faculty Are Satisfied with a Particular Academic Position..............119 Figure 51. Top Sources of Stress among Faculty Members, Compared by Gender.....................

Figure 52. Impact of Program Type................. Figure 53. Overall Value of the MBA Degree, by Program Type........................... 134 


\section{ACKNOWLEDGMENTS}

The authors would like to acknowledge our wives and children. Without their support, we could not have accomplished this milestone in our academic careers. We would also like to acknowledge the help of Professor Peter Coughlan. Without his tremendous effort, motivation, and dedication, we would not have completed such a worthwile effort. A special thanks also goes out to Professor William Gates for his tireless dedication to this project and to us. Thank you all. 
THIS PAGE INTENTIONALLY LEFT BLANK

xii 


\section{INTRODUCTION}

Traditional business schools face threats to their competitive positioning as the educational industry becomes more diverse. The ability of educational institutions to remain competitive is contingent upon their ability to correctly identify the factors that influence the industry and to adjust their strategy accordingly. Specifically, The Naval Postgraduate School's (NPS) Graduate School of Business and Public Policy (GSBPP) must develop a strategy to provide its customers and suppliers with greater value than the alternatives provided in a growing management business education industry.

For its customers, providing greater value refers to GSBPP'S ability to provide the greatest "bang for the buck" in terms of benefits relative to costs. With so many competitors in the market, there is no guarantee that GSBPP will perpetually continue to provide best value. If at any point the school no longer provides the best value, the Department of Defense (DoD) will find other sources of supply for its graduate education requirements.

The concept of best value is relative. Understanding how GSBPP relates to its environment is critical to identifying the activities in which the school should engage. However, this first necessitates a clear definition of the environment. This thesis will rely primarily upon articles written by Michael Porter. In his article "How Competitive Forces Shape Strategy," Porter defines an industry as a group of firms that market products which are close substitutes for each other. 
In the article, Porter identifies the five primary competitive forces. These forces are the elements that this thesis will analyze with relation to the graduate business education industry as a whole and then as to how GSBPP's position within the industry allows it to compete.

The purpose of this MBA Graduate Project, in particular, is to conduct an industry analysis of the notional market for Master of Business Administration (MBAs) degrees. In this endeavor, an identification and analysis of the market forces affecting the MBA market was conducted to determine what type of competitive positioning is necessary to be successful. By assessing these market forces, or any market forces for a given industry, business strategists provide insight that allows them to understand the competitive positioning of their organization within that industry. This knowledge enables them to make informed decisions about the strategic direction of their company.

Too often, strategic decisions are made in absence of this information. This leads to a "marketing myopia" of sorts that usually appears in a company's focus only on its buyers when making decisions regarding price, product, promotion, etc. This can cause an organization to make strategic blunders because they fail to recognize how their decisions affect relationships with suppliers. It can also cause them to give up valuable market share to its primary competitors. Another problem that this ignorance can cause is inadvertently increasing demand for substitutes to its products. Either of these situations can cause loss of money through diminished sales or increased input costs. 
These principles not only apply to the private sector, but also to the public and non-profit sectors. The same valuable lessons about understanding the industry in which an organization competes and of an organization's positioning within that market are universal. Even though you might not earn a profit, there are lessons to be learned about the environment in which you operate.

In this case, the five forces approach will be employed to analyze attributes of the market for graduate business education, which will ultimately be used to evaluate the competitive position of the Naval Postgraduate School's (NPS) Graduate school of Business and Public Policy (GSBPP). 
THIS PAGE INTENTIONALLY LEFT BLANK. 


\section{INDUSTRY ANALYSIS OVERVIEW}

\section{A. INTRODUCTION TO INDUSTRY ANALYSIS AND THE FIVE FORCES}

Michael Porter's articles, "How Competitive Forces Shape Strategy" and "Note on the Structural Analysis of Industries," provide guidance on how to evaluate the competition in any industry. Porter maintains, "The intensity of competition in an industry is neither a matter of coincidence or bad luck." He argues that the nature of competition is based on the economics of the industry and five basic competitive forces, which are illustrated in exhibit $A$.
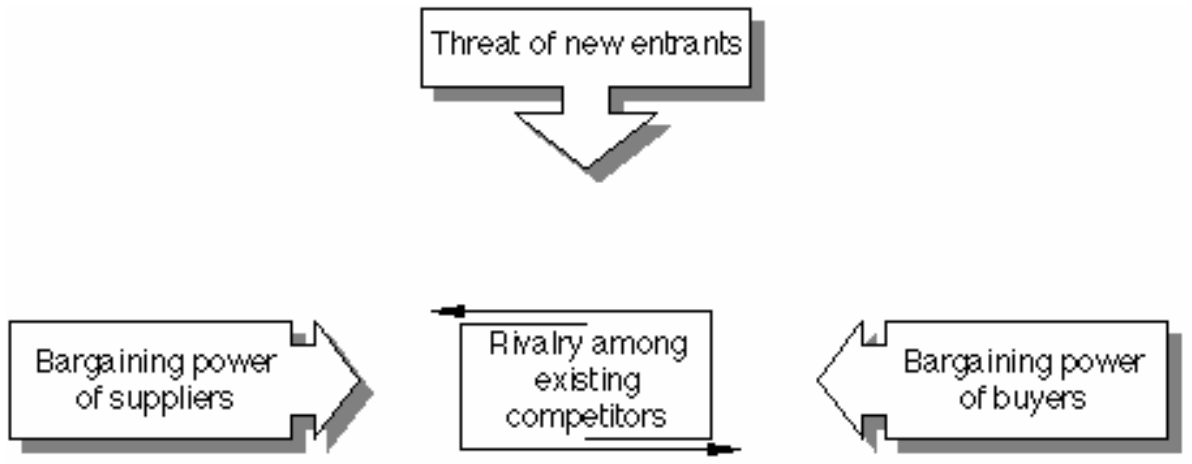

Both articles provide reference for the necessary background, which will be the basis for analyzing the business school industry. Prior to delving into the specifics of the B-School industry, it is useful to provide 
some background information and definitions on Porter's five forces to better understand the common terms and ideas.

The two Porter articles highlight the importance of examining the five forces for understanding what causes an industry to behave in a certain way. The contention is that evaluation of these forces will provide insights into the prospects for long-range profitability. Each of the forces is discussed below to offer a commonly accepted definition and enough background to allow the layman to understand the concepts in not only a general context but in the specific application to B-Schools.

\section{B. COMPETITION}

The first of the five forces influencing industry economics is the rivalry among existing competitors in a market. Porter refers to this as "jockeying for position." The intensity of the rivalry among competitors is related to the following factors:

- Number and relative size of competitors

- Level of industry growth

- Degree of differentiation

- Relative magnitude of fixed costs

- Level of exit barriers

- Diversity of strategies employed by rivals 


\section{SUPPLIERS}

Supplier power is a second force to be considered. Suppliers who have advantages of limited availability of their product may raise prices or reduce quality in an effort to increase their profits. Actions such as these diminish the profit potential of competitors in a given industry if there is no alternative. Porter suggests that a supplier group is powerful if:

- It is dominated by few companies and is more concentrated than the industry to which it sells.

- The input supplied is unique, differentiated or requires significant switching costs.

- Suppliers pose a credible threat of forward integration.

- Industry is not an important customer of the supplier group.

\section{BUYERS}

The buyer group constitutes the third industry force and this group is powerful if:

- It is concentrated or purchases in large volume.

- Products are standard or undifferentiated.

- Products it purchases from the industry in question form a component and represent a significant fraction of cost. 
- The buyer group earns low profits (increasing the incentive to lower its purchasing cost)

- Product is unimportant to the quality of buyers' products or services.

\section{E. SUBSTITUTES}

Substitutes are the fourth force. They are products that can be used as alternatives and provide similar utility at less price. The key to substitutes is the customer's willingness or ability to trade off differentiated functionality for cost. If an industry fails to differentiate in a way that prohibits the tradeoff, the substitute will place downward pressure on industry prices.

\section{F. THREAT OF ENTRY}

Threat of entry is the final force addressed. The importance of this force is based on the premise that new competitors in an industry bring added capacity. The added capacity will provide a downward pressure on prices as competitors fight for increased market share. Entry barriers, however, can be high. These high barriers increase the risk for the new entrant and can deter entry if the promise of profit is not great enough to outweigh the risk. Porter cites six major barriers to entry:

- Economies of Scale - force entrants to enter on a large scale or accept a cost disadvantage

- Product Differentiation - implies finding a position to overcome entrenched customer loyalties 
- Capital Requirements - need for large sums of upfront capital which may not be recoverable

- Cost Disadvantages independent of size advantages attained through learning curve, proprietary technology, geographic location, etc.

- Access to distribution channels - new entrants must find room or displace current competitors to get their product to market

- Government policy - industry regulations, controls, accreditation and licensing requirements may prohibit entry to potential competitors.

\section{G. OTHER INDUSTRY FORCES}

While Porter's approach identifies and analyzes the five key forces in any market, there may also be other forces that may not fit neatly into one of these five categories but may nonetheless significantly affect any given market's economics and structure. It is up to the individual organization to investigate their respective markets thoroughly to determine what other forces are out there. Forces could range from external stakeholders, such as the media and government, to organizations that produce complements that impact the demand for the primary products in that market. In any case, for each force or stakeholder group, it is important to understand its degree of leverage over the organization as well as its incentives as they relate to its interaction with the organization.

The need to look beyond the basic five forces is observable in the personal computer market, where 
complementors play a key role. Manufacturers of peripheral devices, such as printers, monitors, and software, do not compete with personal computers. They do, however, interact with the computer manufacturers by either collaborating with them or with their competition. By making devices for use on or with the personal computers, they enhance the desirability of the computers themselves, and in this way their products serve as complements to the personal computer industry. It is important for the computer manufacturers to consider this when determining their competitive strategies within the computer market. If they overlook the manufactures of the peripherals, they could alienate themselves and drive them to form strategic partnerships with other firms in the market. And, if they want to elicit the help of the peripheral manufacturers, they need to consider what types of incentives they are prepared to offer them to earn their loyalty. This shows that there are more forces at play than just the competitors, buyers, suppliers, substitutes, and potential entrants. It is important that a thorough investigation and analysis of the market and all key stakeholders be conducted so that no stakeholder is left out.

\section{H. METHODOLOGY}

The methodology in applying the five forces analysis to the MBA market was to scrutinize each of the "five forces" to see exactly how each would be utilized to understand the effects they collectively have on the economics and structure in the market for MBA education. We conducted an in-depth search of secondary research to gather information to answer questions pertaining to each of the five forces. Upon completion of our research, we 
concluded that the major forces that affect the MBA market were competition between business schools, buyers of business education including both students and employers, faculty as the key suppliers to the industry, and substitutes in the forms of alternative means of delivering graduate business education. Because the factors contributing to barriers to entry in the industry primarily consist of factors, (such a building a reputation) which were also relevant to the nature of competition, potential entrants were not considered in an individual category but were addressed as part of our analysis of competition. The following chapters provide the results of our research. 
THIS PAGE INTENTIONALLY LEFT BLANK 


\section{III . COMPETITION}

In 2004, the AACSB conducted a Strategic Management Survey of member schools. In that survey, business school deans reported that the greatest pressures on their job came from managing faculty issues (cited by $74 \%$ of respondents), identifying and pursuing new funding sources (45\%), and distinguishing their business school from competitors (24\%). (Fairbank, Libanca, \& LeClair, 2005) These results demonstrate the diverse elements of competition in the MBA market and illustrate why competitive rivalry is a critical important market force in this industry. They also highlight the areas of the competition that are the most prominent within this category: cost, revenues, and reputation.

\section{A. BUSINESS SCHOOL MISSION}

The business school mission includes two primary components: education and research.

\section{Education}

A typical core MBA curriculum can be seen in Figure 1. (Lathroum, 1998) Among the top 10 MBA programs, the range of core (i.e., required) courses ranges from as few as 6 to as many as 16, with an average somewhere around 11 . The total MBA courses that students must complete at these programs range much more narrowly from 19 to 23. While course offerings at the different schools are generally similar (both inside and outside the core), the experiences of different MBA students can vary widely based on the elective courses they choose to take. Moreover, the course offerings and content appear to be important to students given that a factor analysis conducted in 2006 showed that 
the MBA curriculum has a profound impact on the perceived value of the MBA. (Syed, 2006)

Figure 1. MBA Representative Core Course Requirement

\begin{tabular}{|l|l|l|}
\hline $\begin{array}{l}\text { Management and } \\
\text { Organization }\end{array}$ & Financial Management & Economics \\
\hline Strategic Management & Financial Accounting & Microeconomics \\
\hline Human Resource Management & $\begin{array}{l}\text { Managerial } \\
\text { Accounting }\end{array}$ & Macroeconomics \\
\hline Organizational Behavior & Finance & \\
\hline Management Communication & & Other \\
\hline Leadership & & Business Ethics \\
\hline Quantitative Skills & Marketing & Business Law \\
\hline Operations Management & Marketing & \\
\hline Statistics & & \\
\hline Decisions Analysis & & \\
\hline
\end{tabular}

While business schools consider it their mission to educate students for their entire career, they are under intense pressure from the business community to focus less on higher level long-term education and, instead, focus on short-term training on business practices. Other professional schools have faced this battle between education and the profession's demand for vocational training. Law schools, for instance, have said "No" to the profession's suggestions that they should be providing more hands-on training and practical application skills that could help them pass the bar exam. Law schools have instead opted for a model of education that prepares 
students for a career in law vice their next job. (Dulek, 1992)

James Howell, co-author of the 1959 Gordon-Howell report, agrees with this logic, arguing that:

A business school has to serve the profession, but that doesn't mean that it should always do what the profession wants it to do. Its obligations are to its students and to the profession as it's emerging, not necessarily as it exists today. I think it's important that business schools stay some distance away from the business community. Their primary responsibility is not to today's business community; it's to the business community of the future, and, in a more abstract sense, to society. You're trying to serve society through professional education... (Dulek, 1992)

This speaks against the call for curriculum reform that typically leads to less vigorous, vocational type courses that focus on current trends in business and primarily teach students skills to be successful at their first job vice techniques that will equip them for a successful career. (Dulek, 1992)

\section{Research}

In 1959, the Gordon-Howell Report was published as the culmination of a series of reports and papers focused on surveying professional business education. This report deduced that the American business education system was nothing more than a collection of trade schools that operated without reliance on any strong scientific foundation whatsoever. (Dulek, 1992) overall, business schools were poorly regarded both on their own campuses and in business circles.(Dulek, 1992) Herb Simon, a Nobel laureate, concluded, "Accurately or not, we perceived American business education at that time as a wasteland of 
vocationalism that needed to be transformed into sciencebased professionalism, as medicine and engineering had been transformed a generation or two earlier..."(Dulek, 1992)

One of the first institutes to offer science-based graduate business education was the Graduate school of Industrial Administration (GSIA) at Carnegie Tech in 1949. Staffed largely with economists from the University of Chicago, GSIA produced an impressive portfolio of research and doctoral students.(Dulek, 1992) GSIA's first dean, Lee Bach, wrote in 1951,

...business administration is a new profession. It still operates heavily on rules of thumb and hunches, often unnecessarily so. It is a profession that is growing up rapidly. A crucial part of that growth must be the amassing of careful scientific analysis and research to lay bare what is hearsay in management, what is fundamental skill, and what is transient practice. I am personally convinced that careful, fundamental research in the management fields over the next half century can and will vastly improve our present knowledge and skills.(Dulek, 1992)

Echoing Mr. Bach's concerns, the Gordon-Howell Report provided a recipe to change the perceptions held of the business schools:

Collegiate business education should educate for the whole career and not primarily for the first job. It should view the practice of business professionally in the sense of relating it to what we have in the way of relevant, systematic bodies of knowledge. It should emphasize the development of basic problem-solving and organizational skills and socially constructive attitudes rather than memory of facts or training in routine skills. (Dulek, 1992) 
By incorporating the suggestions in the Gordon-Howell Report, Graduate Business Education took a turn. Leading business schools began investing heavily in science-based research faculty and doctoral programs to shift their focus from training to education. (Dulek, 1992) They expanded heavily into doctoral education as well. Schools began to recognize that having doctoral students serves three purposes: (1) doctoral students enhance faculty research efforts by assisting them and co-authoring topics; teaching doctoral seminars motivates faculty to perform more and better research; and (3) most importantly, "doctoral students are the researchers and teachers of future generations." (Dulek, 1992)

Having shifted the focus from training to education and placing a greater emphasis on research, business schools completed a drastic turnaround. This turnaround helped to improve the perception of the MBA. MBAs boomed from 3,200 in 1955-56 to over 102,000 in 1997-98; an annual compound growth rate of about 8.4 percent. (Dulek, 1992) In addition, business school faculties were publishing in prominent international social science journals. (Dulek, 1992)

Known for their research skills and analytical backgrounds, business schools added economists to their staff. This new breed of faculty used its systematic bodies of knowledge to create new and inspiring curricula. courses that relied on vocational, experience-based principles were replaced by courses that focused on problem solving and organizational skills.(Dulek, 1992) Concepts such as the capital asset pricing model, the efficient markets hypothesis, game theory, linear programming models 
for constrained resource allocation, and option pricing and risk management, which now serve as some of the staples of MBA curricula, came from basic research conducted decades earlier. As one scholar noted:

The latter practical application [of these basic research findings] followed in much the same way as nuclear power followed the basic theories of high-energy physics and Einstein's theory of relativity, or as watson and Crick's basic research into the double helix structure of DNA led to today's extensive applied research in genetic engineering. Basic theoretical research precedes applied research. Powering the boom of business education in the $1980 \mathrm{~s}$ and $1990 \mathrm{~s}$ was the highly abstract, then-impractical basic research of the 1960s and 1970s. (Dulek, 1992)

This emphasis on fundamental, theoretical research caused a revolution in business education. Instead of teaching facts about business, schools began to emphasize learning to think about business problems and situations. Business schools began to educate students vice train them. (Dulek, 1992) Now, in the wake of the successful shift from vocation to education, MBAs from top ranked schools are highly sought after by businesses, as noted professor James Howell is quoted as saying, "because of the theoretical, abstract intellectual approach that they bring. They are the ones who come in with new ideas and see problems in different ways." (Dulek, 1992)

\section{B. $\quad$ COSTS}

A surprising reality regarding the economics of graduate business education was expressed by Kenneth Dunn, dean of Carnegie Mellon's Tepper School of Business, when he observed, "You lose money on every MBA ... My guess is that no top MBAs cover their cost, because you need 
outstanding faculty to attract the students; to attract outstanding faculty, you need money to finance their research." (Economist Staff, 2004)

Figure 2 demonstrates the types of costs that a typical MBA program can expect to incur during normal business operation. This figure was taken from the Annual Report of the Harvard Business School, however the relative breakdown of expenses is typical of major business schools. It is interesting to note that the salaries and benefits for faculty account for the majority of the costs, comprising 50 percent of the total expenditures.

Figure 2. Expense Components for the Harvard Business School, FY 2005

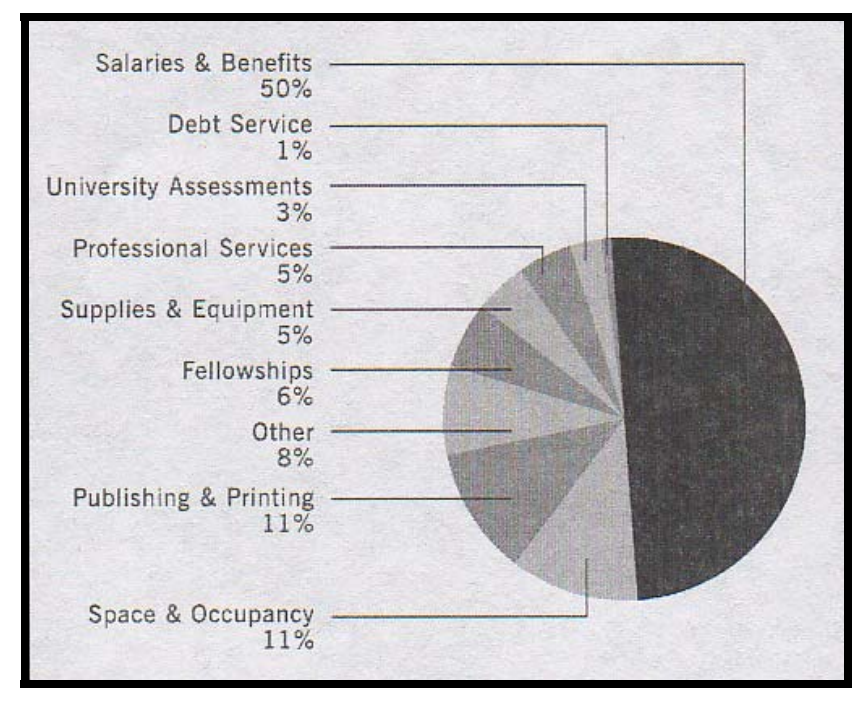

The significant costs associated with graduate management education have left room for competitive entry by low cost providers. A decade ago, if you had asked business school deans what they thought would be the stiffest competition to residential MBA programs, they might have said private consulting firms or corporate 
universities. However, they are now facing the reality that they must compete with the low-cost providers who can turn a profit because they are not burdened with the high fixed costs of the "bricks and mortar" university. These smaller for-profit companies are not tied to traditional campuses like the high-cost providers are. Thus, they can reach markets that are too costly for the traditional MBA programs. (Bisoux, 2004)

The problem facing the traditional high-cost management education providers is that to serve a shifting customer demographic, business schools must offer students real-world experience, greater access to information, expanded use of technology, a higher level of skill development, and more sophisticated global perspectives. (Westerbeck, 2004) They are also forced to provide new services, including career placement assistance and convenient hours. At the same time, they are trying to fund new facilities, building renovations, and upgrades to technology. This is a costly set of requirements that require more resources and better-educated faculty. The combination of these costs exceeds what tuition alone can cover.

\section{REVENUES}

Today, MBA programs are facing an increasingly complex funding scenario as traditional sources of funding are shrinking, requiring deans to spend more energy considering how to raise capital. As Newman, Couturier, and Scurry (2004) observe, "the search for truth" in higher education institutions "is rivaled by a search for revenues." (Gappa, Austin, \& Trice, 2007) At the same time, competition for faculty and students is intensifying, leading to higher 
salaries and more money invested in recruitment. (Fairbank, Labianca, \& Leclair, 2005) Where is the money coming from?

Despite what one might think, the majority of money isn't coming from MBA tuition. Most traditional MBA programs, as well as universities in general, recognize that tuition alone will not cover the rising costs of employing faculty and paying for their research, much less all of the other costs previously discussed. Figures 3 and 4 provide a breakdown of revenues for a representative private (Harvard Business School) and public (University of Wisconsin) business school.

Figure 3. Revenue Components for the Harvard Business School, FY 2005

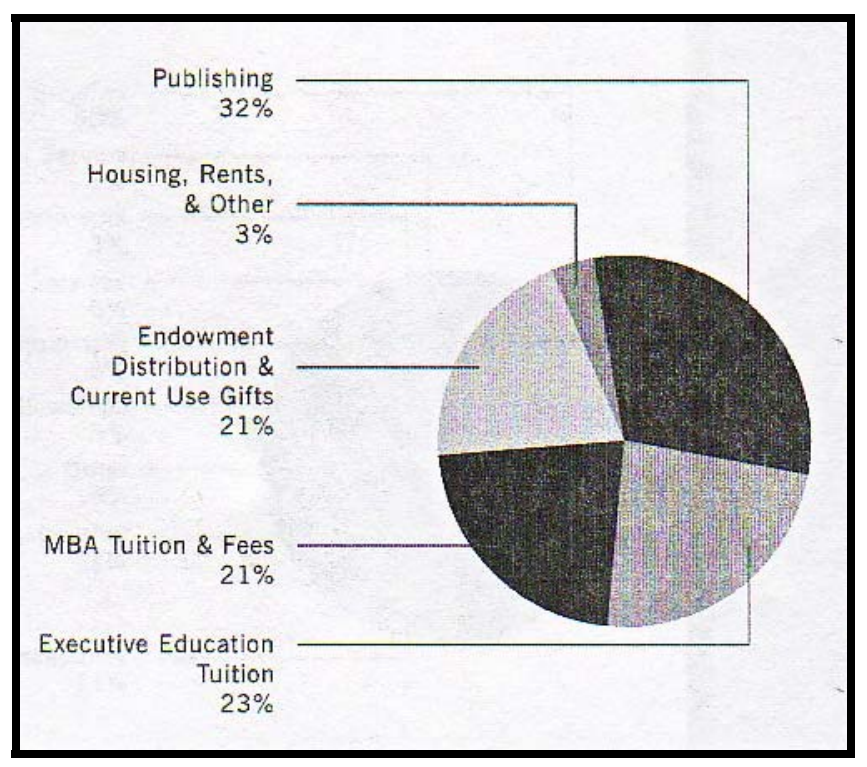

At Harvard, tuition and fees only comprise 21 percent of the total revenue; at Wisconsin, tuition and fees only generate 37 percent of revenue, and that is with state aid subsidizing tuition. These figures show that the vast majority of universities have to seek out other sources of revenue to stay out of the red. Harvard and Wisconsin each 
rely heavily on private funding and endowments, 21 percent and 21.9 percent respectively, to continue to operate.

Figure 4. Components of Revenue for the University of Wisconsin Business School

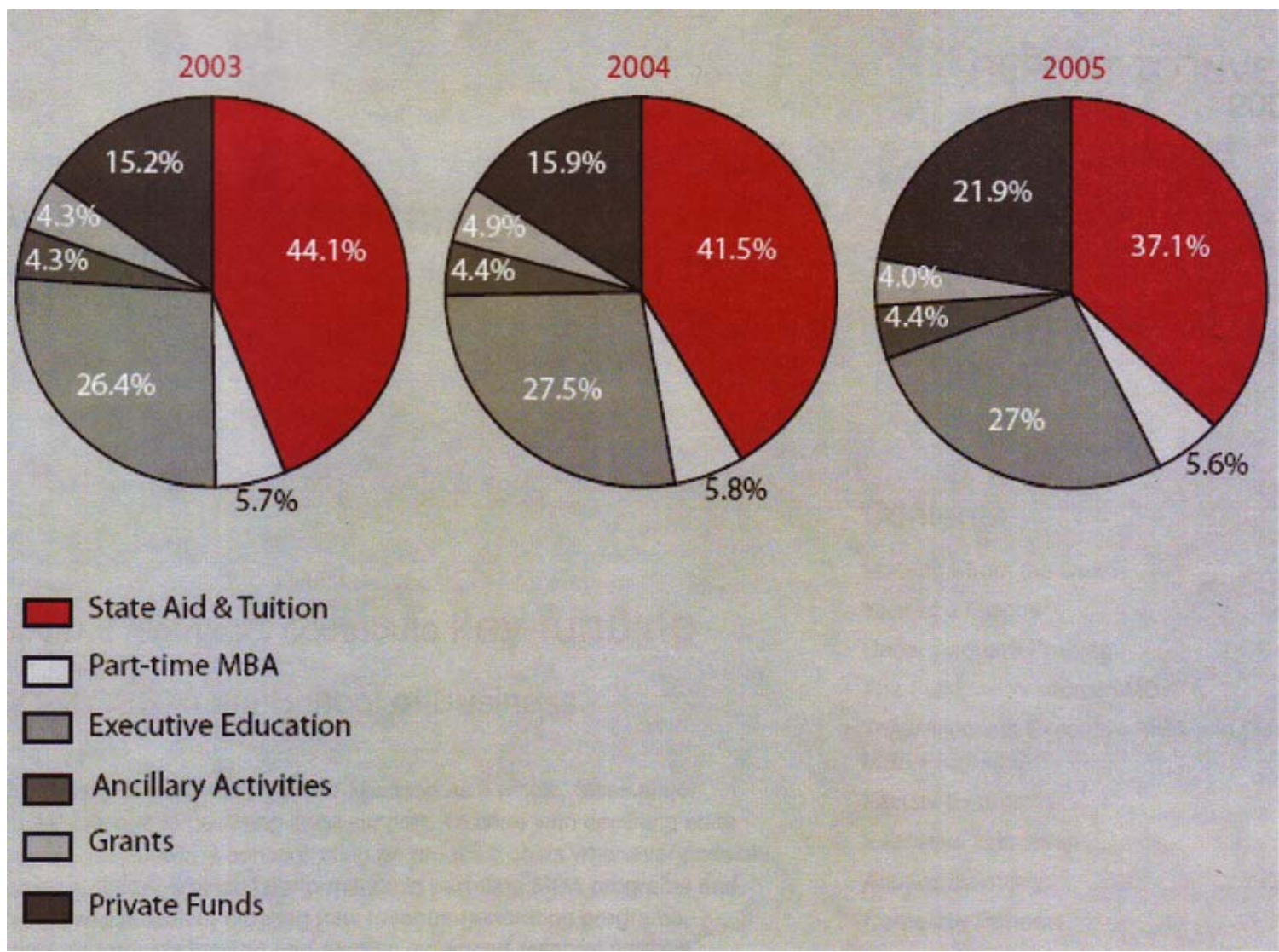

In today's market, most schools are forced to rely on endowments, donations from alumni, and contributions from companies with a vested interest in the institution's success. (Economist Staff, 2004) Melvin Stith, dean of Florida State University's College of business, says, "Most [public] universities would say they get 50 cents on the dollar from state appropriations and make up the rest through philanthropy." (MBA.com, 2005a) GMAC's Selections recently studied the naming gifts that business schools 
received between 1998 and 2003. Of this group, 13 schools received between $\$ 25$ million and $\$ 62$ million in donations.(Fields, 2006) Since November 2001, BizEd has reported gifts of $\$ 20$ million or more to six business schools, in addition to those cited in the selections study. The largest naming gift was $\$ 100$ million and awarded by Stephen $M$. Ross to what is now the University of Michigan's Ross School of Business.(Fields, 2006)

In the same article, BizEd reported 11 gifts or grants ranging from $\$ 5$ million to $\$ 17$ million, and 37 gifts or grants ranging from $\$ 1$ million to $\$ 5$ million. (Fields, 2006) Of the 387 AACSB-accredited schools that responded to a 2002-2003 survey by AACSB Knowledge Services, almost 10 percent had endowments exceeding $\$ 50$ million. Sixty percent, however, had endowments of $\$ 5$ million or less.(Fields, 2006) one study shows that philanthropic contributions to both public and private universities averages somewhere around \$24 billion a year. (Tyson, Spring 03) These studies clearly demonstrate the major role that gifts and endowments play in the school's financial well-being.

These philanthropic donations do more than just fund the business programs. In some cases, these gifts can propel a program into the rankings. This can have a profound effect on strategic growth. The Sam walton College of Business, after receiving a mega-gift of $\$ 50$ million, began to rise in U.S. News and World Report's business school rankings and currently ranks as a top-50 school. Two years after Notre Dame's Mendoza College of 
Business received a $\$ 30$ million gift, it vaulted up the rankings, breaking into Business Week's top-30 in 2002. (Tyson, Spring 03)

It seems that the only educational programs that are generating positive cash flow at business schools are the non-traditional MBA programs (i.e. part-time, executive education, and other types of hybrid MBAs). (Bisoux, 2006) At Harvard, executive education tuition contributed 23 percent to the total revenue received in 2005. At Wisconsin, executive education was 27 percent of their total revenues in 2005 .

Some traditional Business schools have also added the option of marketing their services to the external customers. They can sell their instruction, information, and consulting services to other outside organizations, thus providing them some degree of independence from university and state support in meeting their budget shortfalls. (Bisoux, 2004) Wisconsin attributed 21.9 percent of their 2005 revenues to these activities. This puts the advantage in favor of the larger, private schools that have a lengthy pedigree of alumni with resources to donate back to the institutions.

Given the difficulties that these traditional programs have generating income, it is not surprising that the state funded institutions are facing increasing competition for financial aid from their respective states. With more and more institutions seeking monetary relief, the supply of money is shrinking. In fact, one AACSB publication noted that "23 states approved spending plans for higher education for the 2003-2004 fiscal year. Each of these plans allocated less funding than in the previous year. 
Thirteen states made similar cuts in 2002-2003, and five states did so in 2001-2002." (Fields, 2006) It is evident that this trend of decreasing funding does not bode well for the smaller, government funded programs. With this glib picture of the MBA marketplace, one wonders why a university would offer the degree. In fact, in many cases, offering a traditional MBA degree represents more of an investment in the school's reputation than an effort to make a profit. (Bisoux, 2006)

\section{VERTICAL DIFFERENTIATION}

\section{Rankings}

In 1988, Business week published its first rankings of business schools. Since then, four other sources have been publishing rankings: The Wall street Journal, Financial Times, U.S. News and World, and Forbes. In determining rankings, these publications take into account student surveys, a survey of corporate recruiters, faculty research, average undergraduate GPA, average GMAT scores, a survey of business school deans, acceptance rate (selectivity), starting salary and bonuses of graduates, placement percentage, salary increase for graduates, career progression of the students, diversity and international exposure, and alumni ratings. See Figure 5 for a complete breakdown of which publications use what criteria for their rankings. The publications take a combination of these statistics and formulate their rankings. Students rated The wall street Journal, which ranks MBA programs exclusively on recruiter surveys, as the publication with the most credible rankings. (Schoenfeld \& Bruce, 2005)

An interesting fact about rankings is that, because of the differences in how they compile the rankings, the 
publications do not always agree on how the MBA schools rank. For instance, when The Wall street Journal's ranking first came out in 2001, it had stanford at 45, whereas Business week had Stanford at 11, and US News had Stanford at number 1. (Mast, 2001)

Figure 5. Criteria Used by Publications to Rank MBA Programs

\begin{tabular}{|c|c|c|c|c|c|}
\hline \multirow{2}{*}{ Criteria } & \multicolumn{5}{|c|}{ Publication } \\
\hline & $\begin{array}{c}\text { Business } \\
\text { Week }\end{array}$ & WSJ & $\begin{array}{c}\text { Financial } \\
\text { Times }\end{array}$ & U.S. News & Forbes \\
\hline Student Surveys & $\mathrm{x}$ & & & $\mathrm{x}$ & \\
\hline Recruiter Surveys & $\mathrm{x}$ & $\mathbf{x}$ & & $\mathrm{x}$ & \\
\hline Graduate Surveys & & & $\mathbf{x}$ & & \\
\hline Faculty Published Research & $\mathbf{x}$ & & $\mathbf{x}$ & & \\
\hline Faculty with Doctorate & & & $\mathrm{x}$ & & \\
\hline Employment Upon Graduation & & & $\mathbf{x}$ & $\mathbf{x}$ & \\
\hline Employment 3 Months After Graduation & & & $x$ & $x$ & \\
\hline Salary \& Bonus Upon Graduation & & & $\mathbf{x}$ & $\mathbf{x}$ & $\mathbf{x}$ \\
\hline ROI & & & $\mathrm{x}$ & & $\mathrm{x}$ \\
\hline Gender Diversity & & & $\mathrm{x}$ & & \\
\hline International Diversity & & & $\mathbf{x}$ & & \\
\hline Average undergrad GPA & & & & $\mathbf{x}$ & \\
\hline Average GMAT Score & & & & $\mathbf{x}$ & \\
\hline Average Acceptance Rate & & & & $\mathbf{x}$ & \\
\hline Out of State Tuition \& Fees & & & & $\mathrm{x}$ & \\
\hline Full-time Enrollment & & & & $x$ & \\
\hline Applicant Ranking of Credibility & $\# 1$ & $\# 2$ & \#3 & $\# 4$ & $\# 5$ \\
\hline
\end{tabular}

Figure 6 illustrates how these differences manifest themselves in the most recent Top Ten list of each publication. The average correlation between the five surveys is only 0.46.(Zimmerman, 2001) Since 1.00 shows complete correlation and 0.00 shows absolutely no correlation, this data indicates that there is relatively little correlation between the five publications and their rankings. 
First published at a time when the vast majority of MBA programs failed to keep buyer opinions in mind, the original idea behind the rankings was to force MBA providers to be responsive to their primary constituents: students and employers. The rankings therefore were intended to implement a system of reward and punishment to hold the universities accountable to their customers. (Mast, 2001) This system, has, in a sense, backfired. 
Figure 6. Publication's Top Ten MBA Rankings

\begin{tabular}{|c|c|c|c|}
\hline & \multicolumn{2}{|c|}{ Recent Rankings of Top Ten MBA Programs by } & Various Publications \\
\hline & Business Week 2006 & Financial Times 2007 & US NewS 2006 \\
\hline 1 & $\begin{array}{c}\text { University of Chicago } \\
\text { GSB }\end{array}$ & $\begin{array}{l}\text { Univ. of Pennsylvania } \\
\text { (Wharton) }\end{array}$ & $\begin{array}{c}\text { Harvard Business } \\
\text { School }\end{array}$ \\
\hline 2 & $\begin{array}{cl}\text { Univ. of Pennsylvania } \\
\text { (Wharton) }\end{array}$ & $\begin{array}{c}\text { Columbia Business } \\
\text { School }\end{array}$ & $\begin{array}{c}\text { Stanford University } \\
\text { GSB }\end{array}$ \\
\hline 3 & $\begin{array}{c}\text { Northwestern } \\
\text { University (Kellogg) }\end{array}$ & $\begin{array}{c}\text { Harvard Business } \\
\text { School }\end{array}$ & $\begin{aligned} \text { Univ. of Pennsylvania } \\
\text { (Wharton) }\end{aligned}$ \\
\hline 4 & $\begin{array}{c}\text { Harvard Business } \\
\text { School }\end{array}$ & $\begin{array}{c}\text { Stanford University } \\
\text { GSB }\end{array}$ & MIT (Sloan) \\
\hline 5 & $\begin{array}{l}\text { University of } \\
\text { Michigan (Ross) }\end{array}$ & $\begin{array}{c}\text { University of Chicago } \\
\text { GSB } \\
\end{array}$ & $\begin{array}{c}\text { Northwestern } \\
\text { University (Kellogg) }\end{array}$ \\
\hline 6 & $\begin{array}{c}\text { Stanford University } \\
\text { GSB }\end{array}$ & NYU (Stern) & $\begin{array}{c}\text { University of Chicago } \\
\text { GSB } \\
\end{array}$ \\
\hline 7 & MIT (Sloan) & Darthmouth (Tuck) & $\begin{array}{c}\text { Columbia Business } \\
\text { School }\end{array}$ \\
\hline 8 & UC Berkeley (Haas) & $\begin{array}{c}\text { Yale School of } \\
\text { Management }\end{array}$ & UC Berkeley (Haas) \\
\hline 9 & $\begin{array}{c}\text { Duke University } \\
\text { (Fuqua) }\end{array}$ & MIT (Sloan) & Darthmouth (Tuck) \\
\hline 10 & $\begin{array}{c}\text { Columbia Business } \\
\text { School }\end{array}$ & UCLA (Anderson) & UCLA (Anderson) \\
\hline & $\begin{array}{c}\text { The Wall Street } \\
\text { Journal } 2006\end{array}$ & Forbes 2005 & \\
\hline 1 & $\begin{array}{l}\text { University of } \\
\text { Michigan (Ross) }\end{array}$ & Dartmouth (Tuck) & \\
\hline 2 & Darthmouth (Tuck) & $\begin{array}{cc}\text { Univ. of Pennsylvania } \\
\text { (Wharton) }\end{array}$ & \\
\hline 3 & $\begin{aligned} \text { Carnegie } & \text { Mellon } \\
\text { University } & \text { (Tepper) }\end{aligned}$ & $\begin{array}{c}\text { University of Chicago } \\
\text { GSB }\end{array}$ & \\
\hline 4 & $\begin{array}{c}\text { Columbia Business } \\
\text { School }\end{array}$ & $\begin{array}{c}\text { Columbia Business } \\
\text { School }\end{array}$ & \\
\hline 5 & UC Berkeley (Haas) & $\begin{array}{l}\text { Yale School of } \\
\text { Management }\end{array}$ & \\
\hline 6 & $\begin{array}{c}\text { Northwestern } \\
\text { University (Kellogg) }\end{array}$ & $\begin{array}{c}\text { Stanford University } \\
\text { GSB }\end{array}$ & \\
\hline 7 & $\begin{array}{cl}\text { Univ. of Pennsylvania } \\
\text { (Wharton) }\end{array}$ & $\begin{array}{c}\text { Harvard Business } \\
\text { School }\end{array}$ & \\
\hline 8 & $\begin{array}{l}\text { UNC Chapel Hill } \\
\text { (Kenan-Flagler) }\end{array}$ & $\begin{array}{l}\text { University of } \\
\text { Virginia (Darden) }\end{array}$ & \\
\hline 9 & $\begin{array}{l}\text { Yale School of } \\
\text { Management }\end{array}$ & Cornell & \\
\hline 10 & MIT (Sloan) & $\begin{array}{c}\text { Northwestern } \\
\text { University (Kellogg) }\end{array}$ & \\
\hline
\end{tabular}


Some schools have simply become obsessed with their position on the rankings, to the point of even firing deans who fail to produce desired improvements in position.(Mast, 2001) More than just endangering the jobs of b-school deans, this quest to top the list of MBA programs has put business schools in a jam.

A number of observers have argued that these rankings lead some deans to focus on looking like a good school rather than being a good school.(Zimmerman, 2001) Why wouldn't they? After all, the typical tour of duty for a dean lasts between five and ten years, so deans have strong incentives to focus on tactics to enhance short-term rankings rather than utilize resources on things like research and doctoral education that only yield dividends long after the dean has left office. (Zimmerman, 2001) So, in trying to "look good," deans shift a large percentage of resources to engineer the ranking of their full-time MBA programs. Unfortunately, given the limited resources of most universities, this has robbed a large percentage of resources once devoted to undergraduate programs, curricular innovation and research. (Policano, 2005)

In his compelling paper entitled "Can American Business Schools Survive?" Jerold Zimmerman states:

This ratings race has caused schools to divert resources from investment in knowledge creation, including doctoral education and research, to short-term strategies aimed at improving rankings. The resulting decline in business doctorates is creating a severe shortage of quality faculty. American business schools are mortgaging their future; they are consuming their seed corn. (Zimmerman, 2001) 
Before 1985, the top U.S. business schools were research-centric. In fact, the quality of the business school's reputation was driven by the quality of its research.(Zimmerman, 2001) "Schools with cutting-edge research attracted the best students and top young faculty, as well as gifts and grants, which enable them to retain existing faculty." (Zimmerman, 2001) However, even though schools maintain a bias for research faculty, most MBA programs today face the reality that students and employers prefer teaching faculty over research faculty. (Zimmerman, 2001)

Consequently, one of the most common casualties of the resource reallocation that stems from the pursuit rankings is the business doctoral program. (Zimmerman, 2001) As resources are rerouted to furnish new facilities and advertising agendas, the doctoral programs are starved. These programs have shrunk because there is no funding to continue the student stipends that draw in high-quality students, and professors are stripped of their financial resources to conduct research that brings in the new knowledge.

More than financial resources are affected. Professors are also robbed of their time that is normally devoted to research because they are forced to maintain a larger teaching load.(Zimmerman, 2001) Schools are actually asking professors to teach extra classes instead of performing the much needed research.(Zimmerman, 2001) Research is where the primary instruction for the doctoral students occurs. The benefits for maintaining a doctoral program were already detailed in a preceding section of this chapter. Without such programs, business schools risk 
becoming stagnant in their ability to shape the leaders of tomorrow but, much worse, they lose their ability to educate the educators of tomorrow.

To further illustrate this point, John Kraft, Chair of the Association to Advance Collegiate Schools of Business (AACSB) and Dean of the University of Florida Business School, wrote that, "the top ten [business] Ph.D. producers have reduced by one-third the number of Ph.D.s produced annually compared to ten years ago ... In the next ten years the number of Ph.D. graduates will approach $50 \%$ of the output of the 1990s in the face of increasing demand for faculty." (Zimmerman, 2001) Deans might encourage research that has a high level of visibility via the news media, but this is mainly to enhance the school's standings in the rankings. (Zimmerman, 2001)

Rankings have dramatically changed business education in other significant and perhaps undesirable ways: (Policano, 2005)

- Higher GMAT requirements: Higher GMAT scores for entrants translate into higher rankings. Therefore schools have raised entrance requirements.

- Smaller cohorts: To compete against top tier school's brand recognition, second and third tier schools have adopted a strategy of decreased class sizes. This boosts the selectivity factor and possibly facilitates rankings increases, thereby attracting larger numbers of top students.

- Overemphasis on paychecks: This sends the message that the education, networking and quality of the program are not what is important. It implies that the salary after graduation is what is important. 
- Shifts in Spending: As schools divert money to improve rankings it weakens the quality of the learning environment. However more money for better faculty and better research facilities should also improve the learning environment. This presents a strategic dilemma of how business schools can balance between rankings and education in different ways to gain competitive advantage?

- More frills less substance: Business schools are adding student perks like fitness centers and extravagant décor, while neglecting classrooms and the learning environment.

- Marketing Bonanzas: AACSB conducted an informal survey that found 6 of 7 schools were undergoing major branding initiatives. Five had actually contracted with external PR agencies. These expenditures do not affect quality yet they likely increase rankings.

Tom McQuillan, executive director of the MBA program at Temple University's Fox School of Business commented on the focus on rankings:

It's an absolute top priority, because students take these rankings very seriously ... There's a tremendous amount of pressure to focus on the rankings, so it's very easy to get distracted from the things you should be doing. Institutions which have enjoyed a positive ranking and who slip four of five slots start looking at all their practices - and that program may have been very successful to begin with. (Wuorio, 2001)

So why pursue rankings at all? It has already been mentioned that the rankings system isn't a perfect science. Results are based on responses to a number of surveys, and not all of those given the surveys respond. The five publications that publish rankings do not agree on who 
should be in the top ten and in what order. They do not even agree on which criteria should be considered in the rankings.

Should it matter? Do students care what goes into determining the rankings? Most universities don't even think that students read the ranking methodology. (Tyson, 2001) Shouldn't students care how and why the school of their choices is ranked the way it is? It isn't like these rankings are movie reviews. One author made an analogy to demonstrate the danger of treating these rankings as such: "We only spend several dollars per ticket and a few hours at a movie; a business school student invests a great deal of money, time, and effort in business school and, to some extent, banks a career on choosing the right school." (Tyson, 2001)

Regardless of whether or not the students understand or even care to understand - the reasoning behind the rankings, the perception is that the higher ranked a school, the better it is. Case in point: The University of Pennsylvania's Wharton school was ranked number 1 by Business Week four times between 1993 and 2000. During those same years, the applicant pool increased dramatically, from 4,300 in 1993 to 8,400 in 1999. (Wuorio, 2001) In 2001, The Wall Street Journal ranked the Amos Tuck School of Business at Dartmouth number one. As a result, application inquiries increased sixty percent in the year between September 2000 and 2001. (Wuorio, 2001) In response to its ranking, Tuck's dean Paul Danos said, "It certainly has an effect on the number of students choosing to come here. But it also ratchets up everybody's expectations. Nobody wants to come to a place that's 
ranked 1 and leave when it's at number 20. And people who say they don't care about that are being just a bit disingenuous." (Wuorio, 2001)

It isn't just the spark to applications that drives the obsession with rankings. Success in rankings is also tied to increases in alumni funding. The Edwin L. Cox School of Business at Southern Methodist University was ranked 9 th by the Wall street Journal. This boosted alumni annual fund contributions by 150 percent in just a few years. Besides opening their pocketbooks, alumni also opened their schedules by increasing their involvement in the two mentoring programs the business school provides for its students. (Wuorio, 2001) This falls in line with the beliefs of one dean from a top-rated business school who stated, "The reality is that, independent of whether you believe rankings accurately reflect quality, the perception of the outside world is [that] it does and consequently resources flow to schools who are highly ranked." (Zimmerman, 2001)

The University of North Carolina's James Dean, Jr., recognizes that this obsession with always vying for higher rankings has created an "arms race" of sorts among the business schools. "The fact that once a school gets ranked highly, it can attract more students, resources, and faculty to remain near the top of the rankings only reinforces the idea that the rich get richer and the poor stay poor." (Wuorio, 2001)

The reason to drive for high rankings is the attempt to do one thing: develop a brand name. Branding is a very important aspect of competition in the MBA market. Sources say that establishing a brand name is one of the most 
urgent matters facing business school deans. The reasoning is tied back into rankings. According to Martin Schatz, "...the rankings have a tendency to become self-fulfilling prophecies." (Tyson, 2004) The higher a school is ranked, the better it is perceived to be. Therefore, the best potential students and faculty apply because they want to be a part of the best schools and, consequently, the school ends up producing the best graduates, partly because of the quality of the newly recruited faculty but mostly because of the high quality inputs (student applicants) in the first place. The higher the quality of graduates, the greater the school's reputation among recruiters. Finally, because the quality of students (measured by GMAT scores, undergraduate GPA, and school acceptance rate), the quality of the faculty (measured by research productivity and percentage with doctorates), and the perception of recruiters (measured via survey) all factor into one or more of the published rankings, the school's high ranking is reinforced or even improved. Figure 7 illustrates this self-reinforcing virtuous cycle for those schools fortunate enough to be ranking highly in the various publication. 


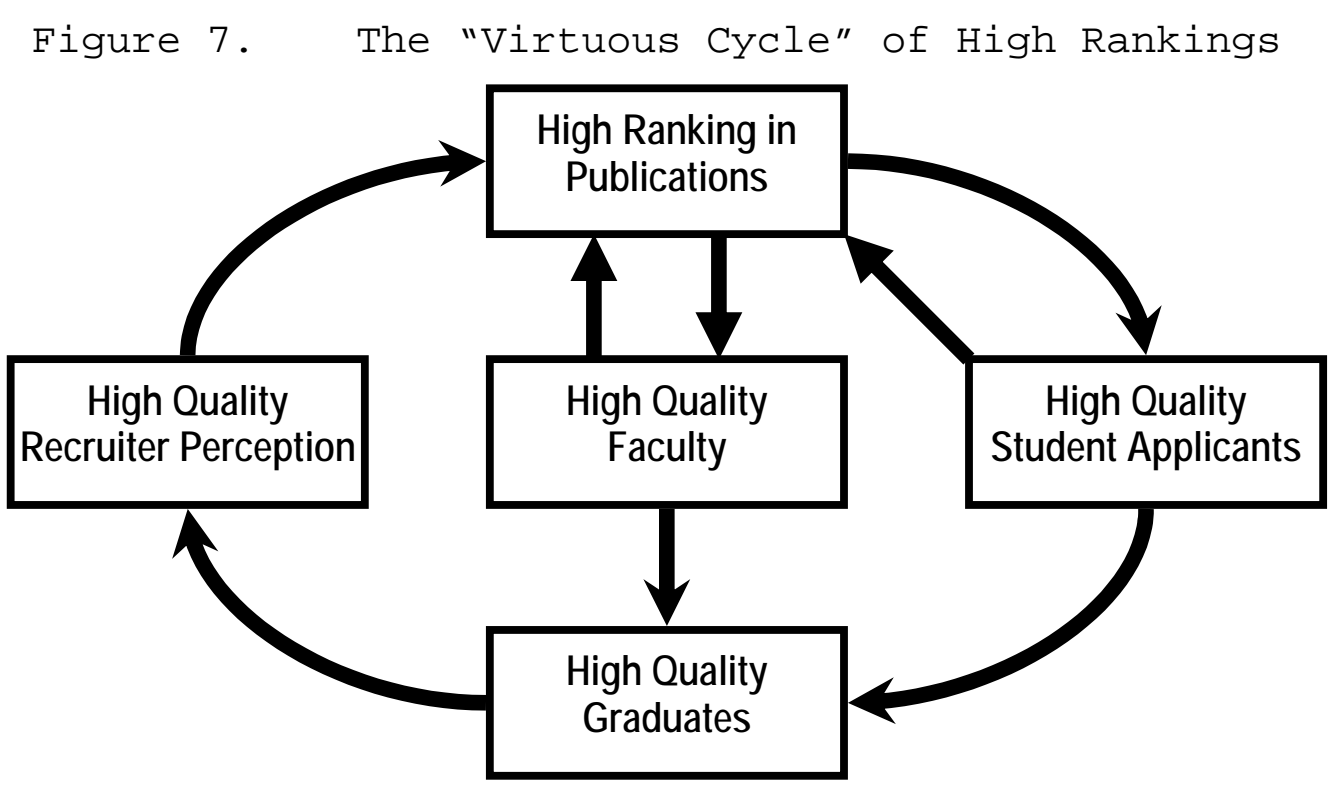

Suffice it to say, if a school is known by its name to be a high-quality school, it will in fact be (or become) a high quality school. Furthermore, note that the virtuous cycle in Figure 7 holds true even if all MBA programs provided the exact same real educational benefit (in particular, the cycle would remain even if the arrow connecting high quality faculty to high quality graduates was removed from Figure 7). In other words, the rankings may have very little to do with the actual quality of an MBA program and could instead be $100 \%$ the result of perception and, in particular, the rankings themselves.

Moreover, note that the same dynamics which create the virtuous cycle for highly ranked schools in Figure 7 also create a self-reinforcing "vicious cycle" for poorly ranked schools. This is illustrated in Figure 8, in which a low ranking leads to low quality student applicants and low quality faculty, which produces low quality graduates, which in turn produces a low quality perception among recruiters, which together reinforces or worsens the 
school's low ranking. Thus, it is also true that if a school is known by its name to be a low-quality school, it will in fact be (or become) a low quality school. When it comes to MBA rankings, therefore, the rich get richer and the poor get poorer.

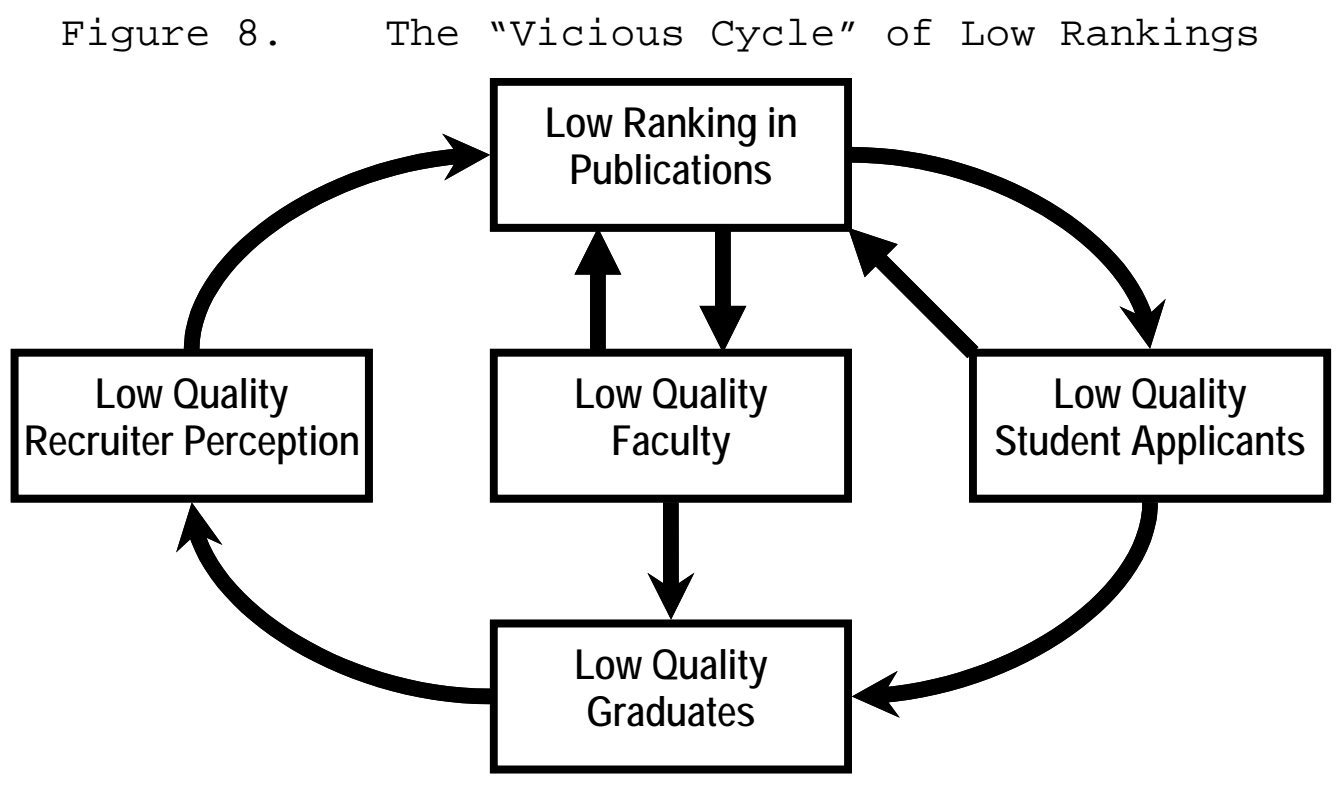

The resulting incredible importance of perception in general and rankings in particular make the branding of business schools a key element in their ability to attract higher quality professors, students, and donors. (Fairbank et al., 2005) Most schools are likely to undertake some sort of branding initiative as they seek to compete in this market. The largest push is likely to come from newly founded international business schools and U.S. schools that have a regional or local community frame of reference.(Fairbank et al., 2005) U.S. Regional schools hope to distinguish themselves from competitors at the 
local level, and thereby gain market share in a place typically dominated by smaller, local schools. (Fairbank et al., 2005)

Beyond seeking higher standings in the rankings, schools have begun to seek other methods to establish brand identity. Some AACSB-accredited schools in major markets are placing joint advertisements to distinguish themselves from non-accredited schools. (Fairbank et al., 2005) Due to the growing reputation of non-U.S. business schools and the increasing demand for business education worldwide, more students are choosing to acquire business education from non-U.S. providers. In addition, doctorally qualified faculties have a broader choice of highly regarded non-U.S. business schools than ever. (AACSB, 2002)

\section{Accreditation}

Accreditation is another means of setting MBA programs apart from others. There are 650 members in the AACSB. (Zimmerman, 2001) For AACSB accreditation requirements, see Appendix A. In the MBA industry, there are essentially three tiers of MBA programs. There are the ranked programs. Although the Top 20 are considered the elite, making the Top 50 is still an accomplishment. Below the ranked schools are the non-ranked accredited programs. These are the less revered schools that have met the accreditation standards but cannot compete on the same level as the ranked schools. Below the non-ranked programs, and at the bottom of the list, are the nonranked, non-accredited programs. These are the programs that do not conform to widely accepted standards of what a business school and an MBA program should be and consequently cannot compete for rankings. They are not 
necessarily bad programs. They could be brand new upstart programs that are in the process of gaining accreditation but have not yet done so.

\section{E. HORIZONTAL DIFFERENTIATION}

\section{Specialization}

Because of the virtuous and vicious cycles that serve to reinforce overall rankings of "quality" in this market, there is little opportunity for accredited but unranked (or lower ranked) business schools to compete head-on with "big boys" and actually substantively improve their reputation based on overall quality. Therefore, many MBA programs have looked for ways to compete via horizontal differentiation (i.e. specialization or focus) rather than vertical differentiation (i.e. overall quality to the mass market).

The MBA market in the U.S. is an unregulated industry that allows schools to develop their own distinctive styles and personalities, as well as to define their own missions. Understandably, a level of "cutthroat" competition exists in this market that is second to none. (Dobni \& Dobni, 1996) To succeed in such a competitive market, business schools have to capitalize on all available tools and technological resources to create their own competitive contexts or "niches" in which to compete. (Westerbeck, 2004) To create these unique competitive contexts, each school must look at the features it offers, from its faculty and programs to its schedule and delivery methods, and promote those that are most likely to draw attention. (Bisoux, 2006)

The market wasn't always like this. The MBA that was offered by North American business schools in the 1980s was largely undifferentiated. Due to the AACSB'S accreditation 
requirements to cover a "common body of knowledge," core and elective tracks rarely differed from campus to campus. (Schmotter, 2004) During the 1990s, however, the "onesize-fits-all" model was abolished due to immense pressure from stakeholders; the AACSB's accreditation standards were revised, giving individual programs the flexibility to carve out niches in which they could operate.

In some cases, a school might be particularly well known in certain elective areas, and this might drive students' decisions to take those specific courses. On the other hand, some schools decide to emphasize a specialized MBA that offers degrees in management with an emphasis in specific professional industries and disciplines, such as engineering or health care. By shifting the focus toward these interdisciplinary degrees, schools can exploit existing strengths, carve out a new niche, and create clusters of excellence within the institution.(Fairbank et al., 2005) The goal is to attract students with unique experience in certain professional areas by enabling them to earn an MBA specifically focused in that realm.

It is understandable that schools are quick to market the fact that they were highly ranked. Attaching a single number to a program has driven some to promote those elements that separate them from the others: outstanding faculty, ideal location, or outstanding parts of their curriculum. JoAnne Starr, MBA program assistant at the Graduate School of Management, University of California at Irvine, agrees, noting that the pressure on schools to clearly delineate their strengths has grown with the popularity of various published rankings. "You have to 
clarify what makes you distinctive. The question is, 'Do we know what our core value is that we can promote to students?'" (Wuorio, 2001)

Just because a school specializes in a particular field or curriculum doesn't mean that it can't benefit from published rankings. The rankings in the wall street Journal, for example, identify the top three programs in a number of specialty areas, and a number of lesser-known schools have been able to make a name for themselves by appearing in these specialty rankings. Babson College, for example, is ranked by the Wall street Journal as the second best business school in the field of entrepreneurship, Thunderbird is ranked number one in international business, Purdue University is ranked number three in operations management, and the University of Texas is ranked number three in accounting. None of those four schools, on the other hand, were even included on the wall street Journal's overall listing of top MBA programs, so it was only their specialization that enabled them to capture attention from the publication.

Smaller publications have begun creating even more specialized MBA rankings. Computerworld put out its fifth ranking of "techno MBA programs" in october 2001. (Wuorio, 2001) The rankings sought to determine which schools are putting out the best technology leaders. (Wuorio, 2001) In 1997, Working Woman ranked the most female friendly MBA programs. The report considered factors such as the school's percentage of students and faculty that were women, the diversity of views in its curriculum, and the opportunities for female students and alumnae to network.(Wuorio, 2001) other publications that ranked 
specialized MBA programs include success Magazine (ranking entrepreneurial schools) and Hispanic Business (ranking the top ten schools for Hispanics). (Wuorio, 2001)

\section{Partnership}

Another approach to differentiate programs is to form partnerships with proven business organizations and infuse their methodologies into the program curriculum. Columbia, which ranks No. 10, offers a new MBA called the Program for Social Intelligence. This program combines aspects of the proven management philosophies of such corporate giants as General Electric and Goldman Sachs, including brainstorming exercises and marketing plan simulations, and forms the program around them. (Lavelle \& Lehman, 2006) Another avenue of specialization is offering an MBA with an international focus. More than 400 international business programs are currently available in the U.S., up from less than 200 a decade ago. (AACSB, 2002)

\section{Regional Focus and Flexibility}

Not all schools have the means to completely revamp their curriculum. Instead, some instead simply shift the target customer of their programs.

Typically, small schools have had success attracting local students who do not want to travel too far from home. They offer convenience to working professionals who live nearby. To students who simply appreciate the advantages of a safe, comfortable environment where they can get close attention, small schools offer the solution. (Shinn, 2004a) This trend towards regional focus has led the wall street Journal to include a ranking of the top $5 \odot$ regional MBA programs in addition to its rankings of national and international programs. 
By being sensitive to students' rigorous and demanding work and family schedules, schools can reach a certain student population that needs creative program alternatives in terms of scheduling and content.(Bisoux, 2006) Some schools are shortening their programs to attract students who have neither the freedom nor the ability to devote 24 months to earning an MBA degree. This trend is catching on. In 2003, 37 percent of member programs took 21 to 22 months to complete; in 2005, that number dropped to 27 percent. Programs that take 17-18 months to complete, however, increased to 17 percent of members in 2005, up from 15 percent in 2003.(Bisoux, 2006) With intense competition for students and MBA providers desperately trying to maintain market share, on the other hand, there is a danger of designing programs that fall short of what an MBA program should be. MBA providers must therefore be careful about the degree to which they specialize or customize their MBA programs.

\section{F. ANALYSIS}

For better or worse, it is evident that competition for rankings currently drives the MBA industry. Universities expend vast resources in the pursuit of being highly ranked or even ranked at all. Rankings drive how students, faculty, and employers perceive the MBA program. In turn, how students, faculty, and employers perceive the MBA program drives rankings. However, rankings do not necessarily equate to the value of the education.

Just because one person went to the Harvard Business School and another went to a small, non-ranked school doesn't mean the education was less valuable. In fact, rankings may reveal very little about the actual quality of 
the education. All rankings reveal is what the average GPA and GMAT score is for its students, how many applicants the program turned away, average salary upon graduation for its graduates, how much research is published by the faculty, etc. Nowhere in the rankings is there a category for "quality of the education." The reason, many argue, is that an MBA has similar "real" intellectual value no matter where it comes from. MBA programs differ, without question. But in the end, many observers suggest that an MBA is an MBA.

Unfortunately for the students who attend a non-ranked school, there is a strong perception that a difference in the quality of the education exists. It is this perception that drives schools to compete as hard as they do for rankings in effort to establish themselves as "value leaders."

The Top 20 schools in any published ranking generally stay the Top 20, although the order may shift slightly from year-to-year. It is primarily the legacy of these schools that keeps them at the top. In recognition of this relative permanency in the rankings, some publications have even been accused of changing the weighting of their criteria slightly each year simply to create small changes in the rankings that could help sell more magazines.

The static and impenetrable nature of business school rankings therefore leaves little room for newcomers or small schools to make a big splash. Non-ranked programs thus do all kinds of things to set themselves apart from the rest of the pack, especially small programs that do not have access to the vast resources that the larger schools 
have. The reason is because, ultimately, whether they are ranked or not, they have to get students in the chairs.

As mentioned above, a few tactics exist to do this. Some have begun to revamp their curriculum, trying to offer more of what students want. Some have reduced "education" in favor of "training" to offer more of what employers want. This is because MBA programs are torn between meeting the desires of the students that want to gain knowledge that will help them throughout their management career and the employers that want MBA graduates to hit the ground running with basic applied business skills appropriate for an early-career position.

other schools have decided to specialize in a particular profession, creating a niche market inside the broader MBA market. As mentioned, Thunderbird is ranked first among MBA programs offering MBAs in international business and Babson College is ranked second in the field of entrepreneurship. Other schools specialize in medical MBAs or IT MBAs. Still others have decided to seek a regional strategy to create a brand. They seek to be the university for the local students that do not want to travel too far from home or are working professionals that have to work the MBA around their careers. Whatever the case, since breaking into the Top 20 (or even the top 50, in most cases) is virtually impossible, these programs have sought other avenues to set themselves apart.

The other aspect of the MBA industry that stands out is the fact that it is an expensive business. The rising salaries of professors and the rising costs of research are key contributors to the increasing costs. Tuition alone will not cover the costs of running an MBA program. The 
primary source of funding is donations and endowments from alumni. The schools that are the most successful are those that have been around a while and have long lines of alumni that are willing and able to give back to their alma maters. Even then, the big schools still utilize executive education, consulting services, and research projects to provide additional revenue. New programs or small ones do not have the lineages that may allow them to supplement their revenues in these ways and thus, consequently, they are even more at a disadvantage. These new and small MBA program also pursue additional avenues of funding but also must compete with other small schools for government funding that is diminishing year by year. Raising necessary funds is a problem that all MBA programs must deal with, and it will continue to compound.

To be a player in the MBA industry, a MBA program needs access to adequate revenue sources. Without it, it will be difficult to put together a program that carries any credibility. The next step is to earn accreditation. After that, it is necessary to decide if the program will compete for rankings in the overall MBA industry or if the program will seek out a niche strategy through specialization or a regional focus. Once that decision is made, it is simply a matter of hiring faculty and getting students to apply and come to the program. A program must maintain a long-term mindset. Being competitive in the MBA industry is not a sprint; it is a marathon. A program cannot be Harvard or Dartmouth in a year. It is about paying dues and making a name for the program with quality education and research. 


\section{BUYERS}

Depending on your perspective, the buyers of graduate management education are either the students, employers, or both. No matter the classification of these two different stakeholder groups, however, an effective industry analysis requires understanding the incentives and leverage of both groups.

\section{A. STUDENTS}

Students at MBA programs have waited an average of 62 months - or a little more than 5 years - between completing their undergraduate (first university) degree and enrolling in a graduate business program. Most MBA students did not even consider an MBA degree until about 3 years had passed since their undergraduate degree. (MBA.com, 2005b) Then, it typically takes about one and a half years before they'll actually apply to a graduate program after first considering graduate education. People applying to fulltime 2-year MBA programs submitted an average of 3.2 applications.(MBA.com, 2005b) After applications are submitted, about a month passes on average before an attempt to score highly on the Graduate Management Admission Test (GMAT) is made. Finally, six months after the GMAT is completed, a student typically enrolls in one of the graduate business programs that have accepted him/her. (MBA.com, 2005b)

\section{GMAT}

Before a student's first tuition payment is due, he/she must decide which program is right for them. This is important because simply applying to a program can cost between $\$ 100$ and $\$ 200$ per application. A Graduate 
Management Admission Test (GMAT) can cost upwards of $\$ 200$. (Tyson, spring 03) Costs are more than monetary. Students preparing for the GMAT spend an average of 97 hours preparing for the test. (MBA.com, 2005b)

According to a 2005 survey of 155 two-year business schools, the median average GMAT score among the schools was 592 (out of 800 ), with the $75^{\text {th }}$ percentile being 640, and the bottom $25^{\text {th }}$ percentile being 526. (AACSB, 2006b) Figure 9 shows how GMAT scores have changed over the last fifty-three years.

Figure 9. GMAT Data, Then vs. Now

\begin{tabular}{|l|l|l|}
\hline \multicolumn{1}{|c|}{ Category } & \multicolumn{1}{|c|}{$\mathbf{1 9 5 4}$} & \multicolumn{1}{|c|}{2002} \\
\hline GMAT volume at year-end & 2,553 & 249,632 \\
\hline $\begin{array}{l}\text { Number of U.S Programs requiring the } \\
\text { GMAT }\end{array}$ & 9 & 851 \\
\hline Price & $\begin{array}{l}\text { U.S. } \\
\$ 10\end{array}$ & $\begin{array}{l}\text { U.S. } \\
\$ 225\end{array}$ \\
\hline GMAT mean score & 500 & 528 \\
\hline
\end{tabular}

The GMAT examination is a standardized test designed to measure basic verbal, mathematical, and analytical writing skills that have been developed over a long period of time through education and work. (139, p 1) GMAT scores consistently outperform undergraduate GPA or any other quantitative measure as a predictor of academic success in MBA programs. (GMAC, 2006c) The best predictor of academic success, however, is achieved when GMAT factors are combined with undergraduate GPA. (GMAC, 2006c) The data show that the GMAT exam has exceptionally high "predictive 
validity" for most MBA programs. When one considers the range of variables that can have an effect on a student's First Year Average, such as motivation, job considerations, family considerations, course preferences, professor preferences, teaching quality, and grading quality, the predictive validity of these core admission data is quite impressive.

\section{Admissions}

In 2001, the majority (three-fourths) of MBA students had at least three years of pre-MBA work experience, (Edgington \& 0lkin, 2002) and experience continues to become an important aspect of admission criteria. (Conley, 2002) Many schools will take a chance on someone with minimal work experience, but schools also recognize that prior experience is associated with the ability to get a job after graduation, which is a big factor in determining rankings.(Conley, 2002) Regardless, the trend seems to be a drive toward recruiting younger and younger applicants. The intent is to pick up the stellar students before they get locked into a career from which they cannot take 2 years off when they become 27 or 28 . (Mast, 2002)

Overall, MBA admissions is considered an art. "It would be nice if admissions were a science," says Linda Meehan, once an assistant dean and executive director of admissions and financial aid at columbia Business school. "It would be nice to be able to rely on the GMAT score and not look at anything else. That would be easy, but it wouldn't give us what we are looking for, because what we are looking for is not measured in numbers only." (Fisher, 2002) While most schools look beyond GMAT scores, they also recognize the importance of the GMAT in assessing academic 
aptitude and the ability to handle a tough curriculum. (Mast, 2002) When you combine GMAT scores with GPA, course work, letters of recommendation, interviews, and essays, you can glean a pretty precise image of a student's abilities. (Tyson, 2002) Whatever the combination a school uses to determine admissions, the fact of the matter is that it is "an inherently and necessarily subjective process" that requires choosing between individuals who are equally qualified.(Tyson, 2002)

According to Jett Pihakis, once the director of domestic admissions for the Haas School of Business at the University of California, Berkeley, "It would be nice if there were one ideal applicant, however we'd have a class more homogenous than heterogeneous - and that is not what we want." (Mast, 2002)

Despite the stated desire for a heterogeneous student mix, most business schools do look for common traits, including academic prowess, initiative, leadership potential, ability to work in teams, and top-notch communication skills. (Mast, 2002) A former director of MBA admissions and financial aid at the wharton school of Business was quoted as saying, "I don't want a class full of investment bankers or consultants. I also want nontraditional students: people who have worked in government or the nonprofit world. The $\operatorname{mix}$ is what makes for an incredible learning environment." (Mast, 2002)

There are many reasons students choose to pursue an MBA, which is why self-assessment is so important. A prospective student needs to investigate the program and find the one that best fits their distinct personal attributes. (Mast, 2002) 
When individuals who were not enrolled in an MBA program but who had attended an MBA forum a year earlier were asked why they weren't currently attending an MBA program, the number one reason given was that the MBA program of their choice rejected them. The distant runnerup was that they were not satisfied with their GMAT. (Edgington \& Olkin, 2002) Nonetheless, the process of selfselection, or deciding to pursue an MBA and which programs to apply to, is probably a stronger determinant of the type of students that end up at a particular school than is the school's selection process. (Edgington \& 0lkin, 2002)

\section{Program Selection Criteria}

After deciding to pursue an MBA and taking the GMAT, students must narrow the choices of programs to which they will apply. Students are also becoming more and more brand conscious, but they aren't convinced simply by reputation that a school is high quality.

The following characteristics were listed as those that ranked highly when choosing the right program:

- Prestige and global recognition;

- Career options the school affords;

- Quality and reputation of the faculty;

- Rankings in publications; and

- Reputation of alumni. (Olkin, 2004)

See Figure 10 for a full ranking of criteria that students felt were important when choosing an MBA program.

The quality of the school's curriculum, satisfaction with an increase in long-term potential through the development of skills and abilities, and the quality of the faculty provide the greatest explanatory power in 
understanding how a student rates the overall value of the MBA degree.(GMAC, 2006b) To understand student satisfaction with the increase in long-term potential through the development of skills and abilities, one study conducted a survey and formed a regression analysis to determine which skills and abilities affect their satisfaction in relation to the others.(GMAC, 2006b) Improvements in the ability to think strategically are most likely to affect a student's satisfaction with long-term potential. (GMAC, 2006b)

Another survey asked prospective students to rank categories of key aspects in their school selection process. Figure 11 demonstrates the results of this survey .

Finally, for categories ranked one, two, or three in the previous survey, respondents received a question asking them to rate the importance of detailed criteria within the category. (Schoenfeld \& Bruce, 2005) Figure 12 demonstrates the results of this survey. Quality of the faculty emerges as the most important criterion used by perspective students in selecting a graduate business school, followed by the local respect and reputation of the school, and the program types offered.(Schoenfeld \& Bruce, 2005) Another study showed that one of the most powerful drivers of satisfaction with the school is the presence of a close-knit community. This aspect was important to all respondents, regardless of whether they were enrolled in a full-time, part-time, or executive MBA program. (GMAC, 2006b) 
Figure 10. School Selection Criteria

\begin{tabular}{|c|c|}
\hline \multicolumn{2}{|l|}{ School Selection Criteria } \\
\hline \multirow[b]{2}{*}{ Criteria } & Percent \\
\hline & $(n=5,253)$ \\
\hline Quality/reputation of the school & $75 \%$ \\
\hline Quality/reputation of the faculty & $66 \%$ \\
\hline Prestige or global recognition of the school & $64 \%$ \\
\hline It is an accreditation program & $62 \%$ \\
\hline The school's reputation in placing graduates in jobs & $60 \%$ \\
\hline Career options available to graduates & $58 \%$ \\
\hline Financial cost of school & $56 \%$ \\
\hline Availability of scholarships, grants or other financial aid & $55 \%$ \\
\hline Published rankings of its graduate management program & $52 \%$ \\
\hline Improved chances for an international career & $51 \%$ \\
\hline School offers the specific curriculum I wanted & $49 \%$ \\
\hline The students and faculty have diverse backgrounds and experience & $49 \%$ \\
\hline School offers a practice- oriented education & $44 \%$ \\
\hline Cost of living is affordable & $43 \%$ \\
\hline Reputation of alumni & $43 \%$ \\
\hline The school is close to employment opportunities & $38 \%$ \\
\hline Convenient class schedules & $37 \%$ \\
\hline The school is close to home or work & $29 \%$ \\
\hline $\begin{array}{l}\text { The school provides the opportunity to learn/improve a foreign } \\
\text { language }\end{array}$ & $26 \%$ \\
\hline There are people like me at this college or university & $25 \%$ \\
\hline The school is in an exciting city & $23 \%$ \\
\hline My employer will pay for my education at this school & $18 \%$ \\
\hline Personal experience as an undergraduate & $18 \%$ \\
\hline Other & $4 \%$ \\
\hline
\end{tabular}

Source: Global MBA Graduate Survey, 2006. 
Figure 11. Importance of School Selection Criteria

\begin{tabular}{|c|c|c|c|c|c|c|c|c|}
\hline & \multicolumn{6}{|c|}{ Program Type } & \multicolumn{2}{|c|}{ Total } \\
\hline & \multicolumn{2}{|c|}{ Full-Time } & \multicolumn{2}{|c|}{ Part-Time } & \multicolumn{2}{|c|}{ Executive } & \multirow[b]{2}{*}{ Mean } & \multirow[b]{2}{*}{ Rank } \\
\hline & Mean & Rank & Mean & Rank & Mean & Rank & & \\
\hline It was an accredited program & 4.1 & 1 & 4.3 & 1 & 4.4 & 1 & 4.2 & 1 \\
\hline Quality/reputation of the faculty & 4.0 & 4 & 3.9 & 5 & 4.1 & 3 & 4.0 & 2 \\
\hline $\begin{array}{l}\text { Prestige or global recognition of } \\
\text { the college or university }\end{array}$ & 4.0 & 3 & 3.8 & 6 & 4.0 & 6 & 4.0 & 3 \\
\hline $\begin{array}{l}\text { Location of the college or } \\
\text { university }\end{array}$ & 3.8 & 8 & 4.3 & 2 & 4.1 & 4 & 3.9 & 4 \\
\hline $\begin{array}{l}\text { Career options available to } \\
\text { graduates }\end{array}$ & 4.0 & 2 & 3.5 & 9 & 3.3 & 11 & 3.9 & 5 \\
\hline $\begin{array}{l}\text { Published rankings of its graduate } \\
\text { management program }\end{array}$ & 3.8 & 5 & 3.6 & 8 & 3.6 & 9 & 3.8 & 6 \\
\hline $\begin{array}{l}\text { School offered the specific } \\
\text { curriculum I wanted }\end{array}$ & 3.8 & 7 & 3.7 & 7 & 3.9 & 7 & 3.8 & 7 \\
\hline Local respect & 3.6 & 10 & 4.0 & 4 & 4.0 & 5 & 3.7 & 8 \\
\hline $\begin{array}{l}\text { The school's reputation in placing } \\
\text { graduates }\end{array}$ & 3.8 & 6 & 3.2 & 12 & 3.0 & 13 & 3.6 & 9 \\
\hline $\begin{array}{l}\text { The students and faculty had } \\
\text { diverse backgrounds and experience }\end{array}$ & 3.6 & 9 & 3.2 & 11 & 3.6 & 8 & 3.5 & 10 \\
\hline $\begin{array}{l}\text { Source: School Brand } \\
\text { Programs }\end{array}$ & Imag & & & and & Cho & ces & in & MBA \\
\hline
\end{tabular}

\section{Figure 12. Top Ten Standardized Ratings of Specific Criteria within Key Aspects}

\begin{tabular}{|l|c|c|}
\hline \multicolumn{1}{|c|}{ Specific Criterion } & Rank & $\begin{array}{c}\text { Standardized } \\
\text { Score }\end{array}$ \\
\hline Quality of the faculty & 1 & 4.24 \\
\hline Local respect/reputation & 2 & 4.12 \\
\hline Program type offered & 3 & 4.01 \\
\hline Rigor of academic program & 4 & 3.97 \\
\hline Quality of current students & 5 & 3.89 \\
\hline $\begin{array}{l}\text { Published ranking of its graduate management } \\
\text { program }\end{array}$ & 6 & 3.87 \\
\hline Successful alumni & 7 & 3.86 \\
\hline Job placement reputation of the school & 8 & 3.78 \\
\hline Program completion time & 10 & 3.75 \\
\hline Selectivity of admissions & 3.67 \\
\hline $\begin{array}{l}\text { *Te highest ranked category for each respondent is given a score of } 3, \text { the next } \\
\text { highest is given a score of 2, and the third highest is given a score of } 1 . \\
\text { specific piece of information is recorded where 6 equals extremely important and } 0 \\
\text { equals not at all important. Next, a computed score is derived by multiplying the } \\
\text { rank with the component scores for each respondent. Each of the computed scores is } \\
\text { the weighted by the overall percentage of respondents similarly ranking the overall } \\
\text { categories. Finally, the arithmetic mean is calculated fore each component. }\end{array}$ \\
\hline
\end{tabular}

Source: School Brand Images and Brand Choices in MBA Programs 


\section{Value of an MBA}

How do you judge the value of an MBA? One way is to look at Return-on-Investment (ROI). When you consider that an MBA is an investment into your future, using ROI to calculate the value of your investment makes perfect senses. On study did just that.

To determine the ROI numbers for a potential MBA graduate, total estimated costs were obtained by adding together the published data for each school's tuition and fees plus the pre-MBA salaries given up (multiplied by two plus an added U.S. average salary increase for the second year number). Post-MBA salaries were obtained through survey data supplied by surveys taken from MBA Alumni groups. The 10-year gain from an MBA was then calculated before taxes and adjusted for the time value of money.(Holtom \& Inderrieden, 2006) See Figure 13 for the overall numbers.

Figure 13. Overall Numbers

\begin{tabular}{|l|c|}
\hline \multicolumn{2}{|c|}{ Overall Numbers } \\
\hline Pre-MBA Salary & $\$ 51,857$ \\
\hline Post-MBA Salary & $\$ 78,745$ \\
\hline Total Cost & $\$ 121,641$ \\
\hline Net Increase in Salary & $\$ 26,888$ \\
\hline Percent Increase in Salary & $52 \%$ \\
\hline 10-Year Gain from MBA & $\$ 337,105$ \\
\hline Return on Investments (R0I) & $177 \%$ \\
\hline Annualized ROI & $18 \%$ \\
\hline Payback Period (years) & 4.5 \\
\hline
\end{tabular}

Figure 14 shows how top ten schools compare to non-top ten schools in these categories. Graduates from schools outside the Top 10 experienced increases in salary that were nearly equal to the Top 10 (54 percent vs. 56 percent, respectively). Moreover, given that the costs of the Top 
10 programs were higher (both in tuition and opportunity cost of foregone salary), the ROI was lower and the payback period for graduates of the Top 10 programs was longer by 15 months on average.

Figure 14. Impact of Top 10 Ranking

\begin{tabular}{|l|c|c|}
\hline \multicolumn{1}{|c|}{ Variable } & Top 10 & Not Top 10 \\
\hline Pre-MBA Salary & $\$ 61,935$ & $\$ 51,619$ \\
\hline Post-MBA Salary & $\$ 96,420$ & $\$ 79,703$ \\
\hline Total Cost & $\$ 198,321$ & $\$ 123,712$ \\
\hline Net Increase in Salary & $\$ 34,485$ & $\$ 28,084$ \\
\hline Percent Increase in Salary & $56 \%$ & $54 \%$ \\
\hline 10-Year Gain from MBA & $\$ 432,348$ & $\$ 352,103$ \\
\hline Return on Investments (R0I) & $118 \%$ & $185 \%$ \\
\hline Annualized R0I & $12 \%$ & $18 \%$ \\
\hline Payback Period (years) & 5.8 & 4.4 \\
\hline
\end{tabular}

For specific schools, the payback period can be as long as 14 years.(Holtom \& Inderrieden, 2006; Holtom \& Inderrieden, 2006) To provide a broader comparison, the study also examined the outcomes achieved by graduates from the Top 50 schools vs. those outside the Top 50. Figure 15 provides the results of this comparison.

Figure 15. Impact of Top 50 Ranking

\begin{tabular}{|l|c|c|}
\hline \multicolumn{1}{|c|}{ Variable } & Top 50 & Not Top 50 \\
\hline Pre-MBA Salary & $\$ 53,019$ & $\$ 50,680$ \\
\hline Post-MBA Salary & $\$ 83,736$ & $\$ 73,448$ \\
\hline Total Cost & $\$ 141,717$ & $\$ 95,777$ \\
\hline Net Increase in Salary & $\$ 30,718$ & $\$ 22,768$ \\
\hline Percent Increase in Salary & $58 \%$ & $45 \%$ \\
\hline 10-Year Gain from MBA & $\$ 385,116$ & $\$ 285,452$ \\
\hline Return on Investments (R0I) & $172 \%$ & $198 \%$ \\
\hline Annualized R0I & $17 \%$ & $20 \%$ \\
\hline Payback Period (years) & 4.6 & 4.2 \\
\hline
\end{tabular}


Oddly enough, the ROI is higher and the payback period is shorter for graduates of programs outside the Top 50. These results indicate that students at lower tier MBA programs actually enjoy a higher return on their investment than students at higher tier schools. Note, however, that it is important to consider selection effects when interpreting these results: the students at lower tier schools differ from students at higher schools, most importantly in terms of their foregone pre-MBA salary. Therefore the results of this analysis can not be interpreted to suggest that a lower tier school is a better investment for all students.

A different study estimated the total ROI as of 2006 that had been achieved by the MBA classes of 2000 to 2005 . The mean percentage of investment that MBA graduates had recouped was 45\%, 54\%, 60\%, 67\%, 71\%, and 77\%, from 2000 to 2005 respectively.(GMAC, 2006c) Another survey asked graduates if pursuing an MBA degree was the right decision, most respondents said they definitely made the correct decision. (GMAC, 2006c)

According to the Council of Graduate Schools, the number of master's degrees granted in the U.S. has increased 61 percent since 1984. Business degrees are second only to education as far as master's degrees being awarded and are quickly on the rise. The number of MBAs given in 2000 was 46 percent greater than that number given in 1990. (Fisher, 2002)

Because demand for the MBA degree is driven by many factors including the real as well as perceived value, we end this section by examining graduates' perceptions of the value of the degree. Specifically, they were asked: When 
you compare the total monetary cost of your MBA program to the career opportunities you have received as a result of obtaining your degree, how would you rate the overall value of your MBA degree? The results are presented in Figure 16.

Figure 16. Value of the MBA Program

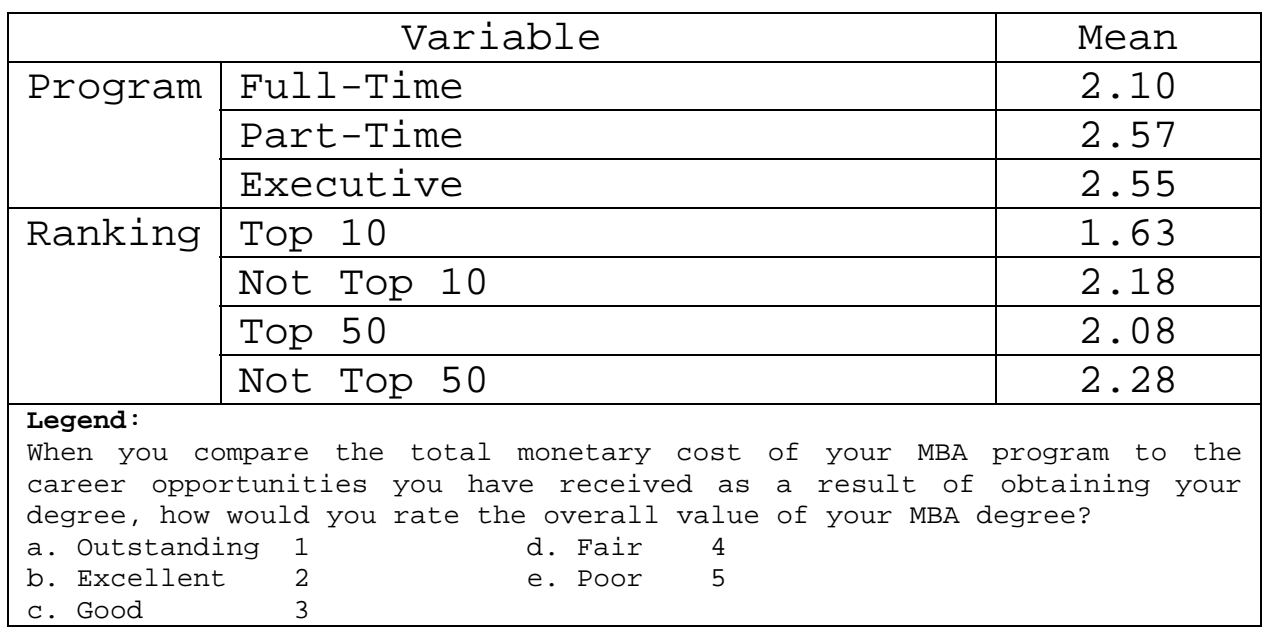

Source: Examining the Value Added by Graduate Management Education, 2006

Graduates of full-time programs were the most upbeat, followed by executive MBAs and part-timers. It is also interesting to note that, despite the earlier analysis indicating that students at lower tier MBA program enjoy a higher return on their investment, graduates from top 10 schools rated the overall value of their MBA degree significantly higher than did graduates from schools outside the top 10.(Holtom \& Inderrieden, 2006)

Finally, to help us understand what it is about the MBA that generates such high satisfaction among graduates, Figure 17 shows graduate ratings of satisfaction with specific aspects of the MBA degree. 
Figure 17. Satisfaction with Aspects of the MBA Degree

\begin{tabular}{|l|c|}
\hline \multicolumn{1}{|c|}{ Aspect } & $\begin{array}{c}\text { Satisfaction } \\
\text { Rating }\end{array}$ \\
\hline Job Security & 2.64 \\
\hline Increase in work environment flexibility & 2.04 \\
\hline $\begin{array}{l}\text { Preparation to get a good job in the } \\
\text { business world }\end{array}$ & 2.00 \\
\hline $\begin{array}{l}\text { Opportunity to network and to form } \\
\text { relationships with long-term value }\end{array}$ & 1.96 \\
\hline An increase in earning power & 1.90 \\
\hline Opportunity for quicker advancement & 1.86 \\
\hline $\begin{array}{l}\text { Development of your management } \\
\text { knowledge/technical skills }\end{array}$ & 1.74 \\
\hline Credentials you desired & 1.74 \\
\hline An increase in your career options & 1.70 \\
\hline $\begin{array}{l}\text { Opportunity to improve } \\
\text { personally yourself }\end{array}$ & 1.59 \\
\hline $\begin{array}{l}\text { Legend: Extremely satisfied }=1 ; \text { very satisfied }=2 ; \text { somewhat satisfied } \\
\text { Not very satisfied }=4 ;\end{array}$, Not at all satisfied $=5$
\end{tabular}

Source: Examining the Value Added by Graduate Management Education, 2006

\section{Salaries}

Another common way to look at the value of an MBA is too look at the salary received following the attainment of the degree. Corporate recruiters surveyed by GMAC from 2002-2006 were asked to estimate the starting annual salary for their new professional hires from MBA schools relative to other graduate programs. On average, starting annual salaries for MBA graduates was $\$ 11,000$ more than other graduates. (Murray, 2006) on the other hand, another study demonstrated that employees who have been in the workforce longer earn significantly more per year than those who recently graduated with an MBA.

According to one study the mean 2006 annual salary for MBAs who had graduated in years 2000 to 2005 , was $\$ 107,694$, $\$ 101,319, \quad \$ 90,263, \quad \$ 87,874, \$ 82,578, \quad$ and $\$ 82,466$ respectively. (GMAC, 2006b) This shows that the longer an 
MBA is in the work force, the higher their salary is. In five years, an MBA can expect an increase of approximately 130 percent in salary. The same trend can be seen in the average total compensation package. The mean total compensation package in 2006 for MBA graduates who had graduated in the years 2000 to 2005 was \$157,821, \$134,759, $\$ 113,347, \$ 113,208, \$ 109,161$, and $\$ 104,888$, respectively. (GMAC, 2006c)

The economic benefit enjoyed by a graduate business degree recipient was $\$ 659,726$ as compared to that of the average graduate degree recipient with a value of \$254,085. (Committee on Issues in Management Education, 2005) Benefits of an MBA include: higher starting salary, greater compensation growth, more stable long-term employment, and a higher likelihood of participating in the workforce. In 2001, the lifetime earning power of the "average" MBA was about $\$ 550,000$ greater than the average college graduate. From 1992-2002, in the U.S., the average compensation for each MBA grew from $\$ 56,000$ after completing their degrees to $\$ 387,600$ (including bonuses and other compensation) after ten years. This is compared to the $\$ 43,000$ average salary for those with a non-management college degree. (Committee on Issues in Management Education, 2005)

Figure 18 shows a graph of average annual base salary among MBA graduates who have received or accepted an offer of employment, while Figure 19 presents a comparison of starting annual salaries for MBA and non-MBA graduates from 2002-2006. 
Figure 18. Average Base Salary among MBA Grads who Received/Accepted Offer of Employment

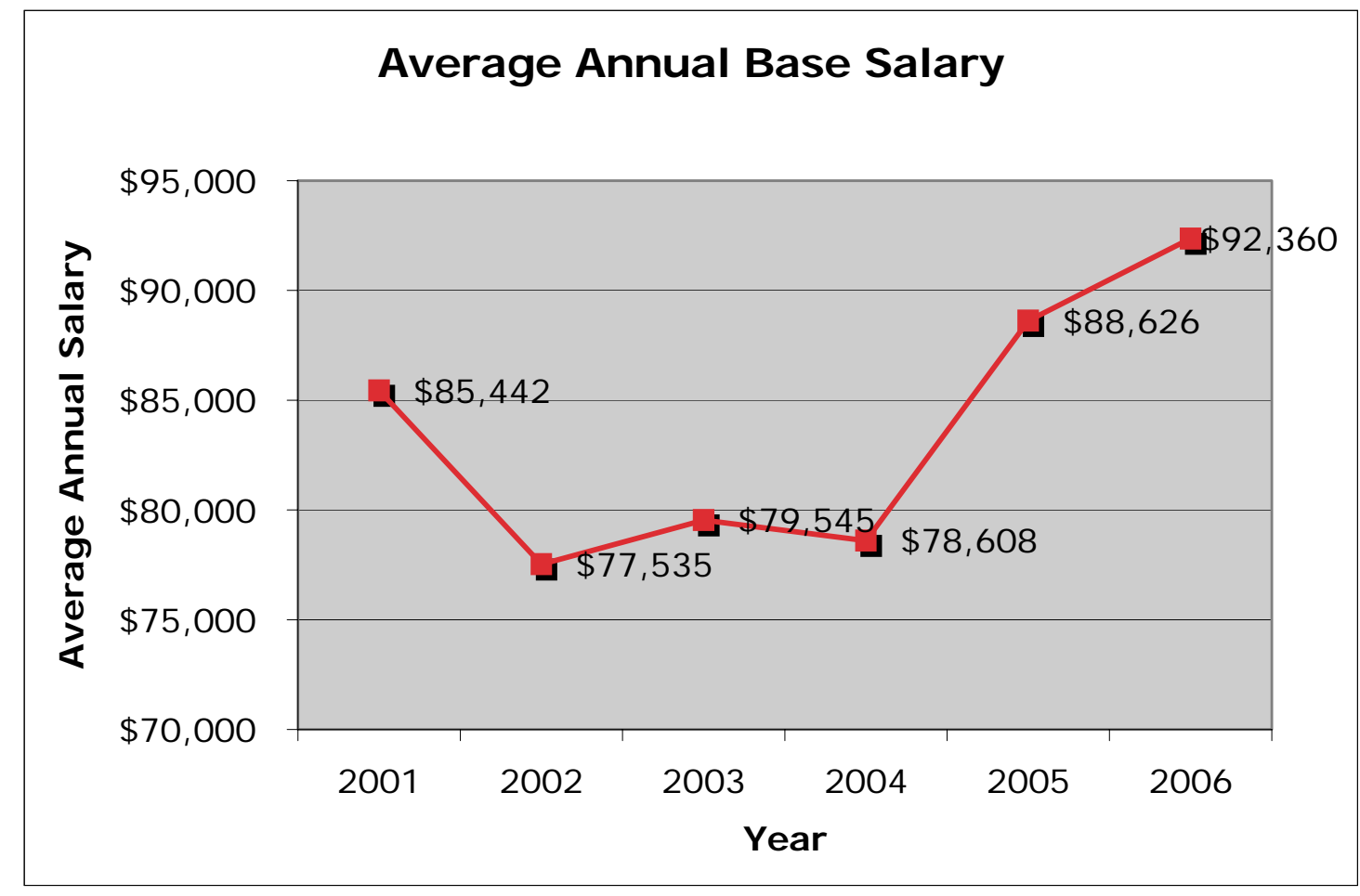

MBA.com Registrants Survey Comprehensive Data Report, 2005

Figure 19. Estimated Starting Salary for New Hires

\begin{tabular}{|l|c|c|c|c|c|}
\hline \multicolumn{7}{|c|}{ Year-to-Year Comparison } \\
\cline { 2 - 6 } & \multicolumn{5}{|c|}{ U.S. Dollars (Mean) } \\
\cline { 2 - 7 } New Hire & 2002 & 2003 & 2004 & 2005 & 2006 \\
\hline From MBA Program & $\$ 72,021$ & $\$ 73,859$ & $\$ 77,066$ & $\$ 78,040$ & $\$ 80,809$ \\
\hline $\begin{array}{l}\text { From other } \\
\text { graduate program }\end{array}$ & $\$ 52,322$ & $\$ 56,518$ & $\$ 62,371$ & $\$ 60,865$ & $\$ 65,780$ \\
\hline $\begin{array}{l}\text { From undergraduate } \\
\text { program }\end{array}$ & $\$ 41,381$ & $\$ 42,936$ & $\$ 45,029$ & $\$ 45,652$ & $\$ 46,436$ \\
\hline
\end{tabular}

Source: MBA Alumni Perspectives Survey, April 2006

The total additional compensation package for new MBA hires has an additional value of $\$ 18,928$. (GMAC, 2006a)

Students who responded to yet another survey reported that they made, on average, an annual salary of $\$ 61,302$ before entering the MBA program. They expect to earn an 
average annual salary of $\$ 86,350$ upon graduation. This represents a 41 percent increase.(GMAC, 2006b) Also asked was if the graduating students were receiving a signing bonus. Almost half (47\%) expect to receive some form of signing bonus of somewhere around $\$ 15,457$. Figure 20 shows salary and bonus statistics for MBA graduates with various levels of work experience prior to entering the MBA program. (GMAC, 2006b)

Figure 20. Salaries and Bonuses for Respondents who Accepted a Job Offer, by Work Experience

\begin{tabular}{|l|c|c|c|}
\hline $\begin{array}{l}\text { Annual Base Salary } \\
\text { and Signing Bonus }\end{array}$ & $\begin{array}{c}\text { Less than } \\
\mathbf{3} \text { years }\end{array}$ & $\begin{array}{c}\mathbf{3} \text { years, but } \\
\text { less than } \mathbf{6} \\
\text { years }\end{array}$ & $\begin{array}{c}\mathbf{6} \text { or more } \\
\text { years }\end{array}$ \\
\hline $\begin{array}{l}\text { Annual base salary } \\
\text { earned before } \\
\text { starting MBA }\end{array}$ & $\mathbf{\$ 4 0 , 3 4 9}$ & $\mathbf{\$ 5 1 , 7 1 8}$ & $\mathbf{\$ 7 5 , 5 2 9}$ \\
\hline $\begin{array}{l}\text { Annual base salary } \\
\text { expected in first } \\
\text { job after } \\
\text { graduation }\end{array}$ & $\mathbf{\$ 6 8 , 3 9 9}$ & $\$ 81,710$ & $\$ 100,887$ \\
\hline $\begin{array}{l}\text { Pre- and post-MBA } \\
\text { difference (\$) }\end{array}$ & $\$ 28,050$ & $\$ 29,992$ & $\$ 25,358$ \\
\hline $\begin{array}{l}\text { Pre- and post-MBA } \\
\text { difference (\%) }\end{array}$ & $70 \%$ & $58 \%$ & $34 \%$ \\
\hline $\begin{array}{l}\text { Percentage expect } \\
\text { to receive signing } \\
\text { bonus }\end{array}$ & $44 \%$ & $55 \%$ & $43 \%$ \\
\hline $\begin{array}{l}\text { Amount of signing } \\
\text { bonus }\end{array}$ & $\mathbf{\$ 1 0 , 7 3 6}$ & $\$ 16,256$ & $\$ 17,521$ \\
\hline${ }^{*}$ p..05; Items in bold in the contingency table significantly affect \\
the overall $x^{2}$ statistic.
\end{tabular}

Source: Global MBA Graduate Survey, 2006

Another consideration for MBA students is how to pay for the education. Figure 21 shows just how prospective students plan on funding their MBA. The results reveal 
that the majority of students plan on getting loans to cover the costs of graduate education. (MBA.com, 2005a)

Figure 21. Method of Financing Graduate Management Education

\begin{tabular}{|l|c|}
\hline \multicolumn{2}{|c|}{$\begin{array}{c}\text { Method of Financing Graduate Management Education } \\
\text { (Average Percent of Education Financed by Each Student) }\end{array}$} \\
\multicolumn{1}{|c|}{ Financial Source } & $\begin{array}{c}\text { Enrolled/ } \\
\text { Admitted }\end{array}$ \\
\cline { 2 - 2 } & $\mathrm{n}=1,188$ \\
\hline \hline Loans & $\mathbf{2 7 \%}$ \\
\hline Employer reimbursement/sponsorships* & $\mathbf{1 7 \%}$ \\
\hline Grants, fellowships, scholarships* & $\mathbf{1 5 \%}$ \\
\hline Personal Earnings* & $\mathbf{1 3 \%}$ \\
\hline Support from parents* & $\mathbf{1 3 \%}$ \\
\hline Personal Savings & $11 \%$ \\
\hline Spouse's (partner's) earnings & $\mathbf{2 \%}$ \\
\hline Other & $\mathbf{2 \%}$ \\
\hline \hline Total & $100 \%$ \\
\hline $\begin{array}{l}* p \leq 0.05 ; \text { Items in bold represent significant differences based on Bonferroni } \\
\text { comparison in an ANOVA. }\end{array}$ \\
\hline
\end{tabular}

Source: Global MBA Graduate Survey, 2006

When asked whether or not earning the MBA degree was worth the price and if they would do it all over again, knowing what they know now, a remarkable 72 percent said "definitely yes." The rest of those survey results can be seen in Figure 22. (MBA.com, 2005a)

Figure 22. Right Decision to Pursue the MBA Degree

\begin{tabular}{|l|c|}
\hline $\begin{array}{c}\text { Knowing what you know now, } \\
\text { would you still have } \\
\text { pursued an MBA Degree? }\end{array}$ & $\begin{array}{c}\text { Full-Time } \\
(n=2,828)\end{array}$ \\
\hline Definitely yes & $72 \%$ \\
\hline Probably yes & $22 \%$ \\
\hline Probably no & $4 \%$ \\
\hline Definitely no & $1 \%$ \\
\hline Total & $100 \%$ \\
\hline Source: MBA.com Registrants Survey, 2005
\end{tabular}


Figure 23 shows the results of a survey of 3,415 individuals considering an MBA concerning their motivation for choosing to pursue management education. The number one motivator was the hope that the MBA would provide an opportunity for more challenging/interesting work in the future.

Figure 23. Motivation to Pursue a Graduate Management Education

\begin{tabular}{|c|c|}
\hline \multicolumn{2}{|l|}{$\begin{array}{l}\text { Motivation to Pursue a Graduate Management Education } \\
\text { (Percent Very True to Me) }\end{array}$} \\
\hline \multirow[t]{2}{*}{$\begin{array}{l}\text { My Reason for pursuing graduate management education is } \\
\text { because it will... }\end{array}$} & $\begin{array}{c}\text { Among Those } \\
\text { Applying/Plan } \\
\text { to Apply }\end{array}$ \\
\hline & $(n=3,415)$ \\
\hline $\begin{array}{l}\text { Provide me an opportunity for more challenging/interesting work in } \\
\text { the future* }\end{array}$ & $67 \%$ \\
\hline give me a sense of personal satisfaction and achievement* & $61 \%$ \\
\hline be a part of my planned career development* & $59 \%$ \\
\hline improve my long term income and financial stability* & $57 \%$ \\
\hline allow me to remain marketable (competitive)* & $57 \%$ \\
\hline $\begin{array}{l}\text { allow me to obtain the professional credentials I need for } \\
\text { advancement* }\end{array}$ & $56 \%$ \\
\hline provide me the right connections to get a good job in the future* & $46 \%$ \\
\hline help me develop the skills necessary to do my job* & $46 \%$ \\
\hline allow me to transition from my current career path to a new one* & $41 \%$ \\
\hline help me to develop the confidence I need to succeed* & $40 \%$ \\
\hline help me achieve my goal of starting my own business* & $34 \%$ \\
\hline allow me to change occupational area* & $31 \%$ \\
\hline help me get the respect I deserve at work* & $26 \%$ \\
\hline
\end{tabular}

Source: Global MBA Graduate Survey, 2006

Figure 24 shows the results of a survey of the same 3,415 potential MBA students asking about their reservations, if any, about pursuing an MBA degree. The number one concern was related to affordability. 
Figure 24. Reservations about Pursuing Graduate Management Education

\begin{tabular}{|c|c|}
\hline \multicolumn{2}{|c|}{$\begin{array}{l}\text { Reservations about Pursuing a Graduate Management Education } \\
\text { (Percent Very True to Me) }\end{array}$} \\
\hline \multirow[b]{2}{*}{ Reservations } & $\begin{array}{c}\text { Among Those } \\
\text { Applying/Plan } \\
\text { to Apply }\end{array}$ \\
\hline & $(n=3,415)$ \\
\hline The interviews I may have to have may be a barrier for me & $4 \%$ \\
\hline The essays I have to write bay be a barrier for me & $5 \%$ \\
\hline The recommendations I need to get may be a barrier for me* & $5 \%$ \\
\hline My scores on admission tests may be a barrier for me* & $12 \%$ \\
\hline My employment history may be a barrier for me & $6 \%$ \\
\hline My undergraduate academic record may be a barrier for me* & $9 \%$ \\
\hline It is too intimidating & $3 \%$ \\
\hline It may require me to delay accepting attractive job opportunities & $6 \%$ \\
\hline I may not receive the same benefits others will & $5 \%$ \\
\hline It may require me to take on large financial debts* & $29 \%$ \\
\hline The economy/job prospects are too uncertain & $5 \%$ \\
\hline It may require more money that I have available* & $33 \%$ \\
\hline $\begin{array}{l}\text { It would severely limit the time I have for people who are } \\
\text { important to me* }\end{array}$ & $8 \%$ \\
\hline $\begin{array}{l}\text { It may require me to postpone marriage, having a child, or other } \\
\text { personal plans }\end{array}$ & $10 \%$ \\
\hline $\begin{array}{l}\text { The demands of graduate business school on my time/energy } \\
\text { may be too great }\end{array}$ & $8 \%$ \\
\hline
\end{tabular}

Source: Global MBA Graduate Survey, 2006

In another survey, respondents were asked to rate the overall value of their MBA degree by comparing the total cost of the degree to the career opportunities received because of the degree. Sixty-three percent of the graduates stated that the value of their MBA degree was outstanding or excellent relative to cost. (MBA.com, 2005a)

Their responses can be seen in Figure 25. (MBA.com, 2005a) 
Figure 25. Overall Value of the MBA Degree

\begin{tabular}{|l|c|c|}
\hline \multicolumn{1}{|c|}{ Response } & $\begin{array}{c}2005 \text { Percentage } \\
(n=2,828)\end{array}$ & $\begin{array}{c}2006 \text { Percentage } \\
(n=6,139)\end{array}$ \\
\hline Outstanding & $24 \%$ & $22 \%$ \\
\hline Excellent & $34 \%$ & $41 \%$ \\
\hline Good & $27 \%$ & $29 \%$ \\
\hline Fair & $10 \%$ & $7 \%$ \\
\hline Poor & $5 \%$ & $1 \%$ \\
\hline Total & $100 \%$ & $100 \%$ \\
\hline
\end{tabular}

Source: MBA.com Registrants Survey, 2005

The same survey also asked students to rate the various aspects of their degree that they felt added the most value. The top three aspects that received a rating of outstanding or excellent were faculty (68\%), fellow students (64\%), and the curriculum (57\%). (Global MBA graduate survey2006)

When asked to describe the school's culture, most students used the following attributes to do so: collaborative; heterogeneous student body; active learning; academic curriculum; personal; small class sizes; teachingoriented; team emphasis; egalitarian; emphasizes critical discussion; casual; and close-knit community. (MBA.com, 2005a)

Figure 26 shows how students rated their satisfaction of their MBA for each of several different benefits. Graduating students were also asked to rate their level of improvement for various skills and abilities. (MBA.com, 2005a) See Figure 27 for results. 
Figure 26. Satisfaction with the MBA Degree

\begin{tabular}{|c|c|c|c|c|c|c|}
\hline \multirow[b]{2}{*}{$\begin{array}{c}\text { My MBA degree has given } \\
\text { me... }\end{array}$} & \multicolumn{6}{|c|}{$(n=6,139)$} \\
\hline & $\begin{array}{l}\text { Extremely } \\
\text { Satisfied }\end{array}$ & $\begin{array}{l}\text { Very } \\
\text { Satisfied }\end{array}$ & $\begin{array}{l}\text { Somewhat } \\
\text { Satisfied }\end{array}$ & $\begin{array}{l}\text { Not Very } \\
\text { Satisfied }\end{array}$ & $\begin{array}{l}\text { Not } \\
\text { at } \\
\text { all } \\
\text { Sati- } \\
\text { sfied }\end{array}$ & Total \\
\hline $\begin{array}{l}\text { A sense of personal } \\
\text { satisfaction }\end{array}$ & $50 \%$ & $37 \%$ & $10 \%$ & $2 \%$ & $1 \%$ & $100 \%$ \\
\hline $\begin{array}{l}\text { Credentials I need to } \\
\text { increase career options }\end{array}$ & $38 \%$ & $46 \%$ & $14 \%$ & $2 \%$ & $\odot \%$ & $100 \%$ \\
\hline $\begin{array}{l}\text { An opportunity for more } \\
\text { challenging/interesting } \\
\text { work in the future }\end{array}$ & $38 \%$ & $45 \%$ & $15 \%$ & $2 \%$ & $1 \%$ & $10 \odot \%$ \\
\hline $\begin{array}{l}\text { An increase in long-term } \\
\text { potential through the } \\
\text { development of skills/ } \\
\text { abilities }\end{array}$ & $37 \%$ & $48 \%$ & $13 \%$ & $2 \%$ & $1 \%$ & $100 \%$ \\
\hline $\begin{array}{l}\text { The ability to remain } \\
\text { marketable (competitive) }\end{array}$ & $37 \%$ & $47 \%$ & $13 \%$ & $2 \%$ & $\odot \%$ & $100 \%$ \\
\hline Advancement potential & $36 \%$ & $47 \%$ & $15 \%$ & $2 \%$ & ๑\% & $100 \%$ \\
\hline $\begin{array}{l}\text { The potential for long } \\
\text { term income and } \\
\text { financial stability }\end{array}$ & $33 \%$ & $45 \%$ & $19 \%$ & $3 \%$ & $\odot \%$ & $10 \odot \%$ \\
\hline $\begin{array}{l}\text { Confidence I need to } \\
\text { succeed }\end{array}$ & $32 \%$ & $45 \%$ & $19 \%$ & $3 \%$ & $1 \%$ & $100 \%$ \\
\hline Respect and recognition & $27 \%$ & $46 \%$ & $23 \%$ & $3 \%$ & $1 \%$ & $100 \%$ \\
\hline $\begin{array}{l}\text { The ability to change } \\
\text { occupational area }\end{array}$ & $27 \%$ & $41 \%$ & $26 \%$ & $5 \%$ & $1 \%$ & $100 \%$ \\
\hline $\begin{array}{l}\text { The ability to switch } \\
\text { industries }\end{array}$ & $25 \%$ & $37 \%$ & $29 \%$ & $7 \%$ & $2 \%$ & $100 \%$ \\
\hline $\begin{array}{l}\text { The ability to expand by } \\
\text { international employment } \\
\text { opportunities }\end{array}$ & $21 \%$ & $32 \%$ & $34 \%$ & $11 \%$ & $3 \%$ & $100 \%$ \\
\hline $\begin{array}{l}\text { The right connections to } \\
\text { get a good job in the } \\
\text { future }\end{array}$ & $21 \%$ & $31 \%$ & $32 \%$ & $13 \%$ & $4 \%$ & $100 \%$ \\
\hline
\end{tabular}

Source: Global MBA Graduate Survey, 2006

Graduating students were also asked to indicate the organizational level in which they previously worked and what level they plan on entering upon degree completion. Figure 28 shows the results. (MBA.com, 2005a)

Graduating MBA students were moreover asked about their years of work experience prior to beginning their MBA degree. About two-fifths had worked 6 years or more, 37 percent worked between 3 and 6 years, 16 percent worked less than 3 years, and only 6 percent entered the full-time MBA program without any job experience. (MBA.com, 2005a) 
Figure 27. Level of Improvement in Skills and Abilities

\begin{tabular}{|c|c|c|c|c|c|c|c|}
\hline \multirow[b]{2}{*}{ Skill/Ability } & \multicolumn{7}{|c|}{$(n=6,139)$} \\
\hline & $\begin{array}{l}\text { A Great } \\
\text { Deal }\end{array}$ & $\begin{array}{l}\text { A Good } \\
\text { Amount }\end{array}$ & Some & A Little & $\begin{array}{l}\text { None at } \\
\text { All }\end{array}$ & $\begin{array}{l}\text { N/A- } \\
\text { Already } \\
\text { Profic- } \\
\text { ient }\end{array}$ & Total \\
\hline $\begin{array}{l}\text { Ability to think } \\
\text { strategically }\end{array}$ & $42 \%$ & $41 \%$ & $11 \%$ & $3 \%$ & $1 \%$ & $1 \%$ & $100 \%$ \\
\hline $\begin{array}{l}\text { Ability to think } \\
\text { globally }\end{array}$ & $33 \%$ & $39 \%$ & $18 \%$ & $6 \%$ & $2 \%$ & $2 \%$ & $10 \odot \%$ \\
\hline $\begin{array}{l}\text { Ability to integrate } \\
\text { information from a wife } \\
\text { variety of sources }\end{array}$ & $29 \%$ & $45 \%$ & $17 \%$ & $4 \%$ & $1 \%$ & $3 \%$ & $100 \%$ \\
\hline $\begin{array}{l}\text { Ability to think } \\
\text { analytically }\end{array}$ & $29 \%$ & $43 \%$ & $16 \%$ & $4 \%$ & $1 \%$ & $6 \%$ & $100 \%$ \\
\hline Leadership Skills & $29 \%$ & $41 \%$ & $20 \%$ & $6 \%$ & $2 \%$ & $3 \%$ & $100 \%$ \\
\hline $\begin{array}{l}\text { Ability to adapt/change } \\
\text { to new situations }\end{array}$ & $27 \%$ & $44 \%$ & $18 \%$ & 55 & $2 \%$ & $4 \%$ & $100 \%$ \\
\hline $\begin{array}{l}\text { Oral Communication } \\
\text { skills }\end{array}$ & $27 \%$ & $40 \%$ & $20 \%$ & $6 \%$ & $2 \%$ & $5 \%$ & $100 \%$ \\
\hline $\begin{array}{l}\text { Ability to make } \\
\text { decisions with } \\
\text { imperfect information }\end{array}$ & $26 \%$ & $46 \%$ & $20 \%$ & $5 \%$ & $1 \%$ & $2 \%$ & $10 \odot \%$ \\
\hline $\begin{array}{l}\text { Creative problem- } \\
\text { solving skills }\end{array}$ & $24 \%$ & $44 \%$ & $20 \%$ & $6 \%$ & $2 \%$ & $3 \%$ & $100 \%$ \\
\hline Quantitative Skills & $24 \%$ & $40 \%$ & $22 \%$ & $6 \%$ & $2 \%$ & $5 \%$ & $100 \%$ \\
\hline $\begin{array}{l}\text { Cultural sensitivity } \\
\text { and awareness }\end{array}$ & $24 \%$ & $34 \%$ & $23 \%$ & $9 \%$ & $4 \%$ & $7 \%$ & $10 \odot \%$ \\
\hline Interpersonal skills & $23 \%$ & $40 \%$ & $22 \%$ & $7 \%$ & $2 \%$ & $6 \%$ & $100 \%$ \\
\hline $\begin{array}{l}\text { Project management/ } \\
\text { implementation skills }\end{array}$ & $22 \%$ & $39 \%$ & $25 \%$ & $8 \%$ & $3 \%$ & $4 \%$ & $100 \%$ \\
\hline $\begin{array}{l}\text { Skills in corporate } \\
\text { ethical conduct }\end{array}$ & $21 \%$ & $37 \%$ & $24 \%$ & $10 \%$ & $4 \%$ & $5 \%$ & $100 \%$ \\
\hline $\begin{array}{l}\text { Initiative/risk-taking } \\
\text { ability }\end{array}$ & $20 \%$ & $43 \%$ & $24 \%$ & $7 \%$ & $3 \%$ & $3 \%$ & $100 \%$ \\
\hline $\begin{array}{l}\text { Written communication } \\
\text { skills }\end{array}$ & $19 \%$ & $37 \%$ & $24 \%$ & $9 \%$ & $3 \%$ & $9 \%$ & $100 \%$ \\
\hline $\begin{array}{l}\text { Recruiting, managing, } \\
\text { maintaining staff }\end{array}$ & $16 \%$ & $33 \%$ & $30 \%$ & $13 \%$ & $6 \%$ & $2 \%$ & $10 \odot \%$ \\
\hline $\begin{array}{l}\text { Technology skills for } \\
\text { your specialty }\end{array}$ & $15 \%$ & $28 \%$ & $28 \%$ & $13 \%$ & $8 \%$ & $8 \%$ & $100 \%$ \\
\hline
\end{tabular}

Source: Global MBA Graduate Survey, 2006

Figure 28. Job Level

\begin{tabular}{|l|c|c|}
\hline \multicolumn{1}{|c|}{ Job Level } & Pre-MBA & Post -MBA \\
\hline Entry Level & $24 \%$ & $9 \%$ \\
\hline Mid-Level & $56 \%$ & $49 \%$ \\
\hline Senior Level & $13 \%$ & $28 \%$ \\
\hline Executive Level & $4 \%$ & $9 \%$ \\
\hline Business Owner/self-employed & $3 \%$ & $5 \%$ \\
\hline Other & $1 \%$ & $1 \%$ \\
\hline Total & $100 \%$ & $100 \%$ \\
\hline
\end{tabular}

Source: MBA.com Registrants Survey, 2005 
Sometimes getting an MBA can serve as a catalyst to starting a new career or switching career fields. Figure 29 presents a classification of recent MBA graduates as either "career enhancers" or "career switchers" based on their responses to a survey regarding motivations. (MBA.com, 2005a)

Figure 29. Career Switching vs. Career Enhancement

\begin{tabular}{|l|l|}
\hline \multicolumn{1}{|c|}{ Response } & $(\boldsymbol{n}=\mathbf{4 , 7 5 7 )}$ \\
\hline Career enhancers & $51 \%$ \\
\hline Career switchers & $49 \%$ \\
\hline Total & $100 \%$ \\
\hline
\end{tabular}

Source: MBA.com Registrants Survey, 2005

Figure 30 shows what job functions recent graduates plan to assume upon completing their degree.(MBA.com, 2005a)

Figure 30. Job Functions

\begin{tabular}{|l|c|}
\hline \multicolumn{1}{|c|}{ Function } & $(\boldsymbol{n}=\mathbf{5 , 3 7 7})$ \\
\hline Finance/accounting & $35 \%$ \\
\hline Marketing/sales & $20 \%$ \\
\hline Consulting & $16 \%$ \\
\hline General management & $12 \%$ \\
\hline Operations/logistics & $8 \%$ \\
\hline Information technology/MIS & $6 \%$ \\
\hline Human Resources & $3 \%$ \\
\hline Total & $100 \%$ \\
\hline Source: MBA.com Registrants Survey, 2005
\end{tabular}

According to the Global MBA Survey of the classes of 2000 and 2001, finance and marketing were the most popular concentration areas. Strategy was tied with general management for third place.(Edgington \& Olkin, 2002) Figure 31 shows the results of the survey. 
Figure 31. Industry Group Pursued for Employment

\begin{tabular}{|c|c|c|c|c|}
\hline Industry Group & $\begin{array}{c}\text { Pre-MBA } \\
(n= \\
5,775)\end{array}$ & $\begin{array}{c}\text { Post - } \\
\text { MBA } \\
(n= \\
5,121)\end{array}$ & $\begin{array}{c}\text { \% Point } \\
\text { Difference } \\
*\end{array}$ & $\begin{array}{c}\% \\
\text { Chang } \\
\text { e }\end{array}$ \\
\hline $\begin{array}{l}\text { Finance/Accountin } \\
\mathrm{g}\end{array}$ & $18.7 \%$ & $25.5 \%$ & $6.8 \%$ & $36.5 \%$ \\
\hline $\begin{array}{l}\text { Products \& } \\
\text { Services }\end{array}$ & $21.3 \%$ & $22.5 \%$ & $1.2 \%$ & $5.4 \%$ \\
\hline Consulting & $14.5 \%$ & $17.9 \%$ & $3.3 \%$ & $23.0 \%$ \\
\hline High Technology & $17.5 \%$ & $11.2 \%$ & $-6.3 \%$ & $\begin{array}{l}-1 \% \\
36.1 \%\end{array}$ \\
\hline $\begin{array}{l}\text { Healthcare/ } \\
\text { Pharmaceuticals }\end{array}$ & $5.7 \%$ & $4.5 \%$ & $-1.2 \%$ & $20.7 \%$ \\
\hline Manufacturing & $7.2 \%$ & $7.6 \%$ & $.3 \%$ & $4.7 \%$ \\
\hline $\begin{array}{l}\text { Nonprofit/ } \\
\text { Government }\end{array}$ & $8.8 \%$ & $4.5 \%$ & $-4.3 \%$ & $\begin{array}{l}- \\
48.6 \%\end{array}$ \\
\hline Energy/Utility & $2.9 \%$ & $3.0 \%$ & $.2 \%$ & $6.6 \%$ \\
\hline Other & $3.4 \%$ & $3.3 \%$ & $-0.1 \%$ & $-2.6 \%$ \\
\hline Total & $100 \%$ & $100 \%$ & -- & -- \\
\hline
\end{tabular}

Source: Global MBA Graduate Survey, 2006

According to another survey, MBA graduates indicated that they work an average of fifty-one hours per week. (MBA.com, 2005a)

\section{B. EMPLOYERS}

Employers can choose to sponsor (through tuition assistance) an employee's further education or they can simply recruit MBA graduates as new hires. Either way, an MBA has to be important to corporations for students to spend the time, money and effort necessary to attain an MBA. Corporations essentially make the market for MBAs. As the corporate world demands more MBAs, they become more valuable. As demand decreases, so does their value. 
The employer's incentive for hiring MBAs is that they hope the MBAs will add value to their company. Added value comes from not only the skill set provided by an MBA grad but the intangible skills, such as fresh perspective and critical thinking skills.

\section{Who Hires MBAs?}

Among the top 30 schools, MBA graduates in 2006 received on average slightly more than two offers apiece from potential employers, up $20 \%$ over the previous year. In May of 2002, half of the nation's MBA grads were still looking for work. In May of 2006, only $14 \%$ were. (Lavelle \& Lehman, 2006)

From a survey of nearly 150 schools in 2006, Figure 32 depicts the average number of job offers received among MBA graduates who had received at least one job offer. (GMAC, 2006b)

Figure 32. Number of Job Offers

\begin{tabular}{|l|l|l|}
\hline \multicolumn{1}{|c|}{ Response } & \multicolumn{1}{|c|}{$\begin{array}{c}\text { Accepted } \\
\text { Offer }\end{array}$} & $\begin{array}{c}\text { Received Offers, } \\
\text { Not Yet Accepted }\end{array}$ \\
\cline { 2 - 3 }$(\boldsymbol{n}=\mathbf{1 , 4 9 0 )}$ & \multicolumn{1}{|c|}{$(\boldsymbol{n}=\mathbf{5 2 2})$} \\
\hline One job offer & $41 \%$ & $33 \%$ \\
\hline Two job offers & $26 \%$ & $34 \%$ \\
\hline Three job offers & $19 \%$ & $20 \%$ \\
\hline Four or more job offers & $15 \%$ & $13 \%$ \\
\hline Total & $100 \%$ & $100 \%$ \\
\hline Items in bold in the contingency table significantly affect the overall $x^{2}$ statistic \\
\hline
\end{tabular}

Source: Global MBA Graduate Survey, 2006

The traditional MBA employers have been firms in financial services, management consulting and consumer goods. They remain the biggest employers of MBAs to this date. The trend in recent years, however, has been for smaller firms in a variety of different industries, 
including high-tech start-ups and nonprofits, to hire them, and for graduates to start their own businesses. Government employers have joined the fray, too, often preferring MBAs to those with master's degrees in fields such as public administration, public health and international relations. The mix of employers varies from year to year, depending largely upon the health of their own industries.(Montauk, 2002) Employers are growing more diverse. According to Alysa Polkes, director of the Anderson School of Business's (UCLA) MBA Career Management Center, some promising industries that are up-and-coming for MBAs "include defense, government positions, and mid-cap firms that make durable goods." (Conley, 2002)

It is important to note that discussions of the employers of MBAs generally focus only on a graduate's first employer or those recruiters who are interested in hiring "freshly minted" MBAs. Almost no mention is generally made of the value of an MBA to employers 10 to 20 years down the road, when a graduate uses the MBA as a toplevel manager. These future mid-career and late-career employers are also important stakeholders for business schools and are, in effect, consumers of graduate management education or buyers of MBA graduates. These two different stakeholder groups, initial vs. future employers, however, clearly have different incentives. Initial employers seek value in the short term while future employers (and consequently MBA students themselves) expect MBA programs to provide education that is valuable over the long-term. Business schools consequently must make trade offs between the interests of these two groups and delicately balance training vs. education. 


\section{Why Do Employers Hire MBAs?}

In the broadest sense, the MBA degree represents a way of thinking, not just a set of financial skills and business knowledge. When asked why williams-Sonoma hires MBAs, HR manager Leslie Zurburg says, "We are looking for the $50,000 \mathrm{ft}$ view - the strategic thinker who takes an analytical approach. Operations managers who have risen through the company's ranks are experts at getting things done, Zurburg says. But MBAs from the outside can bring a fresh prospective. Critical thinking is not a course, per se. But this ability is woven into the MBA curriculum, which relies heavily on the case-study approach.

John Pantano, cofounder of Radianse, a startup that develops indoor global positioning products, hires MBAs because they have "professional training in problem solving. They know how to frame problems, ask questions and collect data."

In a 2006 survey conduct by the Graduate Management Admissions Council (GMAC), MBA recruiters were asked to indicate the skills and abilities they find attractive in MBA graduates. Figure 33 provides the results of this survey. The responses indicated that ability to think analytically and strategically are valued most by potential employers of MBAs. Those skills coming in close behind include quantitative skills, leadership skills, oral communication skills, creative problem-solving skills, the ability to integrate information, and project management/implementation skills. (GMAC, 2006b) 
Figure 33. Corporate Recruiters Survey 2006

\begin{tabular}{|c|c|}
\hline \multicolumn{2}{|c|}{ Skills/Abilities Recruiters Find Attractive in MBA Graduates } \\
\hline Skills/Abilities & $n=1,173$ \\
\hline Ability to think analytically & $78 \%$ \\
\hline Ability to think strategically & $71 \%$ \\
\hline Quantitative skills & $58 \%$ \\
\hline Leadership skills & $56 \%$ \\
\hline Oral communication skills & $53 \%$ \\
\hline Creative problem-solving skills & $52 \%$ \\
\hline Ability to integrate information & $51 \%$ \\
\hline Project management/implementation skills & $51 \%$ \\
\hline Interpersonal skills & $48 \%$ \\
\hline Written communication skills & $48 \%$ \\
\hline Ability to adapt/change to new Situations & $45 \%$ \\
\hline Work ethic & $38 \%$ \\
\hline Ability to make decisions with imperfect information & $35 \%$ \\
\hline Initiative/risk-taking ability & $33 \%$ \\
\hline Technological skills & $28 \%$ \\
\hline People management skills & $27 \%$ \\
\hline Cultural sensitivity and awareness & $22 \%$ \\
\hline Skills in corporate ethical conduct & $20 \%$ \\
\hline Other & $3 \%$ \\
\hline None of the above & $3 \%$ \\
\hline
\end{tabular}

Source: Corporate Recruiters Survey, 2006

3. From Which Schools Do Employers Hires MBAs?

When 940 recruiters were asked how they viewed the reputation of a school in a Corporate Recruiter Survey in 2002-03, seventy-five percent of the respondents listed experiential factors (i.e., the success of alumni they've previously hired and their own experiences dealing with the university). Over 50 percent listed the quality of the curriculum, and thirty-three percent listed the quality of the faculty. (0lkin, 2004) 
Karen Keasler, manager of IBM's Marketing Leadership Development Program indicates that she uses Business week and U.S. News and World Report rankings as kind of a filter to help decide where her recruiting efforts and resources can be best focused. "I'll generally cut it off at the top 30 schools from those lists," she says. "That doesn't mean I wouldn't consider a great candidate from a school that wasn't on those lists, but I have to spend my recruitment dollars carefully." (Wuorio, 2001)

"Getting an MBA is a big accomplishment." says Michelle Rapp, associate director of graduate student career services at Boston based Suffolk University. "But once you have it, you still have to compete for jobs. MBA students say, 'I want to interview at [a top ten consulting firm],' and I tell them, 'That company recruits only from top 10 schools.' You have to be realistic."

Top schools are brand names, agrees another recruiter. When you are competing against a brand name, "the burden of proof is on you," he says, even though core MBA courses remain remarkably similar across different institutions. Degree creep (meaning more and more people are getting MBA's to stay competitive) has devalued the degree. "The quality of the MBA program has become determinative."(Montauk, 2002)

Nonetheless, businesses are sending recruiters to more schools in search of MBAs from a broader range of outlets. Figure 34 shows that in a 2005 survey, 37 percent of the recruiters surveyed visited 7 or more schools to recruit MBAs. The data shows that the average number of schools that recruiters visit is 8 . 
Figure 34. Number of Schools which Company Visits to Recruit MBAs (GMAC, 2006a)

\begin{tabular}{|l|c|}
\hline \multirow{2}{*}{ Number of Schools } & Actual 2005 \\
\cline { 2 - 2 } & $(n=816)$ \\
\hline None & $17 \%$ \\
\hline 3 or less & $23 \%$ \\
\hline 4 , but less than 7 & $23 \%$ \\
\hline 7 or more & $37 \%$ \\
\hline Total & $100 \%$ \\
\hline Mean & $\mathbf{8}$ \\
\hline
\end{tabular}

Source: Corporate Recruiters Survey, 2006

\section{Why Do Some Employers Sponsor MBA Education?}

In one study of 2,570 employees, 55 percent indicated that their company provided education support and even reimbursement for career development.(GMAC, 2006c) In fact, about one in ten (11\%) of new MBA graduates state they are postponing their job search to fulfill contractual obligations with their current employer.(GMAC, 2006b)

Figure 35 demonstrates that the preference for corporations when reimbursing for or sponsoring MBA degrees is for part-time MBA programs. While many employers are willing to pay for graduate degrees for their employees, they frequently require some form of payback to the company . 
Figure 35. Corporate Reimbursement and Sponsorship Programs Among Firms That Hire MBAs (GMAC, 2006a)

\begin{tabular}{|l|c|c|c|}
\hline \multicolumn{1}{|c|}{ Statistic } & $\begin{array}{c}\text { Full-Time } \\
\text { MBA }\end{array}$ & $\begin{array}{c}\text { Part-Time } \\
\text { MBA }\end{array}$ & $\begin{array}{c}\text { Executive } \\
\text { MBA }\end{array}$ \\
\hline $\begin{array}{l}\text { Percentage } \\
\text { sponsored/reimbursed }\end{array}$ & $59 \%$ & $66 \%$ & $62 \%$ \\
\hline $\begin{array}{l}\text { Average Cost per } \\
\text { employee per year }\end{array}$ & $\$ 27,750$ & $\$ 21,327$ & $\$ 27,098$ \\
\hline
\end{tabular}

Source: Corporate Recruiters Survey, 2006

So what motivates employers to pay for graduate management education? "Research shows that companies that invest in education for their employees have a much higher retention rate than companies that don' $t$," notes Mark Allen, director of executive education at the Graziadio School of Business and Management at Pepperdine University. "It's almost counter intuitive. People who don't invest in education say, 'What if I pay to educate employees and they leave?' I answer, 'You're asking the wrong question. What if you don't educate them, and they stay?'" (Shinn, 2004b)

Even if an employer doesn't directly fund an employee's MBA education, the organization will often seek to re-hire its former employees after completion of the degree. Figure 36 shows that 26\% of MBA graduates received job offers from a current or previous employer.

Figure 36. Sources of Job Offers

\begin{tabular}{|l|c|}
\hline \multicolumn{1}{|c|}{ Source } & $(\boldsymbol{n}=\mathbf{2 , 0 0 1})$ \\
\hline An on-campus recruiter & $48 \%$ \\
\hline $\begin{array}{l}\text { An organization where you had an internship or } \\
\text { work project }\end{array}$ & $43 \%$ \\
\hline $\begin{array}{l}\text { An organization contacted in an off-campus job } \\
\text { search }\end{array}$ & $34 \%$ \\
\hline Current or previous employing organization & $26 \%$ \\
\hline An alumnus from your school & $11 \%$ \\
\hline Other & $7 \%$ \\
\hline
\end{tabular}

Source: Corporate Recruiters Survey, 2006 


\section{ANALYSIS}

\section{Students}

What is the true value of an MBA? The true value lies in the eye of the beholder. In the MBA industry, the beholders are the buyers who are the students and the employers who will hire the students.

With respect to the power of student as buyers, both the MBA programs and the students posses some leverage. While the students decide where to apply, the MBA programs ultimately can deny a student acceptance. However, the MBA programs have to attract students. The MBA is a product that people can live without. It is almost a luxury item. Only those willing and able to afford and complete the MBA program can purchase this item. So, even though the MBA programs can deny access to students they do not feel are worthy to participate in their programs, if students do not apply, they sell no product. It is for this reason that students and MBA programs share leverage. The MBA programs need the students as much as the students need the MBA programs.

That being said, there is obviously significant demand for the MBA degree from students. The reason they demand the degree is because they believe that it will enable them to receive greater opportunities in their career, receive a higher salary, or launch them into a new career. With the plethora of MBA programs to choose from, how do they decide? In many cases, students choose the highest ranked program to which they are accepted, although this may not always be the best financial decision. 
Students choose the highest ranked schools because, in their mind, the top-ranked schools give them the highest potential to fulfill their purposes for pursing the MBA in the first place. However, choosing to get a full-time MBA from the top-ranked schools does not necessarily offer the best ROI.

Given that a student has to give up a current salary and job position to pursue a full-time MBA in hopes of a future increase in salary, the opportunity costs during the "mean time" are usually high. In fact, after looking at the data provided in the chapter, a conclusion could be drawn that pursing an MBA degree at all is not worth what you have to give up.

Luckily, for those who cannot afford to quit their job for two years or who cannot afford to pay for the fulltime, two-year MBA program, there are alternatives that can limit the opportunity costs incurred while still offering an MBA. However, evidence shows that students choosing the part-time degree or executive degree are not as satisfied with their degrees as those who incurred the costs to earn the two-year, full-time degree. Also, those who choose to pursue part-time or distance learning degree miss out on the important classroom environment and/or on-campus networking that the resident degree provides.

From a purely financial value perspective, it is not clear that students benefit most from choosing a top-ranked school or even pursuing an MBA degree at all. Surveys suggest, however, that the MBA conveys significant intangible non-financial value. In particular, students perceive a greater value in a degree earned from a topranked school than they do from a lower- or non-ranked 
school. This perception fuels the competition for rankings that was mentioned in the previous chapter.

\section{Employers}

Employer preferences have a significant affect on market for MBAs. The employer's demand for MBAs dictates the job availability and salary range. Historical evidence suggests that the demand for MBAs is cyclical. In cycles of high demand salaries for MBAs are proportionally higher. The inverse is true in cycles of low demand. Regardless of the point in the cycle, employers are always seeking the best value to raise their company's performance by enhancing employees' abilities.

Best value is defined as the greatest benefit relative to cost. What employers define as "benefit," however, can range from training which allows employees to perform routine tasks more efficiently to higher-level education which emphasizes critical thinking and complex problem solving skills.

The lower end and least expensive end of the spectrum is focused on training. Costs for providing training for employees can be low and still provide positive return on investment. Certifying employees in relevant disciplines assures that the work force has the necessary tools to realize efficiencies. Examples of this end would be Lean Six Sigma Green Belt Training or Defense Acquisition University Certifications.

There are options in the middle range of the spectrum that can partially address both training and educational requirements. Primarily this intermediate range focuses on education and training delivery methods such as online 
courses, seminars, corporate universities or enrolling employees as part time students in non-resident MBA programs.

The high end of the spectrum is the most expensive option and focuses on education that will give employees the critical thinking and problem solving skills needed to take the company's performance to a new level of profitability. Employers who invest at this level make use of recruiters to hire MBA graduates from top schools.

Employers are not short on options to find the best value for their company's requirements. Potential students and current employees watch the hiring and advancement trends of their industry. In other words, they take their guidance from what employers are seeking. It is imperative for business schools to understand the dynamics of employer's expectations and to position themselves where their services are consistent with the needs of this important customer. The customer in this case, however, is not only the first organization to employ the MBA graduate, but also every future employer who will expect the graduate management education to bring value to its organization. 
THIS PAGE INTENTIONALLY LEFT BLANK 


\section{FACULTY}

\section{A. CATEGORIES OF BUSINESS SCHOOL FACULTY}

The most important suppliers to the graduate management education industry are the business school faculty who fill the teaching, research, and administrative roles with any MBA program. To understand the incentives, leverage, and importance of these key suppliers, one must first understand the different categories of business school faculty.

Generally speaking, faculty can be classified based on the nature of their employment relationship with their college or university. A typical faculty member's employment may be either full-time or part-time and, if full-time, either tenure-track or non-tenure-track. Finally, full-time tenure-track faculty member can be either tenured or untenured. While faculty categories and job titles can vary significantly across institutions, Figure 37 provides a general picture of the breakdown of faculty categories at a typical university.

Figure 37. Classification of Higher Education Faculty

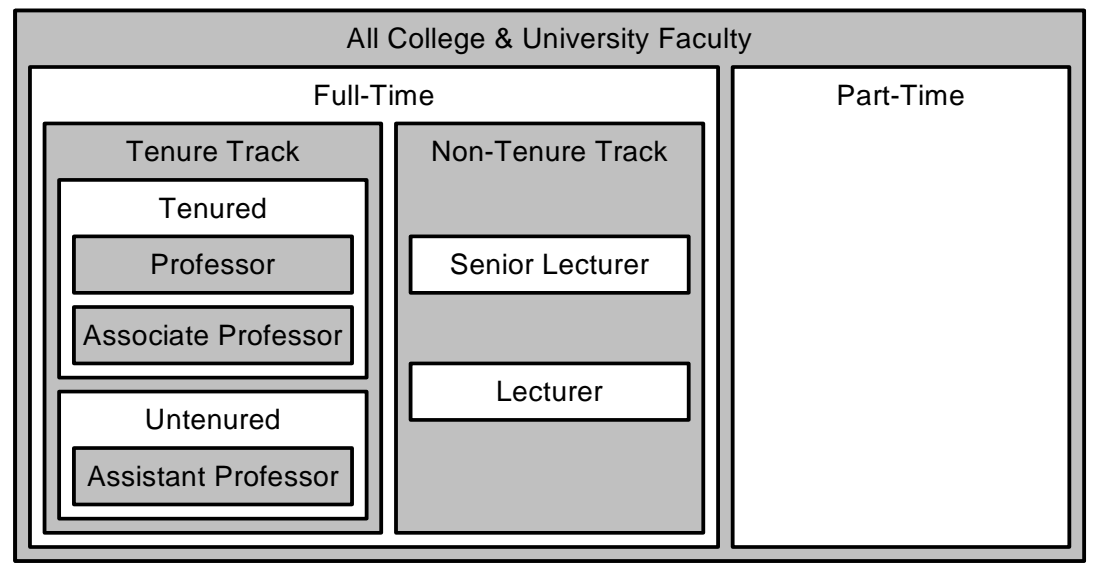


Full-time tenure-track (FTTT) faculty members typically follow the path of the "prototypical American scholar" (Boyer 1990) or "complete scholar" (Rice 1996) engaged in research, teaching and service. (Gappa et al., 2007) As the name implies, tenure-track faculty positions offer the potential for professional "tenure," which provides a guarantee of job security in that a tenured faculty member is granted the contractual right not to be fired without cause. A tenure-track faculty member has generally earned a doctorate or other terminal degree in his or her chosen field and usually carries the title of professor, associate professor, or assistant professor.

Full-time non-tenure track (FTNTT) faculty, in contrast, do not have the opportunity to receive professional tenure and are generally employed under contract-renewable appointments. Typical non-tenure track faculty positions carry titles such as lecturer or instructor and generally involve specialization, usually in teaching but sometimes in research. (Gappa et al., 2007) FTNTT faculty appointments represent a more flexible alternative to tenured appointments and are useful in hiring professionals with special expertise who would not necessarily seek or be qualified for tenure-track positions. Business schools, for example, hire senior "professors of practice," that is, people with extensive practical experience in their professions to augment tenure-track faculty in such curricular areas as accounting, where knowledge of practice is critical. (Gappa et al., 2007)

Part-time faculty (sometimes called "adjunct faculty") are hired temporarily to teach specific courses and are 
often paid on a per-course, per-segment, or even perstudent basis. Business education, in particular, relies heavily on part-time faculty due to the ready availability and value of practitioners who can bring current knowledge of their profession to the classroom. In fact, across all colleges and universities (including 2-year associate degree institutions), fully $51 \%$ of business faculty are employed on a part-time basis. Only 27 percent of parttimers, however, hold a doctorate or equivalent degree, although 54 percent have one or more master's degrees.

Figure 38. Faculty Employment Status by Institutional Category, Fall 2005

\begin{tabular}{|c|c|c|c|c|c|c|}
\hline & \multicolumn{3}{|c|}{ Tenure-Track Faculty } & \multicolumn{3}{|c|}{ "Contingent" Faculty } \\
\hline & Tenured & Untenured & $\begin{array}{l}\text { Total } \\
\text { Tenure- } \\
\text { Track }\end{array}$ & $\begin{array}{l}\text { Full- } \\
\text { Time } \\
\text { Non- } \\
\text { Tenure- } \\
\text { Track }\end{array}$ & $\begin{array}{l}\text { Part - } \\
\text { Time }\end{array}$ & $\begin{array}{c}\text { Total } \\
\text { Contingent }\end{array}$ \\
\hline $\begin{array}{c}\text { Doctoral/Re } \\
\text { search } \\
\text { Universitie } \\
\text { s }\end{array}$ & $37.3 \%$ & $14.6 \%$ & $51.8 \%$ & $18.6 \%$ & $29.5 \%$ & $48.2 \%$ \\
\hline $\begin{array}{c}\text { Master's } \\
\text { Degree } \\
\text { Universitie } \\
\text { s }\end{array}$ & $25.6 \%$ & $13.3 \%$ & $38.9 \%$ & $12.5 \%$ & $48.6 \%$ & $61.1 \%$ \\
\hline $\begin{array}{l}\text { Baccalaurea } \\
\text { te Colleges }\end{array}$ & $29.3 \%$ & $15.5 \%$ & $44.9 \%$ & $18.1 \%$ & $37.1 \%$ & $55.1 \%$ \\
\hline $\begin{array}{c}\text { Associate } \\
\text { Degree } \\
\text { Colleges }\end{array}$ & $14.7 \%$ & $5.4 \%$ & $20.1 \%$ & $14.3 \%$ & $65.6 \%$ & $79.9 \%$ \\
\hline $\begin{array}{c}\text { All } \\
\text { Colleges \& } \\
\text { Universitie } \\
\text { s }\end{array}$ & $26.1 \%$ & $11.3 \%$ & $37.4 \%$ & $15.6 \%$ & $47 . \odot \%$ & $62.6 \%$ \\
\hline
\end{tabular}

Source: John W. Curtis \& Monica F. Jacobe, "Consequences: An Increasingly Contingent Faculty," American Association of University Professors, 2006 
Taken together, part-time and non-tenure track faculty are identified as "contingent faculty" by the American Association of University Professors (AAUP). With this classification in mind, Figure 38 provides a breakdown of higher education faculty in the United States by employment status and institutional category.

\section{B. BALANCING TENURE-TRACK VS. "CONTINGENT" FACULTY}

During the last three decades, there has been a significant growth in the share of faculty members in American colleges and universities that are employed in part-time or full-time non tenure-track positions. This trend away from tenure-track appointments in favor of more contingent appointments is illustrated in Figure 39.

Figure 39. Trends in Faculty Employment Status, All Colleges \& Universities, 1975-2005

\begin{tabular}{|c|c|c|c|c|c|c|}
\hline \multirow{2}{*}{} & \multicolumn{3}{|c|}{ Tenure-Track Faculty } & \multicolumn{3}{c|}{ "Contingent" Faculty } \\
\cline { 2 - 7 } & Tenured & Untenured & $\begin{array}{c}\text { Total } \\
\text { Tenure-Track }\end{array}$ & $\begin{array}{c}\text { Full-Time Non- } \\
\text { Tenure-Track }\end{array}$ & Part-Time & $\begin{array}{c}\text { Total } \\
\text { Contingent }\end{array}$ \\
\hline 1975 & $36.5 \%$ & $20.3 \%$ & $56.8 \%$ & $13.0 \%$ & $30.2 \%$ & $43.2 \%$ \\
\hline 1989 & $33.1 \%$ & $13.7 \%$ & $46.8 \%$ & $16.9 \%$ & $36.4 \%$ & $53.3 \%$ \\
\hline 1995 & $30.6 \%$ & $11.8 \%$ & $42.4 \%$ & $16.7 \%$ & $40.9 \%$ & $57.6 \%$ \\
\hline 2005 & $26.1 \%$ & $11.3 \%$ & $37.4 \%$ & $15.6 \%$ & $47.0 \%$ & $62.6 \%$ \\
\hline
\end{tabular}

Source: John W. Curtis \& Monica F. Jacobe, "Consequences: An Increasingly Contingent Faculty," American Association of University Professors, 2006

While the data used in Figure 39 includes all educational fields, the increasing use of contingent 
faculty is also clearly evident in the field of business and management. The AACSB reports that the number of faculty in non-tenure-track positions at business schools has risen slowly but steadily in recent years, further noting that, "It seems clear that more schools are using adjunct or visiting professors to fill in open teaching slots, or they might be hiring faculty on a more temporary basis while they consider how to restructure staffs to create long-term solutions." (Leclair, 2004)

In fact, nearly one-quarter of all new hires at business schools in 2005 were in the instructor or lecturer rank. (AACSB, 2006a)

This widespread substitution of contingent faculty for tenure-track faculty is at least partially due to the growing financial pressures faced by higher education institutions, coupled with the lower cost and greater flexibility associated with contingent employment. (Ehrenberg \& Zhang Liang, 2004) This trend has potential negative consequences, however, in terms of both teaching and research.

With respect to teaching, Ehrenberg and Liang (2004) found that increases in the percentage of either part-time faculty or non-tenure track faculty were each associated with a reduction in graduation rates. (Ehrenberg \& Zhang Liang, 2004) In particular, they found that, other factors held constant, a 10 percentage point increase in the percentage of part-time faculty at a public academic institution was associated with a 2.65 percentage point reduction in the institution's graduation rate. Similarly, a 10-percentage point increase in the percentage of fulltime non-tenure-track faculty at a public college or 
university was associated with a 2.32 percentage point reduction in the institution's graduation rate. Particularly relevant for graduate management education, the magnitude of both of these effects was found to be greatest at a master's level institutions. (Ehrenberg \& Zhang Liang, 2004) The American Association of University Professors has similarly warned about the negative impact on educational quality that is inherent in the trend toward greater reliance on contingent faculty.

The negative research implications of this trend, on the other hand, are a consequence of the limited time generally available to contingent faculty for conducting research as well as the sometimes less significant preparation for academic research relative to their tenuretrack colleagues. First of all, faculty in contingent positions often carry heavy teaching loads with little time for academic research. (Gappa et al., 2007) Secondly, the percentage of faculty with doctorate degrees focused on research is significantly lower among contingent faculty than tenure-track-faculty. In addition, while AACSB accreditation standards allow for the use of non-doctoral "professionally qualified" faculty where suited to the schools mission, the requirements nonetheless specify ratios of doctorally qualified faculty relative to full staff. (AACSB, 2003)

\section{FACULTY CAREER PROGRESSION}

The career "ladder" and progression processes vary significantly between tenure-track and non-tenure-track faculty positions. Whereas the tenure-track career path is characterized by an "up or out" progression with the potential reward of tenure, the non-tenure-track career 
path is one in which promotion is not a requirement for retention but even the most senior faculty members may lack true job security.

First, consider Figure 40, which provides a generalization of the typical tenure-track faculty career path.

Figure 4๑. Generalization of the Tenure-Track Career Ladder

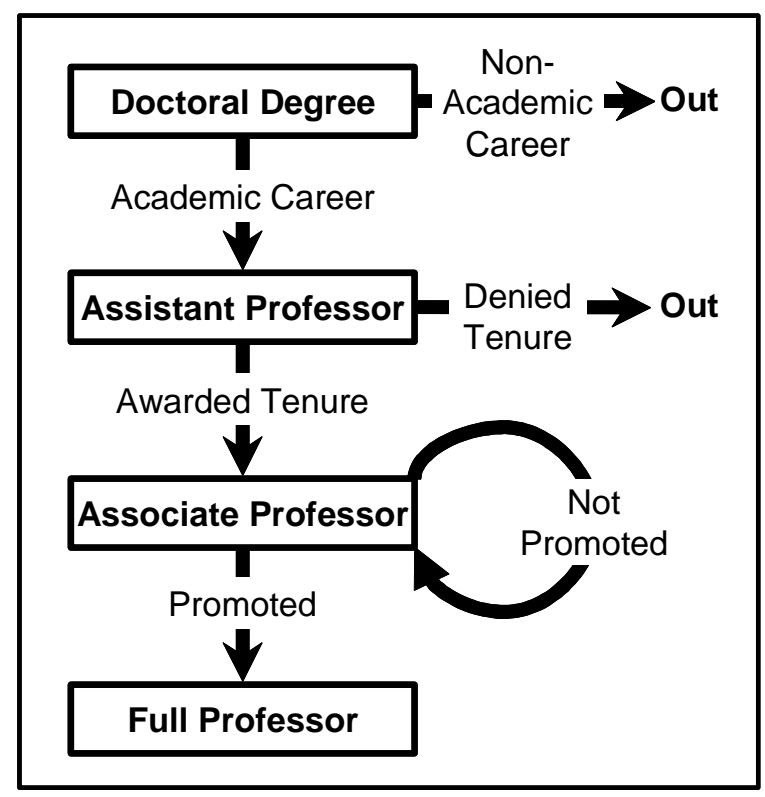

Virtually all tenure track appointments first require completion of a doctorate degree (Gappa et al., 2007) , which generally involves achievement of four primary milestones:

- approximately two years of coursework, which provides the foundation of research knowledge;

- a comprehensive exam or set of exams;

- an acceptable dissertation research proposal and consequent written dissertation; and 
- a successful oral "defense" of the dissertation to the faculty of the degree-granting institution(Briley, 1997)

Combined, the entire process of earning a doctorate degree in a business or management field requires an average of 7.7 years of "registered time" after receiving the baccalaureate degree, according to a 2004 survey of Earned Doctorates conducted by the National Opinion Research Center. (AACSB, 2006b) The same survey concluded that the average age at the time of achieving a doctorate in business or management was 35.7 years old. (AACSB, 2006b)

Initial tenure-track appointments are generally at the rank of assistant professor, a position which can be held for only a limited amount of time before the faculty member is considered for promotion to associate professor, a promotion which usually (but not always) comes with the granting of tenure. The limited number of years during which a junior faculty member is allowed to "qualify" himself or herself for promotion to a tenured position is commonly referred to as the "tenure clock" and, while highly variable across schools, is commonly around six years in the business and management fields. The tenuretrack career path is considered an "up or out" system in that, if denied tenure, a faculty member must subsequently leave the school, although he or she is often granted a one-year "grace period" in which to find another position. Tenured associate professors subsequently face the opportunity for promotion to "full" professor, although this promotion is frequently not an "up or out" decision. 
While the above description is an attempt to describe the typical tenure-track career progression, it is important to note that the standards, process, and timelines vary significantly across schools and across disciplines. For example, while both associate professor and full professor are commonly tenured positions, a 2006 survey by the AAUP found that $6.1 \%$ of faculty with the title of professor were, in fact, untenured $(4.9 \%$ being non-tenure-track positions) and $19.7 \%$ of faculty with title of associate professor were untenured (8.1\% being nontenure-track positions).(Thornton, 2006) At some business schools, in fact, associate professor is an untenured position and tenure is only granted at time of promotion to full professor, making this second promotion hurdle an additional "up or out" decision.

The non-tenure-track career ladder, on the other hand, could perhaps be described as providing potentially greater job security (relative to the tenure-track ladder) at the junior levels but less job security at the senior levels. A generalization of the non-tenure track career ladder is provided in Figure 41.

While it is not uncommon for lecturers or instructors to possess doctorate degrees, especially at higher-level research universities, it is often not a requirement for appointment to these non-tenure-track positions. Frequently, candidates with a master's degree combined with significant practitioner experience are employed as lecturers, especially in "professional" fields such as business. 
Figure 41. Generalization of the Non-Tenure-Track Career Ladder

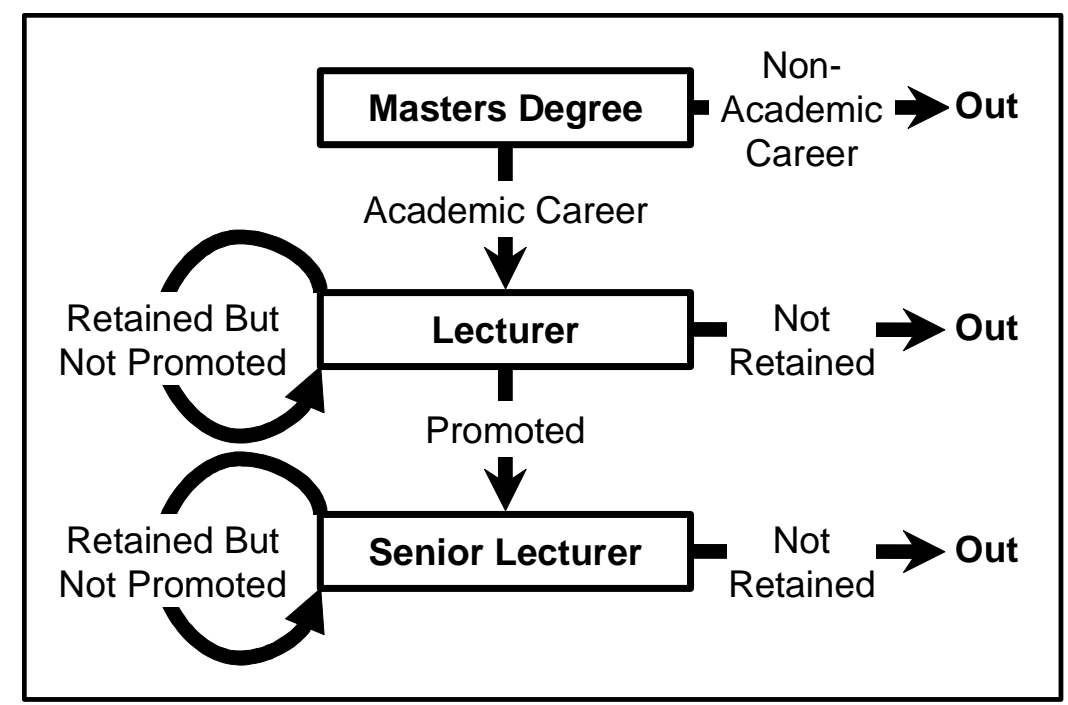

Non-tenure-track faculty do enjoy the job security associated with not confronting a "tenure clock" or "up or out" promotion process. NTTF appointment contracts can conceivably be renewed indefinitely, even without promotion to a higher position such as senior lecturer. On the other hand, non-tenure-track faculty do not have the opportunity to achieve the ultimate job security of tenure. Even the most experienced senior lecturers face the possibility of losing their job if, for example, the school decides to reduce staff to save money, a danger not faced by tenured faculty (who can only be fired for cause).

With these generalizations of faculty career ladders in mind, it is instructive to observe Figure 42, which provides an illustration of the general distribution of faculty at all U.S. higher education institutions among different ranks. Unfortunately, however, research by the AAUP (which generated the data in the table) does not break down the instructor/lecturer category by junior vs. senior ranks. 
Figure 42. Distribution of Faculty by Rank and Institutional Category, 2005-2006

\begin{tabular}{|c|c|c|c|c|c|}
\hline & Professor & $\begin{array}{c}\text { Associate } \\
\text { Professor }\end{array}$ & $\begin{array}{c}\text { Assistant } \\
\text { Professor }\end{array}$ & $\begin{array}{c}\text { Instructor / } \\
\text { Lecturer }\end{array}$ & $\begin{array}{c}\text { No } \\
\text { Rank }\end{array}$ \\
\hline $\begin{array}{c}\text { Doctoral/Research } \\
\text { Universities }\end{array}$ & $37.4 \%$ & $26.0 \%$ & $24.3 \%$ & $11.0 \%$ & $1.2 \%$ \\
\hline $\begin{array}{c}\text { Master's Degree } \\
\text { Universities }\end{array}$ & $29.0 \%$ & $27.0 \%$ & $29.7 \%$ & $12.9 \%$ & $1.4 \%$ \\
\hline $\begin{array}{c}\text { Baccalaureate } \\
\text { Colleges }\end{array}$ & $29.5 \%$ & $28.6 \%$ & $32.3 \%$ & $8.7 \%$ & $0.9 \%$ \\
\hline $\begin{array}{c}\text { Associate Degree } \\
\text { Colleges }\end{array}$ & $27.3 \%$ & $25.2 \%$ & $27.7 \%$ & $19.1 \%$ & $0.7 \%$ \\
\hline $\begin{array}{c}\text { All Colleges \& } \\
\text { Universities }\end{array}$ & $33.1 \%$ & $26.6 \%$ & $27.2 \%$ & $11.8 \%$ & $1.2 \%$ \\
\hline
\end{tabular}

Source: American Association of University Professors, "The Annual Report on the Economic Status of the Profession: 2005-06," March-April 2006.

\section{FACULTY ROLES: TEACHING VS. RESEARCH}

While business school faculty members fill numerous administrative and other roles, the primary responsibilities of the professors and lecturers at any institution generally reside in the two areas of teaching and research. While contingent faculty are often given incentives that require or encourage productivity in a particular dimension (usually teaching but sometimes research), tenure-track faculty are, at least on the face of things, encouraged to devote their efforts to both teaching and research.

Figure 43 illustrates where faculty members of all categories and all disciplines place themselves in the relative balance between teaching and research. It is of interest to note from the table that the largest group of faculty at both public and private universities was those 
who consider their primary interest to be in both teaching and research, "but leaning toward research."

Figure 43. Balance of Faculty Interest between Teaching and Research

\begin{tabular}{|l|c|c|}
\hline \multicolumn{1}{|l|}{$\begin{array}{l}\text { Percentage of faculty identifying role as their "primary } \\
\text { interest" }\end{array}$} & $\begin{array}{c}\text { Public } \\
\text { Universi } \\
\text { ties }\end{array}$ & $\begin{array}{c}\text { Private } \\
\text { Universi } \\
\text { ties }\end{array}$ \\
\hline Very heavily in teaching & $16.4 \%$ & $15.6 \%$ \\
\hline $\begin{array}{l}\text { In teaching and research, but leaning } \\
\text { toward teaching }\end{array}$ & $34.5 \%$ & $32.8 \%$ \\
\hline $\begin{array}{l}\text { In teaching and research, but leaning } \\
\text { toward research }\end{array}$ & $40.5 \%$ & $44.4 \%$ \\
\hline Very heavily in research & $8.6 \%$ & $7.2 \%$ \\
\hline
\end{tabular}

Source: Chronicle of Higher Education, Volume 50, Issue 1, Page A20

Students, who are the direct consumers of higher education, are often surprised to learn that faculty members consider their primary responsibility to be in the area of research rather than teaching. The greatest paradox of academic work is that most professors teach most of the time and large proportions of them teach all the time, but teaching is not the activity most rewarded by the academic profession or valued by the system at large. Trustees and administrators in one sector after another praise teaching, but reward research. (Gappa et al., 2007)

First of all, the hiring criteria used by business schools to judge new business doctorates looking for their first job have historically been based primarily on perceived research potential. Teaching potential has been a distant second. 
Second, the standards for promotion in general and tenure in particular, which in large part determine faculty activities, have traditionally defined faculty productivity in terms of research and publication. Service and teaching are risky priorities for faculty members seeking promotion or tenure at many institutions. As one young faculty member lamented, "As a new junior professor, I have come into the profession with a strong interest in research but an equally strong interest in serving students by helping them learn both inside and outside of the classroom. The attitude I'm receiving from all levels.... Is that research is what counts. If the other areas of service and teaching are lacking but research is strong, then promotions will follow."(Diamond \& Bronwyn E. Adam, 1993)

Third, greater research productivity simply correlates to higher faculty compensation. Evidence that research and publication significantly affect a faculty members' compensation level appears in a number of studies (Fairweather 1993; Fairweather, 1995; Hunnicutt, Taylor, and Keeffe, 1991; Kasten, 1984; Marchant and Newman, 1994, Prewit, Phillips, and Yasin, 1991).(Sutton \& Bergerson, ) Empirical studies of factors that affect individual faculty compensation typically have found that the best predictor of salary within an institution and within any rank are an individual's years of experience (Lewis, 1996). The number of articles published, however, is the second best predictor (Tuckman and Tuckman, 1976). Publication of scholarly journal articles enables individual faculty members to be promoted more rapidly and once the top rank is reached, publication enables an individual's compensation to continue to rise. Book publication, 
however, is not as rewarding as article publication. (Sutton \& Bergerson, ) Figure 44 shows the range of publications for full-time faculty members between 2001-2002.

Figure 44. Research Publications of Full-Time Faculty Members, 2001-2002

\begin{tabular}{|c|c|c|}
\hline \multicolumn{3}{|c|}{$\begin{array}{l}\text { Percentage of faculty with } \\
\text { professional writings published } \\
\text { publication in the last two years }\end{array}$} \\
\hline & $\begin{array}{c}\text { Public } \\
\text { Universities }\end{array}$ & $\begin{array}{c}\text { Private } \\
\text { Universities }\end{array}$ \\
\hline None & $19.6 \%$ & $18.1 \%$ \\
\hline 1 to 2 & $26.5 \%$ & $26.5 \%$ \\
\hline 3 to 4 & $27.3 \%$ & $28.0 \%$ \\
\hline 5 to 10 & $20.6 \%$ & $22.1 \%$ \\
\hline 11 to 20 & $4.7 \%$ & $4.7 \%$ \\
\hline 21 to 50 & $1.1 \%$ & $0.5 \%$ \\
\hline More than 50 & $0.2 \%$ & $0.1 \%$ \\
\hline
\end{tabular}

In addition, these empirical studies suggest that faculty rewards for teaching are minimal at best. Kasten (1984) reports that "Research on the relationship between teaching and rewards has been inconclusive," and cites eleven studies since 1970 that reached different conclusions about teaching and faculty rewards. (Sutton \& Bergerson, )

Finally, regardless of financial and career incentives, it should come as no surprise that tenure-track faculty members would be inclined towards research rather than teaching, given the fact that the most significant pre-requisite to becoming a tenure-track faculty member is completion of an appropriate doctorate degree. Most 
doctoral programs provide intensive preparation for highlevel research and very little preparation for classroom teaching. This is especially true among the most highly ranked programs. (Briley, 1997) Anyone who would choose to spend 5 to 9 years of their life in a business doctoral program must possess a strong affinity for research to begin with and would moreover leave the program with skills primarily suited for this particular task.

\section{The Nature of Business School Research}

If research is indeed so important to a tenure-track faculty member's career, it is important to inquire about what actually qualifies as research. While the definition of "academic research" varies significantly across institutions and discipline, AACSB accreditation standards provide some guidance as to the nature of research in the field of business scholarship.

The final report of the AACSB Task Force on Faculty Research defined research in the following way: "Research must be written, be subject to scrutiny and criticism by one's peers and extend the boundaries of current knowledge." The report went on to note that written material (such as some consulting reports) that is proprietary would not meet the definition and thus would not qualify as research. (Diamond \& Bronwyn E. Adam, 1993)

The AACSB accreditation standard requiring "intellectual contributions" requires business school faculty members to "make intellectual contributions on a continuing basis appropriate to the mission of the school. The outputs of intellectual contributions should be available for public scrutiny by academic peers or practitioners." The standard goes on to interpret the 
components of such intellectual contributions to include the creation of new knowledge (basic scholarship); the application, transfer, and interpretation of knowledge to improve management practice and teaching (applied scholarship) and the enhancement of the educational value of instructional efforts of the institution or discipline (instructional developments). (Diamond \& Bronwyn E. Adam, 1993)

While this AACSB standard asks faculty members to conduct research that is "appropriate to the mission of the school," it is important to note that untenured faculty members must be wary of conducting research that is too closely tied to the interests of a particular school or select set of schools. For example, while researching "instructional developments" such as case studies is highly valued at schools such as the Harvard Business School, the University of Virginia (Darden School of Business), and other select institutions which emphasize development of such teaching materials, such research is often devalued at most business schools which emphasize traditional journal publications in their hiring and promotion criteria. For this reason, junior faculty who have no guarantee of continued employment must be concerned about research that constitutes a "relationship-specific investment" in a particular institution or set of institutions and, consequently, untenured faculty must be more concerned about conducting research that will make them marketable to a broad set of potential employers.

\section{E. BUSINESS FACULTY SHORTAGE: DEMAND EXCEEDS SUPPLY}

While the number of master's degrees in business and management awarded in the U.S. has exploded in recent 
decades, the number of doctoral degrees in business and management has stagnated and even declined. The consequences of these two trends is that there is an increasing demand for qualified business faculty while at the same time there is a stagnating or decreasing supply of such faculty.

In 2002, the AACSB issued an ominous report, "Management Education at Risk," and in 2003, its Doctoral Faculty Commission issued its findings in "Sustaining Scholarship in Business Schools." Both of these reports issue warnings of the impending shortage of doctoral business faculty. (Fields, 2006)

Whereas there are more Master's Degrees granted each year in business than in any field other than education, the business and management field ranks only eighth in terms of the number of doctoral degrees conferred each year.(Chronicle, 2007) Figure 45 documents the number of master's degrees and doctoral degrees awarded in the U.S., as well as the ratio between the two numbers, from 1969 to 2004. Most troubling is the recent period from 1994-5 to 2001-2 when the number of doctoral degrees conferred declined by $17 \%$ while the number of master's degrees increased by $28 \%$. The ratio of master's degrees to doctoral degrees increases from 67.3 to 104.1 during this period. 
Figure 45. Degrees Conferred in Business and Management in the U.S. (1969-2004)

\begin{tabular}{|c|c|c|c|}
\hline Year & $\begin{array}{c}\text { Master's } \\
\text { Degrees }\end{array}$ & $\begin{array}{l}\text { Doctoral } \\
\text { Degrees }\end{array}$ & Ratio \\
\hline $1969-70$ & 21,561 & 620 & 34.8 \\
\hline $1970-71$ & 25,977 & 757 & 34.3 \\
\hline $1971-72$ & 30,028 & 859 & 35.0 \\
\hline $1972-73$ & 30,638 & 902 & 34.0 \\
\hline $1973-74$ & 32,172 & 919 & 35.0 \\
\hline $1974-75$ & 35,758 & 936 & 38.2 \\
\hline $1975-76$ & 42,054 & 900 & 46.7 \\
\hline $1976-77$ & 46,006 & 827 & 55.6 \\
\hline $1977-78$ & 47,837 & 823 & 58.1 \\
\hline $1978-79$ & 49,855 & 821 & 60.7 \\
\hline $1979-80$ & 54,484 & 753 & 72.4 \\
\hline $1980-81$ & 57,391 & 795 & 72.2 \\
\hline $1981-82$ & 60,763 & 815 & 74.6 \\
\hline $1982-83$ & 64,758 & 776 & 83.5 \\
\hline $1983-84$ & 66,150 & 929 & 71.2 \\
\hline $1984-85$ & 66,996 & 831 & 80.6 \\
\hline $1985-86$ & 66,689 & 934 & 71.4 \\
\hline $1986-87$ & 67,093 & 1,062 & 63.2 \\
\hline $1987-88$ & 69,230 & 1,063 & 65.1 \\
\hline $1988-89$ & 73,065 & 1,100 & 66.4 \\
\hline $1989-90$ & 76,676 & 1,093 & 70.2 \\
\hline $1990-91$ & 78,255 & 1,185 & 66.0 \\
\hline 1991-92 & 84,642 & 1,242 & 68.1 \\
\hline $1992-93$ & 89,615 & 1,346 & 66.6 \\
\hline $1993-94$ & 93,437 & 1,364 & 68.5 \\
\hline $1994-95$ & 93,809 & 1,394 & 67.3 \\
\hline $1995-96$ & 93,982 & 1,368 & 68.7 \\
\hline $1996-97$ & 97,619 & 1,336 & 73.1 \\
\hline $1997-98$ & 102,171 & 1,290 & 79.2 \\
\hline 1998-99 & 108,085 & 1,202 & 89.9 \\
\hline $1999-00$ & 112,258 & 1,196 & 93.9 \\
\hline $200 \odot-01$ & 116,475 & 1,180 & 98.7 \\
\hline $2001-02$ & 120,277 & 1,155 & 104.1 \\
\hline $2002-03$ & 129,178 & 1,257 & 102.8 \\
\hline $2 \odot \odot 3-\odot 4$ & 139,344 & 1,481 & 94.1 \\
\hline
\end{tabular}

Source: AACSB

The problem is not only that there are fewer business doctorates overall (at least relative to master's degrees), but also that there a fewer business doctorates from the 
top schools. For example, the percentage of doctorates produced by the AACSB-accredited institutions decreased to $84 \%$ in 1999-2000 from 92\% a decade earlier. (AACSB, 2003) Moreover, most of the top-25 business Ph.D. producers have shrunk their programs.(Zimmerman, 2001) "If you look at the list AACSB puts out on the top 10 producers and take out a couple of schools that don't really provide people for the academic market," noted University of Florida business dean, John Kraft, "you would see almost every major school has probably substantially reduced their Ph.D. program, and that's not going to change." (AACSB, 1998)

The driving forces behind this trend are budget constraints and changing priorities. Business schools have to find the resources to compete and the Ph.D. program is the place to cut. There are fewer resources being put into doctorate programs at the top schools primarily because of the competition for rankings in Business Week, the wall Street Journal and so on. "Much more effort is delivered to the MBAs and, of necessity, it has an effect on the training of Ph.D. students," noted Ross watts, chair of the Ph.D. program and professor of accounting and finance at the University of Rochester. "The faculty is just not as available as it used to be. They are putting a lot more effort into their MBA teaching, which isn't inappropriate, but the Ph.D. program becomes the stepsister." (AACSB, 1998)

Surveys by the AACSB on present and future faculty demand clearly indicate that a shortage is present and growing. In 2005, 400 schools surveyed (out of an estimated 1,500 U.S. schools offering business degrees) were recruiting for nearly 1,150 new doctorates at a time when 
only slightly more than 1,000 business doctorates are produced each year. These same 400 schools expected more than 3,100 new doctoral degree positions to open up in the next five years due to retirements and additions to existing staff.(Fairbank et al., 2005) The AACSB also estimated that the supply of business Ph.D.s would trail demand by 1,142 in 2007 and 2,419 in 2012. If more things go right than wrong, the AACSB noted that the shortage could be as few as 21 in 2007 and 334 in 2012. But, in a worst-case scenario, the shortfall may reach as many as 3,043 in 2007 and as many as 5,689 in 2012. (Fields, 2006)

\section{An Increasingly Foreign Candidate Pool}

The stagnation or decline in the development of new business doctorates is also accompanied by an increase in the number of foreign doctorates from U.S. schools. To make up for the shortage in the doctoral programs, many U.S. business schools have turned to foreign applicants, mainly from China and the former Soviet Union states. (Zimmerman, 2001) A study by the AACSB revealed that only 52.9 percent of students enrolled in U.S. business doctoral programs were U.S. citizens or had permanent Visas. The rest were non-U.S. citizens without permanent visas. (AACSB, 2006b) Michigan's Caul said that of 150 finance applications he looked at this year, 60 percent were from China alone. Duke's program had 120 applications this year and 156 were from foreign students, according to Jim Bettman, director of the Ph.D. program. Two-thirds of UCLA's applicants in the past three years have been from other countries.

So while business Ph.D. candidates from non-English speaking foreign countries are clamoring for American 
training in management, the concern is that these applicants may lack the English language skills necessary to walk into a classroom and immediately be an excellent teacher.(AACSB, 1998) These applicants may want to teach in American schools, but they are not easy to place on faculties because they lack fluency in English and ease with an MBA classroom style. (AACSB, 1998) Not surprisingly, the percentage of foreign-born faculty at U.S. business schools is increasing. Among the top 50 schools in the most recent Financial Times ranking, almost 31 percent of faculty, on average, were international. If the top 50 schools were to be grouped into U.S. school and non-U.S. schools, international faculty members would represent, on average, 25 percent and 42 percent, respectively, of the faculties. (AACSB, 2002)

\section{Competing with the Private Sector}

It is also important to note that the actual supply of new faculty to graduate business education is significantly lower than the production of business doctorates, as many of these graduates choose careers outside of academia. Figure 46 shows the different career choices for newly minted business and management doctorates as of 2004 . (AACSB, 2006b)

"Increasingly, more and more new Ph.D. graduates are going into the private sector," noted David Kidwell, dean at Minnesota's Carlson School of Business. "Those students provide a high level of theoretical and quantitative understanding of their disciplines and research, which is increasingly valuable to high end consulting firms. It's not a huge trend, but it is one that is increasing." (AACSB, 1998) 
Figure 46. Doctoral Career Choices of Business and Management Doctorates (2004)

\begin{tabular}{|l|c|}
\hline Postdoctoral Plans & Percent \\
\hline Postdoctoral Study & 4.1 \\
\hline Employment After Doctorate & 79.5 \\
\hline Educational Institution & 63.4 \\
\hline Industry/Business & 10.0 \\
\hline Government & 2.4 \\
\hline Nonprofit & 1.9 \\
\hline Other and unknown employment & 1.7 \\
\hline Unknown Postdoctoral plans & 16.4 \\
\hline $\begin{array}{l}\text { Source: Survey of Earned Doctorates, 2004, National } \\
\text { Opinion Research Center }\end{array}$ \\
\hline
\end{tabular}

The private sector, especially investment houses, technology companies and accounting firms also are looking for talent; and, they come armed with bigger budgets than business schools.(AACSB, 1998) In fact, a wall street company will readily pay two to four times as much as a bschool when they want what the Ph.D. has to offer. (AACSB, 1998)

Schools trying to reverse this trend offer higher starting salaries to new doctorates. So far, however, the percentage of doctorates choosing other careers has not declined, according to AACSB International. (Fields, 2006)

\section{Confronting the Shortage}

As one publication from the AACSB noted, "when it comes to attracting academically qualified faculty, we are deep in a seller's market of pandemic proportions." (Pulley, 2006) "When you look at supply and demand for business faculty," notes Sara Freedman, dean of Mississippi State University's College of Business and Industry, "there are not enough faculty coming through the traditional doctoral programs to staff our programs. Yet, the ability 
to recruit and retain faculty is central to strengthening programs." (Tyson, Spring 03 )

Andrew Policano, business dean at the University of Wiconsin-Madison, and other administrators believe they are on the front edge of doctoral faculty crunch. Last year, Wisconsin left six positions vacant out of a dozen it was seeking to fill. "We have continuing vacancies from one year to the next. We use visitors, people on sabbatical who will be teaching half time, faculty who are taking a full visit, or younger doctoral students who have just finished dissertations and aren't quite ready for permanent positions." Policano said.(AACSB, 1998)

Regardless of the actual number of Ph.D.S who may be in the pool, $b$-schools that consider themselves to be in $a$ "top" echelon are not going to hire someone for their faculty who does not meet their standards. Thus, educators say, it is "stars," young, middle-aged or older, who are being avidly pursued and wooed, not only by the top five, but by the top 10, 20, and 50. "Compared to five or six years ago, more schools than just the top five now think they are really good schools and they want to only go after the best," said Gautam Caul, associate dean and professor of finance at the University of Michigan. "The fact that there are vacancies left may not be so much an indication of potential candidates having gone down, but quality standards having gone up."

Stephen Lippmann, at the UCLA Andersen School of Business, has the same view. "We have openings and we would like to hire in a couple of fields. It's not that there aren't candidates to hire, it's that meeting our expectations is harder. Everybody wants to hire the same 
small set."(AACSB, 1998) Such intense competition for candidates at the upper tier schools takes talent away from the pool of candidates available to the second tier schools, which then forces less-endowed schools to reach down into the next tier, which reduces the pool the smaller schools have to choose from. "You just keep putting pressure further down in the pipeline," Policano said. (AACSB, 1998)

\section{Turning to Non-Business and Contingent Faculty}

In light of this competition for talent, universities have shifted their hiring techniques to cope with the shortage of qualified faculty. One avenue pursued has been to hire Ph.D.s from other disciplines and train them how to teach business courses. (Shinn, 2005)

Business schools have also increased hiring of nontenure-track "clinical professors" as a way to gain practitioner expertise on their faculty as well as economize on salaries.(AACSB, 1998) Primarily used to subsidize the increased teaching burden, these new hires typically devote little, if any, time to research and have no involvement with doctoral education programs. (Zimmerman, 2001) This can be a big concern because it makes it increasingly difficult for schools to maintain the research component of their missions. Once business schools lose their research leaders, they may have difficulty hiring worthy replacements. (Fields, 2006) If these schools are unable to maintain an adequate percentage of academically qualified faculty that perform research, they may also be unable to meet AACSB accreditation requirements. (Fields, 2006) 
Wisconsin and Illinois report that they are adding some clinical faculty, but are doing so very carefully in order to maintain the balance with the high quality research faculty a leading institution must have. Howard Thomas, dean at the University of Illinois, noted, "Clinical faculty still have the aura of second-class citizens among doctoral, tenure-track faculty, but I really see them as playing a key role in providing quality, cutting edge instruction." (AACSB, 1998)

To fill vacant positions, other schools have turned to adjunct or visiting faculty. UCLA, as well as stanford, Lippmann said, now hire five to 10 percent adjunct faculty. "These are excellent teachers with top quality experience. Thirty years ago we wouldn't have looked at such a person." (AACSB, 1998)

\section{F. FACULTY COMPENSATION}

Business school faculty members have traditionally enjoyed higher salaries than most of their counterparts in other academic fields, and the recent shortage in qualified business faculty has only increased this relative advantage in compensation. According to a 2006 survey of 226, 000 faculty members at 844 public and private four-year colleges and universities, faculty in the business and management field earned the third-highest average salaries among the 32 different fields classified, ranking behind only legal studies and engineering.

Figure 47 illustrates the average nine-month salary received by business school faculty, broken down by specific field and academic rank. Note that academic salaries are generally reported in nine-month terms because 
most faculty are only guaranteed nine-months of employment each year (some schools guarantee more, some less). Faculty commonly must seek additional internal or external funding for additional research or teaching for the remaining three months of the year (usually the summer). Given that most faculty do, in fact, find such funding, however, the values in Figure 47 significantly under-represent the average salaries actually earned on an annual basis.(Chronicle, 2006)

of particular note from Figure 47 is the fact that, overall, the average salary for new hires exceeds the salary for all faculty, especially at the tenured ranks. In some fields and ranks, the premium paid to new hires is quite significant. As the pool of high quality, freshly minted Ph.D.'s is diminishing; competition for associate and assistant professors is increasing. Institutions that can afford to bid are becoming more aggressive in recruiting faculty from other schools, inflating salaries beyond what some can afford.(AACSB, 1998)

Intense competition for new faculty is also reflected in increases in non-salary compensation (e.g. research funds and overload teaching). Business schools are also pursuing faculty at peer institution with job offers for family members, apartments and other perks.(AACSB, 1998)

Wisconsin's Policano sees it as a trickle down effect that begins with the top schools paying a higher price or offering more perks for a shrinking pool of faculty. Each next layer of schools then reaches down into another tier of quality, with diminishing quality form a smaller and smaller pool. (AACSB, 1998) 
Figure 47. Average 9-Month Salary by Business Field and Rank (2005-06) (\$ in $\odot \odot \odot^{\prime} \mathrm{s}$ )

\begin{tabular}{|c|c|c|c|c|c|c|c|c|}
\hline \multirow{2}{*}{ Field/Discipline } & \multicolumn{2}{|c|}{ Professor } & \multicolumn{2}{|c|}{$\begin{array}{l}\text { Associate } \\
\text { Professor }\end{array}$} & \multicolumn{2}{|c|}{$\begin{array}{l}\text { Assistant } \\
\text { Professor }\end{array}$} & \multicolumn{2}{|c|}{$\begin{array}{l}\text { Lecturer } \\
\text { Instructor }\end{array}$} \\
\hline & All & $\begin{array}{l}\text { New } \\
\text { Hires }\end{array}$ & All & $\begin{array}{l}\text { New } \\
\text { Hires }\end{array}$ & All & $\begin{array}{c}\text { New } \\
\text { Hires }\end{array}$ & All & $\begin{array}{l}\text { New } \\
\text { Hires }\end{array}$ \\
\hline $\begin{array}{l}\text { Finance / Banking } \\
\text { / Real Estate / } \\
\text { Insurance }\end{array}$ & 134.0 & 142.3 & 107.1 & 126.4 & 109.0 & 111.0 & 60.9 & 60.0 \\
\hline $\begin{array}{l}\text { Production/ } \\
\text { Operations } \\
\text { Management }\end{array}$ & 118.2 & 159.2 & 95.9 & 109.9 & 92.6 & 87.5 & 58.7 & 44.8 \\
\hline $\begin{array}{l}\text { Accounting / } \\
\text { Taxation }\end{array}$ & 118.1 & 135.7 & 98.3 & 111.4 & 98.1 & 104.2 & 54.6 & 51.4 \\
\hline Marketing & 117.6 & 110.8 & 93.7 & 95.5 & 90.5 & 89.3 & 56.5 & 55.3 \\
\hline $\begin{array}{l}\text { Quantitative } \\
\text { Methods/Operations } \\
\text { Research/Statistic } \\
\text { S }\end{array}$ & 117.4 & -- & 91.1 & 119.3 & 81.4 & 75.1 & 50.1 & 51.6 \\
\hline $\begin{array}{l}\text { Management / } \\
\text { Behav. Science/ } \\
\text { International Bus. } \\
\text { / strategic Mgmt. }\end{array}$ & 115.3 & 110.6 & 91.8 & 99.1 & 87.8 & 88.9 & 52.3 & 50.2 \\
\hline CIS / MIS & 114.1 & 85.6 & 94.8 & 94.3 & 91.7 & 87.4 & 52.3 & 47.4 \\
\hline $\begin{array}{l}\text { Economics / } \\
\text { Managerial } \\
\text { Economics }\end{array}$ & 107.3 & 116.7 & 79.1 & 101.4 & 72.9 & 71.9 & 51.7 & 52.8 \\
\hline $\begin{array}{l}\text { All disciplines } \\
\text { (including those } \\
\text { not named above) }\end{array}$ & 117.1 & 121.1 & 93.7 & 105.0 & 91.0 & 91.8 & 53.6 & 50.8 \\
\hline
\end{tabular}

Source: AACSB International - ref 214. 
"It's crisis time for the public universities," says Policano. "We are on a razor's edge and at any given moment, if the private schools with heavy endowments come and offer support for top faculty it would be very difficult to compete." (AACSB, 1998)

Spiking salaries for doctorally qualified new hires has created a new problem: salary inversion.(Fields, 2006) UCLA, for example, is "very aggressive," Lippmann said in recruiting rookies, often paying them more than three, four, and five-year faculty. "Not long ago, my 12 month salary was lower than a rookie's and I'm a chaired professor." (AACSB, 1998)Soon, it may not be uncommon for an associate professor with ten years of experience and a solid record of teaching, research, and service to earn $\$ 10,000$ less than a new hire just brought on board.(Fields, 2006) Illinois' Thomas noted that, "People now retiring often have much lower salaries than those of starting professors." (AACSB, 1998)

It does not stop with new hires. It affects the experienced faculty as well. Rising salaries for new hires has encouraged experienced faculty to move to different institutions to receive pay raises of their own, and thus the market continues to stay extremely competitive. (Leclair, 2004) This does not bode well for schools because the senior faculty who relocate are replaceable only at a significant premium over their current salaries, even if the successors are far more junior. (AACSB, 2003)

\section{G. FACULTY CAREER CHOICE}

Given that most business school faculty members could be earning considerably greater compensation in the private 
sector, it is important to understand why they would choose an academic career in the first place. While not specific to business schools, Figure 48 provides the results of a survey of higher education faculty members regarding why they decided to pursue an academic career. While not surprising that "intellectual challenge" was the number one reason for pursuing an academic career, it is perhaps revealing that the next four reasons all relate to either intellectual or professional freedom.

Figure 48. Top Reasons Faculty Pursue an Academic Career

\begin{tabular}{|c|c|c|}
\hline \multicolumn{3}{|c|}{$\begin{array}{l}\text { Percentage of faculty identifying reason as "very } \\
\text { important" in decision to pursue an academic career }\end{array}$} \\
\hline & $\begin{array}{c}\text { Public } \\
\text { Universi } \\
\text { ties }\end{array}$ & $\begin{array}{c}\text { Private } \\
\text { Universi } \\
\text { ties }\end{array}$ \\
\hline Intellectual challenge & $88.5 \%$ & $89.2 \%$ \\
\hline $\begin{array}{l}\text { Freedom to pursue scholarly/teaching } \\
\text { interests }\end{array}$ & $83.0 \%$ & $82.1 \%$ \\
\hline Intellectual freedom & $81.4 \%$ & $79.4 \%$ \\
\hline Autonomy & $76.7 \%$ & $77.4 \%$ \\
\hline Flexible schedule & $67.6 \%$ & $66.3 \%$ \\
\hline Opportunities for research & $61.1 \%$ & $61.4 \%$ \\
\hline Opportunities for teaching & $60.0 \%$ & $60.4 \%$ \\
\hline $\begin{array}{l}\text { Opportunity to influence social } \\
\text { change }\end{array}$ & $22.3 \%$ & $20.0 \%$ \\
\hline prestige/professional & $19.5 \%$ & $19.5 \%$ \\
\hline
\end{tabular}

Source: Chronicle of Higher Education, Volume 50, Issue 1, Page A20

It is the importance of intellectual freedom in higher education that motivates the institution of academic tenure, which provides a level of job security, which is quite rare in the American economy. Academic tenure, it is 
argued, protects established teachers and researchers when they dissent from prevailing opinion or openly disagree with authorities within or outside the school. Thus academic tenure is similar to the lifetime tenure that protects some judges from external pressure. Without job security, the scholarly community as a whole might favor "safe" lines of inquiry. (Wikipedia, 2007)

It is important to note, however, that universities also have economic rationales for adopting tenure systems. First, job security and the accompanying autonomy are significant employee benefits; without them, universities might have to pay higher salaries or take other measures to attract and retain faculty. Second, junior faculty are driven to establish themselves by the high stakes of the tenure decision (i.e., lifetime tenure vs. job loss), arguably helping to create a culture of excellence within the university. Finally, tenured faculty may be more likely to make "relationship-specific investments" of their time and energy in improving the universities where they expect to remain for life; they may also be more willing to hire, mentor and promote talented junior colleagues who could otherwise threaten their positions. Many of these rationales resemble those for senior partner positions in law and accounting firms. (Wikipedia, 2007)

While the number two and three reasons that faculty choose academic careers in Figure 48 are associated with intellectual freedom, the number four and five reasons are clearly associated with professional or lifestyle freedom. Academic positions generally do not require faculty to "clock in and out," to bill by the hour, to work normal business hours, or even to be physically located on campus 
when conducting their work (other than the actual time spent in the classroom). Many faculty members, especially full-time faculty with tenure, operate with a minimum of supervision from their institutions and outside agencies, structuring their work as they want. (Gappa et al., 2007) A faculty career is hence one that is judged on product (research published, classes taught well, etc.), rather than process.

The importance that academic faculty place on professional freedom was conveyed quite succinctly by NPS Associate Professor David Henderson recently when he noted that, "The reason that many of us became academics is because we get to choose when and where we do our 70 hours of work a week." (Quoted by Associate Professor Peter Coughlan during interview.) Professor Henderson's quote captures well the tradeoff that faculty make when they choose an academic career: They are willing to work at jobs that require them to put in as much as 70 hours per week, but in return they expect to be given the freedom to work when, where, and how they see fit.

\section{H. FACULTY JOB SELECTION}

Perhaps not surprising given the "up or out" nature of tenure-track positions, business schools are constantly in pursuit of new faculty. From 2002 and 2005, between seven and nine percent of all full-time faculty in U.S. business schools were new hires, with schools averaging around four new faculty members per year. (AACSB, 2006a; LeClair, 2004; Shinn, 2005) Almost 60 percent of new hires at business schools were experienced - that is, neither new doctorates nor candidates for doctorates known as "all but dissertation" (ABD's). (LeClair, 2004) 
For a view of the job selection process from the faculty perspective, Hunt (2004) conducted a survey among 207 business school faculty members who had recently accepted employment at their first academic position (all had registered in the Academy of Management online job placement services). Respondents had contacted an average of 31.1 schools in their job search and received an average of 3.8 on-campus interviews. (Hunt, 2004) Male respondents reported 2.73 job offers and females had an average of 2.19 job offers. Those who ended up accepting a position at a doctoral (i.e. research-oriented) school had received an average of 2.67 offers, while those at non-doctoral schools had 2.52 offers. (Hunt, 2004)

\section{Why Faculty Choose to Work at a Particular School}

To assess the priorities of business and management faculty when selecting among potential academic employers, Hunt asked the respondents to his survey to rate the importance of 32 different factors on the decision to accept employment at their current school.(Hunt, 2004) Results for the 20 most important factors are given in Figure 49, separated between respondents at doctoral and non-doctoral schools.

Among new faculty at both doctoral and non-doctoral institutions, teaching load (i.e. minimization of the number of different courses, segments, and/or terms that the faculty member would be required to teach) was the most important factor in determining which academic position to accept among competing offers. Moreover, teaching load was the number one factor by a quite significant margin among faculty at doctoral institutions. 
Figure 49. Importance of Factors in Accepting a Business School Faculty Position ( 7 point scale, $7=$ extremely important, 1=not at all important)

\begin{tabular}{|c|c|c|c|c|}
\hline \multirow[b]{2}{*}{ Variable } & \multicolumn{2}{|c|}{$\begin{array}{l}\text { Doctoral } \\
\text { Schools }\end{array}$} & \multicolumn{2}{|c|}{$\begin{array}{c}\text { Non- } \\
\text { Doctoral } \\
\text { Schools }\end{array}$} \\
\hline & Mean & Rank & Mean & Rank \\
\hline $\begin{array}{l}\text { Teaching load } \begin{array}{l}\text { (number of } \\
\text { segments, terms, etc.) }\end{array} \\
\text { etcourses, }\end{array}$ & 6.41 & 1 & 6.03 & 1 \\
\hline Likelihood of obtaining tenure & 6.00 & 2 & 5.78 & 3 \\
\hline Compatibility with other faculty & 5.93 & 3 & 5.95 & 2 \\
\hline Spouse's evaluation of area & 5.63 & 4,5 & 5.48 & 6 \\
\hline $\begin{array}{l}\text { Funding for research, research } \\
\text { assistants, \& research time }\end{array}$ & 5.63 & 4,5 & 5.20 & 12 \\
\hline $\begin{array}{l}\text { Criteria used for promotion and } \\
\text { tenure decisions }\end{array}$ & 5.56 & 6,7 & 5.73 & 4 \\
\hline Funding for travel to meetings & 5.56 & 6,7 & 5.40 & 7 \\
\hline Prestige of school or department & 5.44 & 8 & 4.53 & 22 \\
\hline $\begin{array}{l}\text { Background, interests, \& research } \\
\text { orientation of the faculty }\end{array}$ & 5.37 & 9 & 4.58 & 21 \\
\hline Library and computer facilities & 5.30 & 10 & 5.23 & 11 \\
\hline Opportunity to teach desired courses & 5.19 & 11 & 5.63 & 5 \\
\hline Base salary & 5.15 & 12 & 5.30 & 9 \\
\hline Compatibility with department head & 5.12 & 13 & 4.90 & 12 \\
\hline Existence of Ph.D. program & 4.96 & 14 & 2.44 & 32 \\
\hline Fringe benefits package & 4.85 & 15 & 4.63 & 17,18 \\
\hline Geographic location of school & 4.74 & 16,17 & 5.33 & 8 \\
\hline $\begin{array}{lll}\text { Availability } & \text { of } & \text { supplementary } \\
\text { research grants } & & \\
\end{array}$ & 4.74 & 16.17 & 4.10 & 25,26 \\
\hline Quality and motivation of students & 4.70 & 18 & 4.75 & 14 \\
\hline Cost of living in area & 4.67 & 19 & 4.63 & 17,18 \\
\hline $\begin{array}{l}\text { Physical facilities (e.g. } \\
\text { offices, classrooms etc.) }\end{array}$ & 4.50 & 20 & 4.60 & 19,20 \\
\hline
\end{tabular}

Source: Table 2 from ref 202 pg 60 \& 61

It is also of interest to note from Figure 49 that salary was only the $12^{\text {th }}$ most important decision factor among new faculty at doctoral institutions and the $9^{\text {th }}$ most important factor among new faculty at non-doctoral institutions. As William Nichols, associate dean at University of Norte Dame's Mendoza College of Business, 
noted, "Money alone doesn't drive faculty recruitment, but it allows you to have a conversation with some of the best faculty in the United States."(Tyson, Spring 03)

Additional insight into job selection criteria among faculty was provided in research conducted by Trower (2002). Trower's investigation into the job choices of new doctoral-degree recipients and new faculty in the first or second year of employment showed that faculty as well new Ph.D graduates prefer tenure-track appointments for the economic security and academic status they provide. Respondents also indicated, however, that they would select non-tenure-track appointments for the sake of geographical location, flexibility, and balance between teaching and research. (Gappa et al., 2007)

\section{Relocating to New Positions}

Given the fact that academic careers are often characterized by a number of "stops" at different institutions, it is important to examine the costs and incentives for faculty when they switch employers.

First of all, academic careers have special switching costs associated with the tenure process. Certainly, tenured faculty members are generally unlikely to switch employers and give up the job security of tenure unless their new employer is willing to offer them tenure as well. offering immediate tenure to a faculty member at another institution, however, might be a difficult pill to swallow for the offering school, given that the faculty at the new institution must effectively choose a colleague for life despite having perhaps never worked closely with the individual. Untenured faculty on the tenure-track face a different sort of switching cost: The cost of starting 
over. When an assistant professor moves from one institution to another, his or her "tenure clock" is often either restarted or at least set back a number of years, pushing farther away the possible attainment of the "Holy Grail" of tenure.

In light of these switching costs, Eaton and Hunt (2002) examined the reasons that faculty decide to relocate. Factors of importance were similar to those of new PhDs in Figure 49. Most relocating faculty members left their previous employment voluntarily. The main reasons were incompatibility with other faculty and spouse's evaluation of the area. However, a number of respondents indicated that they were not dissatisfied, but had received an outstanding offer from another university. Those who left involuntarily either did not receive tenure or thought they would not in the future. (Hunt, 2004)

Additional insight is provided from a survey of faculty members conducted by the U.S. Department of Education. In responding to a question about the most important characteristics of a new job if a faculty member were to leave his or her current institution, tenured and tenure-track faculty replied that tenure was very important (83 percent), followed by job security in general (71 percent), and geographical location ( 70 percent). These faculty members also placed a high priority on spousal employment (69 percent)(Gappa et al., 2007)

\section{FACULTY JOB SATISFACTION}

College and university faculty, as a whole, exhibit remarkably high levels of career and job satisfaction. In their responses to the 2004 National survey of 
Postsecondary Faculty, faculty members showed a high degree of satisfaction (87.5 percent) with their jobs overall, regardless of appointment, time base, institutional type, gender, or ethnic background.(Gappa et al., 2007) Analysis of several Carnegie Foundation for the Advancement of Teaching surveys conducted between 1969 and 1997 shows that for decades full-time faculty members have remained generally satisfied with their career choices and their institutions. Very few have indicated that they would change their profession if they had it to do over again. They have retained their positive attitudes about their academic careers even though their workloads have escalated and their salaries have not always kept pace with inflation. (Gappa et al., 2007)

Moreover, the previously mentioned survey of recently hired business school faculty members conducted by Hunt indicated high levels of confidence that these new hires had indeed selected the right faculty position. On a scale of 1 to 7 , with 7 representing that one was sure that he or she had chosen the correct offer, respondents at doctoral schools averaged 6.04, while the average for those at nondoctoral schools was 6.19. (Hunt, 2004)

The aspects of their career or particular academic position that faculty find most satisfying are illustrated by the survey results in Figure 50. "Autonomy and independence" ranks as the best aspect of their job by a large margin for faculty at both public and private universities. 
Figure 50. Top Reasons Faculty Are Satisfied with a Particular Academic Position

\begin{tabular}{|c|c|c|}
\hline \multicolumn{3}{|l|}{$\begin{array}{l}\text { Percentage of faculty identifying } \\
\text { "satisfactory" or "very satisfactory" }\end{array}$} \\
\hline & $\begin{array}{l}\text { Public } \\
\text { Universi } \\
\text { ties }\end{array}$ & $\begin{array}{c}\text { Private } \\
\text { Universi } \\
\text { ties }\end{array}$ \\
\hline Autonomy and independence & $88.4 \%$ & $89.8 \%$ \\
\hline Job security & $80.0 \%$ & $81.3 \%$ \\
\hline Opportunity to develop new ideas & $79.6 \%$ & $82.7 \%$ \\
\hline Overall job satisfaction & $73.6 \%$ & $78.7 \%$ \\
\hline $\begin{array}{l}\text { Professional relationships with other } \\
\text { faculty members }\end{array}$ & $72.4 \%$ & $75.3 \%$ \\
\hline Competency of colleagues & $72.1 \%$ & $76.4 \%$ \\
\hline Opportunity for scholarly pursuits & $70.5 \%$ & $73.3 \%$ \\
\hline Teaching load & $62.5 \%$ & $66.0 \%$ \\
\hline office/lab space & $61.4 \%$ & $70.2 \%$ \\
\hline $\begin{array}{l}\text { Social relationships with other faculty } \\
\text { members }\end{array}$ & $57.1 \%$ & $63.0 \%$ \\
\hline Relationships with administration & $57.1 \%$ & $61.3 \%$ \\
\hline $\begin{array}{l}\text { Visibility for jobs } \\
\text { institutions/organizations }\end{array}$ & $49.5 \%$ & $52.8 \%$ \\
\hline Salary and fringe benefits & $46.6 \%$ & $56.3 \%$ \\
\hline Quality of students & $44.0 \%$ & $70.0 \%$ \\
\hline
\end{tabular}

Source: Chronicle of Higher Education, Volume 50, Issue 1, Page A20

\section{Lower Satisfaction Among Untenured Tenure-Track Faculty}

The overall high level of job satisfaction among academic faculty may mask lower levels of satisfaction among particular groups, however. Indeed, a survey of untenured tenure-track faculty members at six research universities led to less positive results. In this case, 25 percent responded that they were either dissatisfied of very dissatisfied with their college or university as a place to work (Trower and Bleak 2004). This population of early career faculty in highly competitive environments may have included a significant proportion of individuals who 
were in the process of determining whether they really wanted to continue building their careers in the academy.

New tenure-track faculty members enter their academic careers because they believe that faculty work involves autonomy, flexibility, freedom to pursue academic interests, and opportunities to serve society through education. Unfortunately, what early career faculty members hope for does not fully match what they actually experience (Rice, 1996b; Rice, Sorcinelli, and Austin, 2000). Olsen (1993) found that satisfaction with faculty work actually declined over the first several years of a tenure-track appointment, and that this decline was accompanied by an increase in job-related stress attributed to conflicts involving time and work-life balance.(Gappa et al., 2007)

Early-career faculty have reported finding the tenure process and its expectations mystifying (Rice, Sorcinelli, and Austin, 2000; Austin and Rice 1998). Over and over again, researchers on the topic have heard comments such as "Everything is so vague, ambiguous, and illusive" or "There is no steady, reliable feedback" or "I cannot get a good read on what it takes to get tenure" (Rice, Sorcinelli, and Austin, 2000). One new faculty member succinctly referred to the tenure process as "archery in the dark" (Rice, 1996b, p.31).

For many untenured tenure-track faculty members, the rigidity of the tenure timeline is the most critical aspect of the tenure process (Austin and Rice, 1998). As performance expectations continue to increase, funding opportunities are decreasing, and this gap is causing greater competition for grants to support research in some fields. Academic journals' review processes and schedules 
often result in long delays before authors are notified about receipt of their work, much less about its acceptance, and there may be even longer delays until an accepted manuscript appears in print.(Gappa et al., 2007)

The end result of the tenure process is that "people stagger to the end of the tenure review" (Tierney and Bensimon, 1996, p. 73). If they attain tenure, they feel relieved rather than elated. One respondent, the first to have gained tenure in his school in ten years, said, "It's been dehumanizing ... I'm disheartened by the whole thing"; another commented, "I've got it. I will never give it up, because I would never put my family through that again. Never" (Tierney and Bensimon, 1996. p.73).

2. Sacrificing Family and Personal Life for the Academic Career

Many faculty members report that they face constant pressure to turn their attention in too many different directions, and that they find the pace of work hectic and relentless (Rice, Sorcinelli, and Austin 2000). Many new faculty members, and graduate students aspiring to be faculty members, are expressing concern about what they perceive to be increasing expectations for higher levels of productivity. The often report feeling pulled in many directions simultaneously and wonder whether they can find workable ways to manage their personal and professional responsibilities. (Gappa et al., 2007)

All faculty members, but especially new tenure-track faculty, face multiple demands on their time as well as high expectations for their accomplishment in teaching, research and service. Their time at work is fragmented among diverse and conflicting priorities: students expect 
excellent faculty performance in the classroom: senior colleagues seek these new colleagues' participation in departmental, campus, and professional service; and new tenure-track faculty members simultaneously must produce research and scholarly work. (Gappa et al., 2007) Consequently, the total hours which full-time tenure-track faculty work weekly at their institutions have increased. The average work week for full-time tenure-track faculty across all disciplines has increased from 51 hours in 1988 to 56 hours in 2003 at research universities, from 46 to 53 at comprehensive institutions, and from 41 to $5 \odot$ at all other institutions. (Gappa et al., 2007) The percentage of faculty members reporting that they work more than 55 hours a week has grown from 13 percent in 1972 to 47 percent in 2003. (Gappa et al., 2007) While these figures indicate the increasing workload of faculty overall, the problem is considered particularly acute at business schools, where a shrinking supply of professors are often pulled in many different directions as they are asked to teach more classes, conduct more research, and become more involved with students and business communities.(Fairbank et al., 2005)

The negative impact of these increased work demands on the family and personal lives of faculty members is indicated by the survey data in Figure 51. The top two sources of stress among faculty members relate to lack of time available for either personal activities or household responsibilities. 
Figure 51. Top Sources of Stress among Faculty Members, Compared by Gender

\begin{tabular}{|l|c|c|}
\hline Source of Stress & Males & Females \\
\hline Lack of Personal Time & $68.5 \%$ & $81.9 \%$ \\
\hline $\begin{array}{l}\text { Management of Household } \\
\text { Responsibilities }\end{array}$ & $68.0 \%$ & $81.8 \%$ \\
\hline Teaching Load & $61.6 \%$ & $70.8 \%$ \\
\hline Committee Work & $54.7 \%$ & $61.1 \%$ \\
\hline Tenure review/Promotion Process & $40.3 \%$ & $50.8 \%$ \\
\hline
\end{tabular}

Source: Page 109 of Ref 208

In other survey work, finding enough time to do their work was one of the most frequently mentioned sources of stress among early-career faculty in a range of institutional types (Rice, Sorcinellie, and Austin, 2000). Some graduate students and new faculty, as they observe the stress and long hours that characterize the work lives of their senior colleagues, have expressed uncertainty about wanting to continue pursuing their academic careers.(Gappa et al., 2007)

The academic career therefore is paradoxical. Despite its advantages of independence and flexibility, it is psychologically difficult. The lack of ability to limit work, the tendency to compare oneself primarily to the exceptional giants in one's field, and the high incidence of overload make it particularly difficult for academics to find a satisfactory integration of work with private life. It is the unbounded nature of the academic career that is the heart of the problem. Time is critical for professors, because there is not enough of it to do all the things their job requires: teaching, research, and institutional and professional service. It is therefore impossible for faculty members to protect other aspects of their lives, 
and work tends to dominate. These factors help to explain why 31 percent of faculty are considering work outside the academy (Lindholm et al., 2005) (Gappa et al., 2007) 


\section{SUBSTITUTES}

Perhaps the number one area of graduate management education that will see revisions in the years ahead is the curriculum itself, with an emphasis on offering increased flexibility through expanded programs.(Fairbank et al., 2005) The idea is that with more options available to choose from, students will be enticed by the opportunity to design their own educational experience by selecting courses that interest them. This is in direct opposition to the old model of taking a course load that has already been designed by the school. This new strategy has been the primary tactic for lower-tier schools seeking a competitive advantage against the larger schools. Now, even top-ranked schools recognize the validity in the strategy and are scrapping the "one-size-fits-all" model in favor of the new customizable models that emphasize flexibility and individuality.(Lavelle \& Lehman, 2006) According to a 2004 survey by AACSB International, about 300 business schools were planning either to add academic programs or substantially revise their curricula. More than 50 schools had already made revisions.

The origins of the MBA industry are rooted in a time when communications technology was much more limited than it is today. The limitations of technology necessitated that post-graduate education take place on campus and physically in the presence of the faculty. Today, technology and buyer demand have evolved to provide educational options that were not available in the past. These options have a direct affect on the market for postgraduate education and are valid substitutes for 
traditional business schools. As one source noted, "The industry is no longer monolithic. Business education is delivered in a fragmented market-place and in multiple formats." (AACSB, 2002)

Traditional university-based business schools account for only a fraction of the broad management education industry.(AACSB, 2002) Filling MBA seats has become more difficult as students have more and more MBA choices. (Bisoux, 2006) The number of applications to traditional full-time programs decreased at 78 percent of business schools in the 2002-2003 and 2003-2004 academic years, according to the Graduate Management Admissions Council.(Pulley, 2006) Across the industry it is becoming more apparent that, more and more, students have rigorous and demanding work and family schedules that require the need for more creative program alternatives in terms of scheduling and content. (Bisoux, 2006)

There are many forms of education or training that might be considered as substitutes to the traditional residential MBA program. A review of current literature published by trade magazines, accreditation reports and weekly periodicals points to executive programs, corporate universities, and non-traditional business schools (part time, satellite campuses or online) as the substitutes that claim the biggest share of prospective MBA students.

\section{A. CORPORATE UNIVERSITIES}

Corporate Universities were once thought of as glorified training departments. They have evolved to become much more strategic in focus and are key contributors in helping the parent organization achieve 
goals through education. The corporate university exists to accomplish the following objectives: teach topics like leadership and
communication to executives; standardize skills and knowledge for certain jobs within the company; help the company as a whole develop a unified culture; and develop strong networks among employees."(Shinn, 2004b)

Achieving these objectives in support of corporate strategy requires an education-based approach as opposed to training based approach.

In a survey of 2,570 employees, 64 percent say their company provides some type of in-house training for educational/career development.(GMAC, ) of the over 1600 companies nationwide that have instituted their own version of corporate universities, many have implemented the robust curricula necessary to educate rather than train. A sampling of course offerings include: Industry Trends, Customers and Competitors, Business Strategies, Best Practices, Creative Problem Solving and Leadership Development. The educational philosophy, as employed by the corporate university, tailors the curricula to provide only courses of value to the company's objectives.

Corporate Universities now pose an important threat to traditional management and business schools.(Gary, 1998) The threat implied is that employers can streamline education and training to provide the company specific need-to-know information. While this may not provide the 127 
well rounded education that a traditional business school could provide, it satisfies corporate requirements without the increase in salary that an MBA would command and allows the employee to train at the company's convenience.

Traditional business schools have taken this threat seriously. Many, in fact, have changed strategies to account for this threat. A common example of strategy change to remain competitive is diversification, which is being achieved through partnerships. These partnerships capitalize on the combination of business industry knowledge, which is a stalwart of the b-school curricula, and the specific educational needs that corporations need to advance their strategic goals. MBA providers have even begun to partner themselves with corporations in designing company specific MBAs or other training courses. In essence these partnerships "lean out" the traditional MBA process by identifying the value stream and providing only the subject matter in which the company finds value.

\section{B. NON-TRADITIONAL}

This category includes methods of delivery such as $E$ learning and non-resident MBA. American MBA programs are challenged with the plethora of options available to prospective students. MBA programs are proliferating in other parts of the world, part-time programs are increasing in popularity, and online programs have proven remarkably alluring. (Greenbaum, 2006)

These programs tend to be more accommodating to working professionals and students with scheduling needs. (Syed, 2006) Non-traditional schools such as University of Phoenix and Webster provide the majority of their education 
through satellite campuses and online offerings. They distribute learning to those who might not otherwise have sought postgraduate education. The convenience of their offerings almost certainly siphons off some students from traditional business schools. Moreover, these providers argue that their accreditation makes their degree as valuable as any other accredited school. In addition, the convenience of local campuses and Internet courses can, for some prospective students or employers, outweigh the reputation of traditional business schools.

Part-time MBA programs at AACSB member schools in the U.S. (excluding executive MBA programs and distance education programs) represent 58 percent of these schools' MBA program enrollment.(AACSB, 2002) This statistic illustrates the appeal of non-traditional delivery methods. It is logical to assume that this 58\% represents both potential students of full-time residential business schools as well as students who might not otherwise have pursued an MBA. The power and appeal of non-traditional delivery methods provide opportunities for traditional schools to diversify to remain competitive. With the infrastructure already in place (faculty, curriculum, facilities, etc.) many traditional schools discovered that diversifying to offer part time programs is essential to retain the necessary revenue to continue operations. Recent statistics show that more than 48 percent of American Business schools now offer online MBAs.(Economist Staff, 2004)

The trend to diversify in methods of education delivery has been necessary. Consider that upstarts such as the Universities of Phoenix and Webster both have annual 
enrollments of around 4,000 and 7,000 full and part-time MBA students, respectively.(AACSB, 2002) In 1999, the University of Phoenix awarded 3,473 business master's degrees at 11 U.S. campuses and another 1,430 through its online arm.(AACSB, 2002) The national presence gained by University of Phoenix in just a few years, and in spite of its detractors, has built market capital of more than $\$ 13$ billion and established more than 140 campuses. (Westerbeck, 2004) These types of success stories in the nontraditional market will continue to erode the enrollment of the traditional schools who fail to find strategies that allow them to compete.

\section{EXECUTIVE EDUCATION}

Executive Education provides a heading to capture both degree and non-degree granting programs that are aimed at mid-career professionals. Both are similar to nontraditional programs in that they are accommodating to working professionals and may provide more flexibility than traditional school offerings. These programs provide yet another substitute that potential traditional MBA students may consider.

\section{Degree Granting Executive Education}

These are accredited curricula administered by degree granting institutions that cater to mid-career professionals. The time requirement is less than that of a traditional MBA. One of the key differences between executive and traditional full-time programs, however, is the limited or lack of opportunity to specialize in an executive program. (Syed, 2006)

Given that these Executive MBAs (or EMBAs) target midcareer individuals, it is not surprising that these 130 
programs attract older students.(Syed, 2006) The average age of executive education applicants is 34.3 year old.

\section{Non-Degree Granting Executive Education}

This training does not lead to accreditation but does teach valuable skills. The trade off is between having employees learn a skill to keep them current in a dynamic environment or to facilitate their progression in the company hierarchy. Helping the students learn a skill will enable them to remain current in the respective field and may even give them an advantage in career advancement.

\section{CONCLUSION}

It is fair to ask if the value of a traditional MBA may have slipped in the opinions of some employers. Increased supply of alternate methods of higher education points to evidence that this may be true. The increased availability of substitutes could not be sustained if demand did not increase at a comparable rate.

There is, however, a scenario that might offer a counter to this perspective. It may simply be that the demand for resident graduate business education has remained constant (with adjustments for population increases) and the demand for substitutes is created mostly among customers who would not have pursued a traditional MBA in the first place.

Either way, statistics show that nontraditional programs attract the vast majority of MBA enrollments in the U.S. In the 2003-2004 academic year, only 24 percent of MBA enrollments at AACSB-member schools in the U.S. were in traditional two-year programs. In 2004-2005, that number slipped to slightly more than 21 percent. Enrollment in 
part-time evening and weekend MBA programs ticked up to 63.7 percent in 2004-2005 from 61.2 percent in 2003-2004. (Bisoux, 2006)

Because substitutes draw students from traditional programs, the traditional programs have had to diversify by assimilating attributes of the substitutes to remain competitive. Traditional b-schools now recognize the revenue generating potential of adding part time and executive programs to their offerings. Part-time programs also help schools achieve cost efficiency and prevent competitors from stealing market share.(Fairbank et al., 2005)

While there are conditions that illustrate the competition for the same prospective student between the traditional and non-traditional school, there is also evidence that they are sometimes after different customers. An analysis of GMAT data by GMAC revealed that the average age of part time applicants is 29 years old with an average GMAT score of 490. Full time applicants average 26 years of age with an average GMAT score of 540. (Syed, 2006)

This same survey, however, found evidence of some overlap in the target customer base. In particular, $34 \%$ of respondents who considered a full time two-year traditional MBA program also considered a full time one year accelerated program, $16 \%$ considered a part time program, $10 \%$ considered an EMBA program, and $7 \%$ considered an online/distance-learning program.(MBA.com, 2005a)

There are full time (traditional) universities that have no incentive to diversify. They are fully capable of remaining competitive on reputation and published rankings 
while selling to a student demographic which values the opportunity to be fully immersed and take advantage of program offerings such as career services (including campus interviews), career counseling, social and professional clubs, and other "campus life" events, like an executive speaker series. (Syed, 2006)

However, mid-tier traditional business schools have already started diversifying to include part time and on line offerings. Catering to this market and claiming a portion of the prospective students that don't have the option of full-time education is a must for some schools to remain competitive in today's market.

Figure 52 shows that full-time MBAs incur large opportunity costs associated with leaving the full-time workforce for nearly two years. Consequently, their total costs are large $(\$ 146,725)$ compared to the part-time $(\$ 33,726)$ and executive programs $(\$ 37,293)$. Thus, the ROI is much higher for part-time and executive graduates and the payback period is much shorter.(Holtom \& Inderrieden, 2006) As seen in Figure 53, however, MBA graduates who attended part-time or executive MBA programs are less likely to rate the value of their degree as "outstanding" when compared to graduates who earned their MBA from fulltime programs. 
Figure 52. Impact of Program Type

\begin{tabular}{|l|c|c|c|}
\hline \multicolumn{1}{|c|}{ Variable } & Full-Time & Part-Time & Executive \\
\hline Pre-MBA Salary & $\$ 49,329$ & $\$ 57,301$ & $\$ 77,609$ \\
\hline Post-MBA Salary & $\$ 78,221$ & $\$ 78,287$ & $\$ 91,026$ \\
\hline Total Cost & $\$ 146,725$ & $\$ 33,726$ & $\$ 37,293$ \\
\hline Net Increase in Salary & $\$ 28,892$ & $\$ 20,986$ & $\$ 13,417$ \\
\hline Percent Increase in Salary & $59 \%$ & $37 \%$ & $17 \%$ \\
\hline $10-Y e a r$ Gain from MBA & $\$ 362,228$ & $\$ 263,110$ & $\$ 168,217$ \\
\hline Return on Investments (R0I) & $147 \%$ & $680 \%$ & $351 \%$ \\
\hline Annualized R0I & $15 \%$ & $68 \%$ & $35 \%$ \\
\hline Payback Period (years) & 5.1 & 1.6 & 2.8 \\
\hline
\end{tabular}

Figure 53. Overall Value of the MBA Degree, by Program Type

\begin{tabular}{|c|c|c|c|}
\hline Response & $\begin{array}{c}\text { Full-Time } \\
(n=2, \odot 48)\end{array}$ & $\begin{array}{l}\text { Part-Time } \\
(n=533)\end{array}$ & $\begin{array}{l}\text { Executive } \\
(n=215)\end{array}$ \\
\hline Outstanding & $27 \%$ & $13 \%$ & $23 \%$ \\
\hline Excellent & $34 \%$ & $30 \%$ & $35 \%$ \\
\hline Good & $25 \%$ & $36 \%$ & $29 \%$ \\
\hline Fair & $9 \%$ & $14 \%$ & $8 \%$ \\
\hline Poor & $5 \%$ & $7 \%$ & $5 \%$ \\
\hline Total & $100 \%$ & $100 \%$ & $100 \%$ \\
\hline
\end{tabular}

Typically, almost two-thirds of part-time MBA students are receiving some form of financial subsidy from an employer, according to a 2000 survey by AACSB International and Educational Benchmarking, Inc.(Fisher, 2002) 


\section{E. ANALYSIS}

As the requirement for business knowledge expands, the opportunity for participants to enter the market expands. Most new participants will not enter the market to directly challenge industry leaders. They will enter the market to offer very specific or focused offerings that appeal to sub-sets of traditional school's potential students. The substitute offerings may be inferior in quality and provide less benefit than what a traditional school offers. However, less quality or inferior product does not mean less value.

Buyers will evaluate trade-offs between the convenience of acquiring a product that is "good enough" and the rigid constraints of an education that might be overkill. Substitutes that offer these types of trade-offs are becoming more relevant and are finding niches in the market that draw students away from traditional institutions.

The ways that traditional business schools deal with substitutes is critical to their survival. As upstarts deliver business education through the Internet or satellite campuses, or provide a unique training that enhances business skills of employees, there becomes less of a potential student pool. Traditional business schools have for the most part, dealt with substitutes in three ways: ignore, straddle or switch.

Some of the top-ranked business schools have little need to worry about substitutes. The power of the brands at top schools such as wharton or Harvard suggests very little threat from an online school. Only Harvard has a license to sell Harvard degrees, and Harvard has no 
intention of mass-producing MBAs. Consumer demand for the "Harvard brand MBA" will always outpace the supply. University of Phoenix or local corporate universities are not in the market for Harvard MBA seekers.

The same threat to mid and lower tier schools, however, is real. The online and distance learning schools target the same students that would otherwise attend these schools. The lower tiered schools often have to diversify their offerings or "straddle." This means that they would continue to offer traditional education but would expand to offer alternative distribution methods to maintain a student population that can sustain operations.

Traditional business schools may even exercise the option to challenge the substitutes in their own market. If a school were to find that continuation of traditional business school services were not profitable (or sustainable), changing strategy to deliver education through an alternate means would be a viable option. As students demand more flexibility and fewer can afford the two-year hiatus to attend school, traditional business schools can find their pool of potential full time students too shallow to support the weight of a bricks and mortar operation. While the buildings and classrooms of a traditional school might become excess property, the core competencies of teaching and research are still valuable commodities that can be sold through alternate distribution channels such as distance learning or online services.

Substitutes are a factor that traditional business schools must address. Non-traditional methods can siphonoff potential students to the point that an exclusive fulltime residential program cannot sustain itself by 
traditional means. Traditional schools have to understand the threat of substitutes to their position in the market. This understanding will provide the direction for future strategy in an attempt to remain relevant and continue operations. 
THIS PAGE INTENTIONALLY LEFT BLANK 


\section{ANALYSIS, CONCLUSIONS, AND RECOMMENDATIONS}

\section{A. ANALYSIS OF GSBPP IN RELATION TO THE MBA MARKET ANALYSIS}

One of the drawbacks that the GSBPP faces is the fact that the MBA industry is driven by reputation. Reputation is driven by rankings in the various publications cited in Chapter 3. Rankings are driven by student and faculty preferences, recruiter and employer preferences, admission standards, GMAT scores, and graduates' salaries, just to name a few criteria. However, the underlying factor in each of these categories is that the schools that dominate the Top 20 in rankings from year-to-year are the programs that have been around for quite a long time and have "ambassadors," if you will, that champion the name of the program in the real world.

For example, the business world has been exposed to many Harvard MBAs that have collectively established the reputation of the Harvard Business School as a quality MBA program. This draws more students to apply because they feel the Harvard MBA will get them whatever it is they want (more money, access to a new career, and so on). In turn, Harvard now has a broader range of students to choose from. So, they are able to pick more of the high-caliber students and less of the low-caliber students. Consequently, the students do better because they started out more qualified.

Then Harvard MBA graduates go out in the business world and excel, not necessarily because of the Harvard MBA, but because they were high-caliber to begin with. Regardless of why they succeed, the fact is that they do and this further bolsters the reputation of the Harvard 
Business School because the rest of the world doesn't see these students' credentials prior to going to Harvard. All the world sees is that these Harvard MBAs are excelling. So now the demand for Harvard MBAs goes up because businesses want them. So, more students apply to the Harvard Business School and the cycle repeats itself.

Unfortunately, for the non-ranked or new schools, the reverse is true. Fewer high-caliber and more low-caliber students (probably those that got rejected from the higherranked schools) attend the non-ranked or new schools. So, they have less to choose from and one can draw conclusions where it goes from there. The impact of MBA program reputations creates both a "virtuous cycle" and "vicious cycle" at the same time.

So, for the GSBPP, which only initiated the MBA in 2002 and only had its first graduating class in 2003, it faces a difficult task if it aims to break into the Top 20 or even top 50 rankings. Because it is still in its introductory stages, there haven't been a lot of the "ambassadors" out there from GSBPP who can carry the banner of the school and who can vouch for the quality of the program.(Trevino, Lertangtam, \& Viera, 2004) This, coupled with the fact that there is no GMAT requirement for admissions, and the fact that only military officers (U.S. or foreign) and DoD civilians can attend, does not bode well for the hope of ever being ranked highly (or for qualifying for these rankings at all).

The fact that the GSBPP has been successful in gaining accreditation is a step in the right direction. Unfortunately, there are too many things out of the realm of its control to ever gain access into the upper echelon 
of the MBA elite, at least in terms of rankings. The accreditation serves more to validate its graduates and entice officers to choose the GSBPP over civilian schools when choosing to pursue an MBA, than it does to compete with other MBA programs.

The GSBPP also faces budgetary constraints that most other programs do not face. As noted previously, most universities understand that tuition only covers a fraction of the costs of running the MBA program. They rely on additional funding from sources such as endowments from alumni, donations, government subsidies, and executive MBA programs, consulting fees, and research funding. The endowments constitute the bulk of the supplemental income. The only limit on this additional funding is the generosity of the alumni. Thus, if a program needs additional funding to expand, they can organize a fund raising drive and offer to name buildings after alumni and whatnot.

The GSBPP, on the other hand, is to a large degree constrained to its portion of the overall budget at NPS, and the NPS budget is constrained by what the DoN allocates and what the other services provide in terms of tuition. They also have access to research funding, but since the majority of the research projects are for the DoD, the pool of money that the funds providers possess is limited as well. The DoD does not have the same access to capital resources as IBM. So, research funding is constrained as well.

Most noticeably, however, is the lack of sizeable endowments from alumni. Beyond the NPS Foundation, a large pool of funds from philanthropic alumni doesn't exist to provide steady funding for GSBPP, or NPS for that matter. 
If the GSBPP wants to expand the programs it offers, there are very limited channels that it can access to alleviate funding shortfalls. Thus, the GSBPP cannot be expected to compete on the same level as the dominant MBA programs.

Another burden facing the GSBPP is the competition for renowned professors that also assist in making a name for the MBA program. As pointed out previously, demand for faculty is up and so is the price. Unfortunately, due to the congressional cap on what GSBPP can pay professors, it falls out of the realm of competitiveness for faculty salaries at the Associate Professor and Assistant Professor ranks. With the additional stresses that the strong local economy put on faculty members, especially in the housing market, it further limits the pool of applicants to those who are uniquely interested in defense-focused research or those who love the Monterey area.

The defense-focused niche also limits the applicant pool of professors. When young professors are hired to the GSBPP, there is no guarantee of acceptance on the tenure track. So, prior to being approved for the tenure track, a professor must conduct a certain amount of research in the defense area. With no guarantee of acceptance or of tenure once accepted onto the tenure track, there is little incentive to perform DoD-relevant research. This is for the simple reason that faculty are leery of being pigeonholed as a defense-focused professor by the broader academic community.

A professor gains credibility in his/her discipline based on the research he or she conducts and publishes in that discipline. If junior faculty members primarily conduct defense-focused research that is loosely tied, at 
best, to their discipline during the early years of their careers and they do not get tenure from the GSBPP, they stand the chance of either being seen as an outsider from the mainstream academic community or at least being behind the power curve at their next place of employment. Thus, incentives do not match up between all professors and the GSBPP defense-focused MBA niche that is desired.

Lastly, in regards to what the GSBPP can do to curtail the threat of substitutes, it is doing all that it can. By branching out into distance education, GSBPP is taking full advantage of the constraints it faces. As mentioned in the Chapter 6 analysis, there are basically three basic avenues to address the threat of substitutes. You can stop doing what you do and start doing only what the substitutes do, you can do both (called straddling), or you can ignore the substitutes and focus on what you're already doing.

Given the constrained resources and how the GBSPP falls under the NPS mission, dropping the resident MBA and focusing only on distance learning or executive education would not be feasible. Because of how the GSBPP is geographically isolated from operating bases, offering a part-time MBA is not feasible either. There is no large pool of officers in the local area that can attend night classes or weekend classes, and since only officers can attend, civilians can't come here at night or on the weekends to take courses either. You have to be stationed in Monterey to have access to the GSBPP and you have to be accepted into the full-time resident MBA program to get stationed here.

To focus solely on the resident MBA is not the right approach either. Due to the geographical isolation of NPS, 
there are students who desire to earn an MBA, but do not have access to the GSBPP. So, instead of ignoring them and, consequently, forcing them to seek a MBA from competitors, the smart avenue is to reach out to them through distance education. Ignoring them would only hurt the image of the GSBPP. For an infant program seeking distinction, turning away students who desire to participate in the MBA program offered is a poor strategy.

Trying to break into executive education is another smart move. Currently executive education at NPS is taught primarily at the center for Continuing Education (CCE). The CCE is located in the same building as the GSBPP yet, as of now, there is no direct affiliation with the GSBPP faculty, although moves are being made to incorporate GSBPP influence into the CCE. This effort would expand GSBPP's avenues for funding as well as its overall reputation without incurring too much additional cost.

\section{B. CONCLUSIONS}

Unlike other disciplines, business schools are torn between two market realities: they must provide academic value to their campus communities and meet the demands of business for more immediate corporate training.(Bisoux, 2004) Graduate education is not about training, yet early-career employers often want exactly this. This speaks of trade-offs. The GSBPP is not immune to this contradiction of desires. Officers want an MBA that will educate them in a way that will create future opportunities for them whether they are in the military or private sector. Faculty members want to teach them how to innovate with new ideas and be creative at problem solving. Both focus on the "big picture" and on the students' future 
application of their graduate education. On the contrary, the services want officers that can step in immediately and create value in a certain billet, with minimal future focus.

The question of how to bridge this divide is one that is causing controversy in the MBA industry. For the GSBPP, however, the niche strategy of being a defense-focused MBA has served to satisfy both parties. By offering the typical MBA curriculum that is accredited, officers get what they want in an MBA education. The professors get to teach their students how to think analytically and critically and apply proven problem solving techniques in ambiguous situations. By making the courses defense-focused and offering certain specialized courses, the services get what they want in officers prepared to go out and make an immediate impact. By offering the distance education, the GSBPP is able to reach officers that desire to attend NPS but cannot for some reason or another. The GSBPP functions, in many respects, as the DoD's corporate university.

This niche strategy that the GSBPP has adopted is a reasonable strategy for competing in the MBA industry. When considering the constraints that the GSBPP faces in regards to inability to compete in the rankings game, the students that are allowed attend, the cost constraints that it faces, and the ability to face the threats of substitutes, there are few other viable options.

\section{RECOMMENDATIONS}

The most significant limitation that the defensefocused niche places on the GSBPP is in terms of the faculty. In today's market of increased demand for faculty 
due to the dwindling amount of doctoral professors, salary becomes an important incentive to attract professors. As already noted, the GSBPP is constrained in its ability to be competitive in salaries that it offers to senior professors. This is due to congressional ceilings. Perhaps the most important incentive valued by faculty is freedom. The original intent of the alternating quarters for teaching and researching was designed to provide the faculty enough freedom to focus on research without being bogged down by teaching requirements. Unfortunately, not being fully staffed has heaped additional teaching requirements onto the already full laps of the faculty, while the limited supply and scope of available research funding has constrained the true academic freedom that faculty enjoy when they are not required to teach.

The one recommendation that this paper offers is to initiate a thorough investigation on ways to improve the salary, incentive package, or a combination of the two that is offered to professors. This would entice proven faculty to seek a tenure-track position with the GSBPP and attract proven faculty from other schools who would otherwise be put off by the lack of salary incentive.

The other aspect of this investigation should be to see what could be done to revamp the instruction/research scheduling system in order to unburden the faculty and allow them more time to conduct general academic research. This would be another aspect that would entice current faculty to stay and attract new faculty that normally would not have been interested. 


\title{
APPENDIX
}

Adopted: April 25, 2003

Revised: January 01, 2004

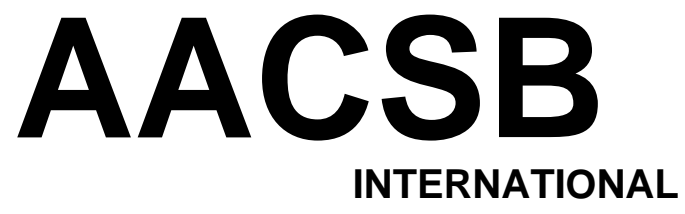

Revised: January 01, 2005

Revised: January 01, 2006

\section{Eligibility Procedures and Accreditation Standards for Business Accreditation}

\author{
AACSB International - The Association
} to Advance Collegiate Schools of Business

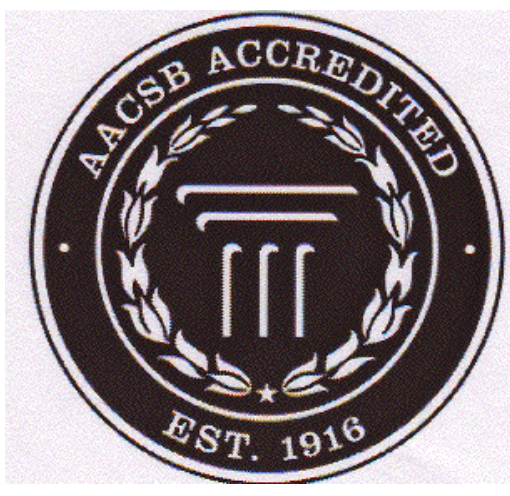

777 South Harbour Island Blvd., Suite 750, Tampa, FL 33602-5730 USA

Tele: 1-813-769-6500 Fax: 1-813-769-6559 Web: http://www.aacsb.edu 
EXCERPTS FROM SECTION 2 (pages 13-17):

STANDARDS FOR BUSINESS ACCREDITATION

STRATEGIC MANAGEMENT STANDARDS

1: The school publishes a mission statement or its equivalent that provides direction for making decisions. [MISSION STATEMENT]

2: The school's mission statement is appropriate to higher education for management and consonant with the mission of any institution of which the school is part. The mission includes the production of intellectual contributions that advance the knowledge and practice of business and management. [MISSION APPROPRIATENESS]

3: The mission statement or supporting documents specify the student populations the school intends to serve. [STUDENT MISSION]

4: The school specifies action items that represent high priority continuous improvement efforts. [CONTINUOUS IMPROVEMENT OBJECTIVES]

5: The school has financial strategies to provide resources appropriate to, and sufficient for, achieving its mission action items. [FINANCIAL STRATEGIES]

\section{PARTICIPANTS STANDARDS}

6: The policies for admission to business degree programs offered by the school are clear and consistent with the school's mission. [STUDENT ADMISSION]

7: The school has academic standards and retention practices that produce high quality graduates. [STUDENT RETENTION]

8: The school maintains a staff sufficient to provide stability and ongoing quality improvement for student support activities. [STAFF SUFFICIENCY-STUDENT SUPPORT]

9: The school maintains a faculty sufficient to provide stability and ongoing quality improvement for instructional programs offered. [FACULTY SUFFICIENCY] 
10: The faculty has, and maintains, intellectual qualifications and current expertise to accomplish the mission... [FACULTY QUALIFICATIONS]

11: The school has well-documented and communicated processes in place to manage and support faculty members over the progression of their careers consistent with the school's mission, to include:

- ...the expectations the school holds for them on all mission-related activities.

- Providing orientation, guidance and mentoring.

- Undertaking formal periodic review, promotion, and reward processes.

- Maintaining overall plans for faculty resources.

[FACULTY MANAGEMENT AND SUPPORT]

12: The business school's faculty...share responsibility to:

- Ensure adequate time is devoted to learning activities...

- Ensure adequate student-faculty contact...

- Set high expectations for academic achievement...

- Evaluate instructional effectiveness and overall student achievement.

- Continuously improve instructional programs.

- Innovate in instructional processes.

[AGGREGATE FACULTY AND STAFF EDUCATIONAL RESPONSIBILITY]

13: Individual teaching faculty members:

- Operate with integrity in their dealings with students and colleagues.

- Keep their own knowledge current with the continuing development of their teaching disciplines.

- Actively involve students in their learning process.

- Encourage collaboration and cooperation among participants.

- Ensure frequent, prompt, feedback on student performance.

[INDIVIDUAL FACULTY EDUCATIONAL RESPONSIBILITY]

14: Individual Students: 
- Operate with integrity in their dealings with faculty and other students.

- Engage the learning materials with appropriate attention and dedication.

- Maintain their engagement when challenged by difficult learning activities.

- Contribute to the learning of others.

- Perform to standards set by the faculty.

[STUDENT EDUCATIONAL RESPONSIBILITY]

ASSURANCE OF LEARNING STANDARDS

15: Management of Curricula: The school uses welldocumented, systematic processes to develop, monitor, evaluate, and revise the substance and delivery of the curricula of degree programs and to assess the impact of the curricula on learning.

The standard requires use of a systematic process for curriculum management but does not require any specific courses in the curriculum.

Normally, the curriculum management process will result in undergraduate and master's level general management degree programs that will include learning experiences in such management-specific knowledge and skills areas as:

- Ethical and legal responsibilities in organizations and society.

- Financial theories, analysis, reporting, and markets.

- Creation of value through the integrated production and distribution...

- Group and individual dynamics in organizations.

- Statistical data analysis and management science...

- Information technologies as they influence the structure and processes of organizations and economies...

- Domestic and global economic environments of organizations.

- Other management-specific knowledge and abilities as identified by the school.

[MANAGEMENT OF CURRICULA] 
18: Master's level degree in general management (e.g., MBA) programs: Knowledge and skills...Learning at the master's level is developed in a more integrative, interdisciplinary fashion than undergraduate education.

The capacities developed through the knowledge and skills of a general master's level program are:

- Capacity to lead in organizational situations.

- Capacity to apply knowledge in new and unfamiliar circumstances through a conceptual understanding of relevant disciplines.

- Capacity to adapt and innovate to solve problems, to cope with unforeseen events, and to manage in unpredictable environments.

[MASTER'S LEVEL GENERAL MANAGEMENT LEARNING GOALS]

20: The master's level degree programs must provide sufficient time, content coverage, student effort, and student-faculty interaction to assure that the learning goals are accomplished. [MASTER'S EDUCATIONAL LEVEL] 
THIS PAGE INTENTIONALLY LEFT BLANK 


\section{LIST OF REFERENCES}

AACSB. (2006a). 2005-2006 salary survey executive summary.

AACSB. (2006b). AACSB guide to business education.

AACSB. (2003). Sustaining scholarship in business schools.

AACSB. (2002). Management education at risk report to the management education task force to the AACSBinternational board of directors.

AACSB. (1998). Is a real shortage looming? doctoral faculty demand edges upward again. [Electronic version]. AACSB International.

Bisoux, T. (2006). Flex time for the MBA. BizEd, (July/August), 22.

Bisoux, T. (2004). Balancing the B-school budget. BizEd, May/June.

Briley, D. A. (1997). The Ph.D. project: The marketing of business school faculty diversity. Graduate School of Business, Stanford University.

Chronicle. (2007). Earned degrees conferred 203-4.

[Electronic version]. The Chronicle of Higher Education, $53(1)$.

Chronicle. (2006). The Faculty. The Chronicle of Higher Education [Electronic version], 52, 27, A12.

Committee on Issues in Management Education. (2005). Why management education matters: Its impact on individuals, organizations, and society. Committee on Issues in Management Education Task Force on The Value Proposition for Management Education.

Conley, M. (2002). How corporate needs shape the B-school student body. Selections: The Magazine of the Graduate Management Admission Council, 2, 1, 14.

Dobni, D., \& Dobni, B. (1996). Canadian business schools: Going out of business? Journal of Education For Business, September/October, 28. 
Dulek, R. E. (1992). Why fight the system? the non-choice facing beleaguered business faculties - business schools. [Electronic version]. Business Horizons, September-October.

Economist Staff. (2004). But can you teach it? business schools. The Economist, May 22.

Edgington, R., \& 0lkin, J. (2002). The 'who' in who gets in. Selections: The Magazine of the Graduate Management Admission Council, 2(1) 8.

Ehrenberg, R. E., \& Zhang Liang. (2004). Do tenured and tenure track faculty matter?.

Fairbank, J. F., Labianca, G., and Leclair, D. (2005). Forecast. BizEd, May/June.

Fields, D. M. (2006). Perfect storm. BizEd, January/February.

Fisher, C. (2002). The economy stumbles and applications surge. Selections: The Magazine of the Graduate Management Admission Council, 2(1) 18.

Gappa, J. M., Austin, A. E., \& Trice, A. G. (2007). Rethinking faculty work. San Francisco: Jossey-Bass.

Gary, L. (1998). Corporate universities: The new pioneers of management education. an interview with Jeanne Meister. Harvard Management Update.

GMAC. (2006a). Corporate Recruiters Survey: March 2006, general data report Graduate Management Admission Council.

GMAC. (2006b). Global MBA graduate survey 2006. general data report.

GMAC. (2006c). MBA alumni perspectives survey: April 2006 comprehensive data report. Graduate Management Admission council.

GMAC. (2006). MBA alumni perspectives survey. Graduate Management Admissions Council.

Greenbaum, S. (2006). B-school critics miss the mark. BizEd, July/August. 
Holtom, B. C., \& Inderrieden, E. J. (2006). Examining the value added by graduate management education (No. RR-0616) Graduate Management Admission Council.

Hunt, S. C. (2004). Business faculty job selection:

Factors affecting the choice of an initial position. Journal of Business and Management, 10, 1, 53.

Lathroum, J. A. (1998). A comparative analysis of graduate management education.

Lavelle, L., \& Lehman, P. (2006, The best B-schools of 2006. [Electronic version]. Business Week, 4006, 54.

LeClair, D. (2004). The professor's paycheck. BizEd, March/April.

Mast, C. (2002). The art of admissions. Selections: The Magazine of the Graduate Management Admission Council, 2(1) 23.

Mast, C. (2001). The people behind the rankings. Selections: The Magazine of the Graduate Management Admission Council, 1(2) 16.

MBA.com. (2005a). MBA.com registrants survey.

MBA.com. (2005b). MBA.com registrants survey comprehensive data report. October 2005 Graduate Management Admission Council.

Montauk, R. (2002, Should you invest in an MBA? [Electronic version]. College Journal from the Wall street Journal.

Murray, M. (2006). MBA salary No. RR-06-13) Graduate Management Admission Council.

Olkin, J. M. (2004). Informed sources. Selections: The Magazine of the Graduate Management Admission Council, 4(1) 8.

Policano, A. J. (2005, What price rankings? BizEd, (September/0ctober) 26.

Pulley, L. (2006, An RX for the ailing MBA. BizEd, January/February. 
Schmotter, J. W. (2004). A world of difference. Selections: The Magazine of the Graduate Management Admission Council, 4(1) 3.

Schoenfeld, G., \& Bruce, G. D. (2005). School brand images and brand choices in MBA programs No. RR-05-10)Graduate Management Admission Council.

Shinn, S. (2005). How to hire. BizEd, November/December, 38 .

Shinn, S. (2004a). Big payoffs. BizEd, May/June.

Shinn, S. (2004b) The B-school at company. BizEd, May/June, 32 .

Sutton, T. P., \& Bergerson, P. J. (2001). Faculty compensation systems: Impact on the quality of higher education. ERIC digest. ERIC Clearinghouse on Higher Education.

Syed, S. (2006). GMAC curriculum variation in MBA programs No. RR-06-03.

Thornton, S. (2006). The devaluing of higher education.

Trevino, R. L., Lertangtam, I., \& Viera, N. (2004).

Marketing plan for the naval postgraduate school master of business administration to the navy unrestricted line community.

Tyson, G. (2003).Deans talk about dollars. Selections: The Magazine of the Graduate Management Admission Council, 24.

Tyson, G. (2004). Management and the media. Selections: The Magazine of the Graduate Management Admission Council, $4(1), 17$.

Tyson, G. (2002). Beyond cognitive testing. Selections: The Magazine of the Graduate Management Admission Council, $2(1), 31$.

Tyson, G. (2001). A look behind the numbers. Selections: The Magazine of the Graduate Management Admission Council, 1(2), 8 .

Westerbeck, T. (2004). Brave new world, bold new B-school. BizEd, July/August. 
Wikipedia. (2007). Tenure. Retrieved 3-14-07, http://en.wikipedia.org/wiki/Tenure.

Wuorio, J. (2001). The impact of the rankings: Multiple perspectives. Selections: The Magazine of the Graduate Management Admission Council, 1(2), \28.

Zimmerman, J. (2001). Can American business schools survive? Bradley Research Policy Center. 
THIS PAGE INTENTIONALLY LEFT BLANK 


\section{INITIAL DISTRIBUTION LIST}

1. Defense Technical Information Center

Ft. Belvoir, Virginia

2. Dudley Knox Library

Naval Postgraduate School

Monterey, California 